\title{
‡USGS
}

science for a changing world

In cooperation with the U.S. Army Corps of Engineers and the San Antonio River Authority

Simulation of Streamflow and Water Quality in the Leon Creek Watershed, Bexar County, Texas, 1997-2004

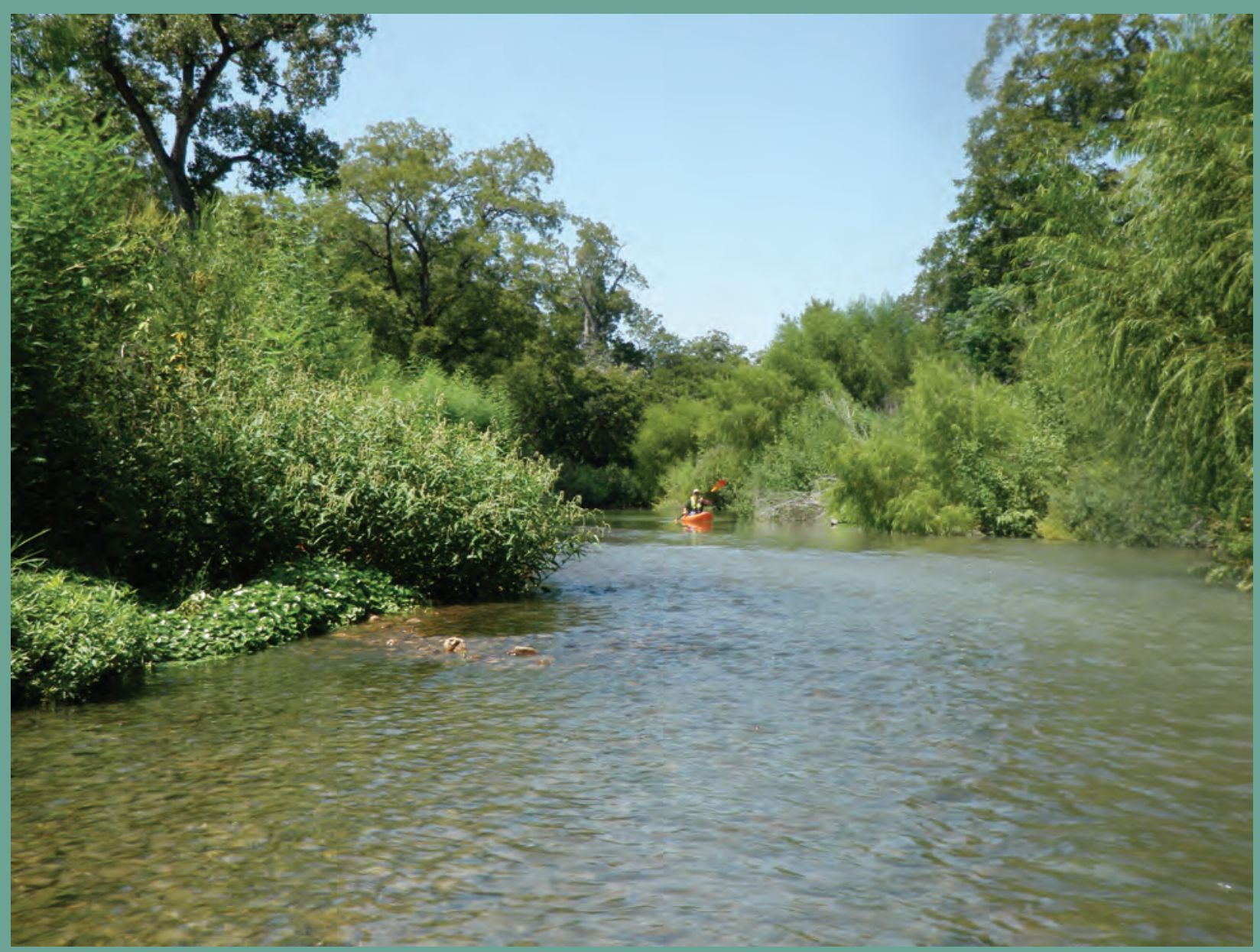

Scientific Investigations Report 2009-5191 
Front and back cover:

Leon Creek near confluence of the Medina River, looking upstream, August 26, 2009. 


\section{Simulation of Streamflow and Water Quality in the Leon Creek Watershed, Bexar County, Texas, 1997-2004}

By Darwin J. Ockerman and Meghan C. Roussel

In cooperation with the U.S. Army Corps of Engineers and the San Antonio River Authority

Scientific Investigations Report 2009-5191 


\section{U.S. Department of the Interior \\ KEN SALAZAR, Secretary}

\section{U.S. Geological Survey Suzette M. Kimball, Acting Director}

U.S. Geological Survey, Reston, Virginia: 2009 This and other USGS information products are available at http://store.usgs.gov/
U.S. Geological Survey
Box 25286 , Denver Federal Center
Denver, CO 80225
To learn about the USGS and its information products visit http://www.usgs.gov/
1-888-ASK-USGS

Any use of trade, product, or firm names is for descriptive purposes only and does not imply endorsement by the U.S. Government.

Although this report is in the public domain, permission must be secured from the individual copyright owners to reproduce any copyrighted materials contained within this report.

Suggested citation:

Ockerman, D.J., and Roussel, M.C., 2009, Simulation of streamflow and water quality in the Leon Creek watershed, Bexar County, Texas, 1997-2004: U.S. Geological Survey Scientific Investigations Report 2009-5191, 50 p. 


\section{Contents}

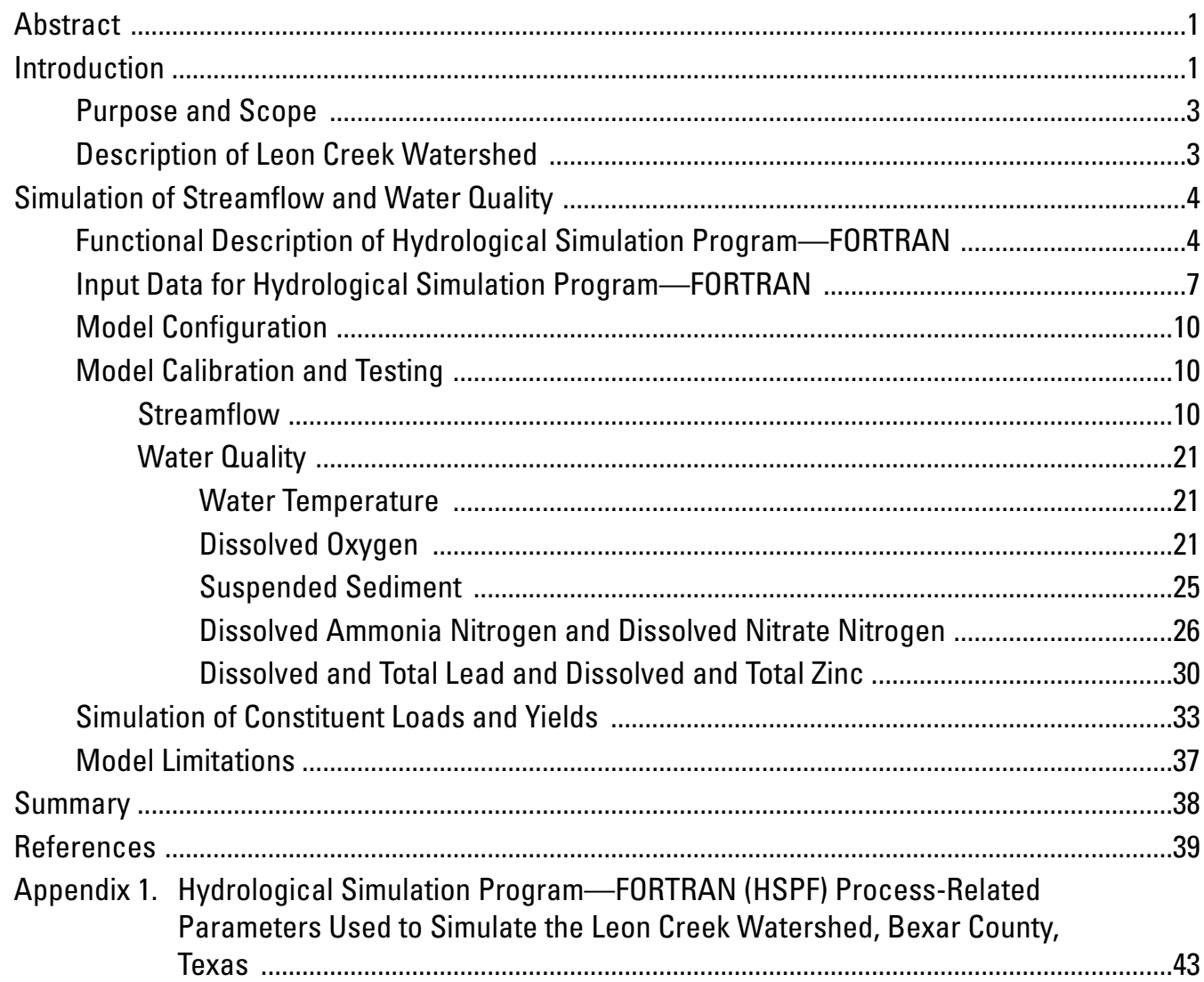

\section{Figures}

1. Map showing location of Leon Creek watershed, Bexar County, Texas ...........................2

2. Map showing land use in the Leon Creek watershed, Bexar County, Texas, 2004 ...........5

3. Diagram showing Hydrological Simulation Program-FORTRAN (HSPF) flowchart for $(A)$ impervious and $(B)$ pervious land segments

4. Map showing data-collection sites that provided data for Hydrological Simulation Program-FORTRAN model of the Leon Creek watershed, Bexar County, Texas ...........8

5. Map showing delineated subwatersheds for the Hydrological Simulation Program-FORTRAN model of the Leon Creek watershed, Bexar County, Texas

6-12. Graphs showing:

6. Measured and simulated daily mean streamflow at station 08180945 Leon Creek at Scenic Loop Road near Leon Springs, Texas, 2001-04

7. Measured and simulated daily mean streamflow at station 08181050 Leon Creek at Prue Road at San Antonio, Texas, 2001-03

8. Measured and simulated daily mean streamflow at station 08181480 Leon Creek at Interstate Highway 35 at San Antonio, Texas, 2001-04

9. Measured and simulated daily mean water temperature at station 08181480 Leon Creek at Interstate Highway 35 at San Antonio, Texas, 1997-2000 
10. Measured and simulated daily mean dissolved oxygen at station 08181480 Leon Creek at Interstate Highway 35 at San Antonio, Texas, 1997-2000

11. Relation between daily mean streamflow and daily suspended-sediment load based on 20 streamflow-concentration data pairs for station 08181480 Leon Creek at Interstate Highway 35 at San Antonio, Texas, 1992-2007

12. Relation between estimated monthly suspended-sediment loads and Hydrological Simulation Program-FORTRAN-simulated suspendedsediment loads for station 08181480 Leon Creek at Interstate Highway 35 at San Antonio, Texas, 2001-04

\section{Tables}

1. Data-collection sites that provided data for the Hydrological Simulation Program-FORTRAN model of the Leon Creek watershed, Bexar County, Texas .9

2. Streamflow calibration (five gaging stations) and testing (one gaging station) results for the Hydrological Simulation Program-FORTRAN model of the Leon Creek watershed, Bexar County, Texas

3. Summary of calibrated values for selected hydrology-related parameters for the Hydrological Simulation Program-FORTRAN model of the Leon Creek watershed, Bexar County, Texas

4. Water temperature calibration results for the Hydrological Simulation ProgramFORTRAN model of the Leon Creek watershed, Bexar County, Texas

5. Dissolved oxygen calibration results for the Hydrological Simulation ProgramFORTRAN model of the Leon Creek watershed, Bexar County, Texas

6. Simulated 1992-2004 suspended-sediment runoff concentrations from four pervious and impervious land-use types and 1992-2004 medians of measured suspended-sediment runoff concentrations from watersheds that represent the respective land-use types (sites 8-14) for the Hydrological Simulation ProgramFORTRAN model of the Leon Creek watershed, Bexar County, Texas

7. Measured and simulated suspended-sediment concentrations and loads at upper-watershed sites for selected stormflows for the Hydrological Simulation Program-FORTRAN model of the Leon Creek watershed, Bexar County, Texas

8. Measured and simulated dissolved ammonia nitrogen concentrations and loads at upper-watershed sites for selected stormflows for the Hydrological Simulation Program-FORTRAN model of the Leon Creek watershed, Bexar County, Texas

9. Measured and simulated dissolved nitrate nitrogen concentrations and loads at upper-watershed sites for selected stormflows for the Hydrological Simulation Program-FORTRAN model of the Leon Creek watershed, Bexar County, Texas

10. Measured and simulated concentrations of dissolved ammonia nitrogen and dissolved nitrate nitrogen for selected stormflows at station 08181480 Leon Creek at Interstate Highway 35 at San Antonio, Texas

11. Measured and simulated concentrations of dissolved and total lead at upperwatershed sites for selected stormflows for the Hydrological Simulation Program-FORTRAN model of the Leon Creek watershed, Bexar County, Texas

12. Measured and simulated concentrations of dissolved and total zinc at upperwatershed sites for selected stormflows for the Hydrological Simulation Program-FORTRAN model of the Leon Creek watershed, Bexar County, Texas 
13. Measured and simulated concentrations of total lead and total zinc for selected stormflows at station 08181480 Leon Creek at Interstate Highway 35 at San

Antonio, Texas

14. Summary statistics for measured streamflow and concentrations of total lead and total zinc for nine base-flow samples collected during 1992-94 at station 08181480 Leon Creek at Interstate Highway 35 at San Antonio, Texas

15. Summary statistics for simulated daily mean total lead and total zinc concentrations for base-flow periods at station 08181480 Leon Creek at Interstate Highway 35 at San Antonio, Texas, 1997-2004

16. Summary of calibrated values for selected water-quality parameters for the Hydrological Simulation Program-FORTRAN model of the Leon Creek watershed, Bexar County, Texas, 1997-2004

17. Simulated mean annual streamflow and annual streamflow loads and yields of suspended sediment, dissolved nitrate nitrogen, and total lead at the outlet of Leon Creek watershed, Bexar County, Texas, 1997-2004

18. Simulated mean annual streamflow and mean annual streamflow yields of suspended sediment, dissolved nitrate nitrogen, and total lead at selected stream reach (RCHRES) outlets, Leon Creek watershed, Bexar County, Texas, 1997-2004

\section{Conversion Factors, Datums, and Water-Quality Units}

\section{Inch/Pound to SI}

\begin{tabular}{|c|c|c|}
\hline Multiply & By & To obtain \\
\hline \multicolumn{3}{|c|}{ Length } \\
\hline inch (in.) & 25.4 & millimeter (mm) \\
\hline foot (ft) & 0.3048 & meter $(\mathrm{m})$ \\
\hline mile (mi) & 1.609 & kilometer $(\mathrm{km})$ \\
\hline \multicolumn{3}{|c|}{ Area } \\
\hline acre & 4,047 & square meter $\left(\mathrm{m}^{2}\right)$ \\
\hline square mile $\left(\mathrm{mi}^{2}\right)$ & 2.590 & square kilometer $\left(\mathrm{km}^{2}\right)$ \\
\hline \multicolumn{3}{|c|}{ Volume } \\
\hline acre-foot (acre-ft) & 1,233 & cubic meter $\left(\mathrm{m}^{3}\right)$ \\
\hline \multicolumn{3}{|c|}{ Flow rate } \\
\hline cubic foot per second $\left(\mathrm{ft}^{3} / \mathrm{s}\right)$ & 0.02832 & cubic meter per second $\left(\mathrm{m}^{3} / \mathrm{s}\right)$ \\
\hline gallon per minute (gal/min) & 0.06309 & liter per second (L/s) \\
\hline \multicolumn{3}{|c|}{ Slope } \\
\hline foot per mile ( $\mathrm{ft} / \mathrm{mi})$ & 0.1894 & meter per kilometer $(\mathrm{m} / \mathrm{km})$ \\
\hline \multicolumn{3}{|c|}{ Mass } \\
\hline pound, avoirdupois (lb) & 0.4536 & kilogram (kg) \\
\hline ton, short $(2,000 \mathrm{lb})$ & 0.9072 & megagram $(\mathrm{Mg})$ \\
\hline
\end{tabular}

Temperature in degrees Fahrenheit $\left({ }^{\circ} \mathrm{F}\right)$ may be converted to degrees Celsius $\left({ }^{\circ} \mathrm{C}\right)$ as follows:

${ }^{\circ} \mathrm{C}=\left({ }^{\circ} \mathrm{F}-32\right) / 1.8$ 


\section{Datum}

Horizontal coordinate information is referenced to the North American Datum of 1983 (NAD 83).

Elevation, as used in this report, refers to distance above the vertical datum.

\section{Water-Quality Units}

$\mathrm{mg} / \mathrm{L}$, milligram per liter

$\mu \mathrm{g} / \mathrm{L}$, microgram per liter 


\title{
Simulation of Streamflow and Water Quality in the Leon Creek Watershed, Bexar County, Texas, 1997-2004
}

\author{
By Darwin J. Ockerman and Meghan C. Roussel
}

\section{Abstract}

The U.S. Geological Survey, in cooperation with the U.S. Army Corps of Engineers and the San Antonio River Authority, configured, calibrated, and tested a Hydrological Simulation Program-FORTRAN watershed model for the approximately 238-square-mile Leon Creek watershed in Bexar County, Texas, and used the model to simulate streamflow and water quality (focusing on loads and yields of selected constituents). Streamflow in the model was calibrated and tested with available data from five U.S. Geological Survey streamflow-gaging stations for 1997-2004. Simulated streamflow volumes closely matched measured streamflow volumes at all streamflow-gaging stations. Total simulated streamflow volumes were within 10 percent of measured values. Streamflow volumes are greatly influenced by large storms. Two months that included major floods accounted for about 50 percent of all the streamflow measured at the most downstream gaging station during 1997-2004.

Water-quality properties and constituents (water temperature, dissolved oxygen, suspended sediment, dissolved ammonia nitrogen, dissolved nitrate nitrogen, and dissolved and total lead and zinc) in the model were calibrated using available data from 13 sites in and near the Leon Creek watershed for varying periods of record during 1992-2005. Average simulated daily mean water temperature and dissolved oxygen at the most downstream gaging station during 1997-2000 were within 1 percent of average measured daily mean water temperature and dissolved oxygen. Simulated suspended-sediment load at the most downstream gaging station during 2001-04 (excluding July 2002 because of major storms) was 77,700 tons compared with 74,600 tons estimated from a streamflowload regression relation (coefficient of determination $=.869$ ) . Simulated concentrations of dissolved ammonia nitrogen and dissolved nitrate nitrogen closely matched measured concentrations after calibration. At the most downstream gaging station, average simulated monthly mean concentrations of dissolved ammonia and nitrate concentrations during 19972004 were 0.03 and 0.37 milligram per liter, respectively. For the most downstream station, the measured and simulated concentrations of dissolved and total lead and zinc for stormflows during 1993-97 after calibration do not match particularly closely. For base-flow conditions during 1997-2004 at the most downstream station, the simulated/measured match is better. For example, median simulated concentration of total lead (for 2,041 days) was 0.96 microgram per liter, and median measured concentration (for nine samples) of total lead was 1.0 microgram per liter.

To demonstrate an application of the Leon Creek watershed model, streamflow constituent loads and yields for suspended sediment, dissolved nitrate nitrogen, and total lead were simulated at the mouth of Leon Creek (outlet of the watershed) for 1997-2004. The average suspended-sediment load was 51,800 tons per year. The average suspendedsediment yield was 0.34 ton per acre per year. The average load of dissolved nitrate at the outlet of the watershed was 802 tons per year. The corresponding yield was 10.5 pounds per acre per year. The average load of lead at the outlet was 3,900 pounds per year. The average lead yield was 0.026 pound per acre per year.

The degree to which available rainfall data represent actual rainfall is potentially the most serious source of measurement error associated with the Leon Creek model. Major storms contribute most of the streamflow loads for certain constituents. For example, the three largest stormflows contributed about 64 percent of the entire suspended-sediment load at the most downstream station during 1997-2004.

\section{Introduction}

South-central Texas, including the Leon Creek watershed in Bexar County (fig. 1), is one of the most flash-flood-prone areas of the United States (Bomar, 1995). A large flash flood occurred during October 1998 when as much as 30 inches of rain occurred in a 2-day period in south-central Texas. Thirtytwo lives were lost, and property damage was estimated to be $\$ 500$ million (Slade and Patton, 2003). During the October 1998 flash flood, more than 12 inches of rain fell in parts of the Leon Creek watershed in less than 24 hours. The peak discharge at U.S. Geological Survey (USGS) streamflow-gaging station 08181480 Leon Creek at Interstate Highway (IH) 35 at San Antonio, Tex., exceeded the 100-year recurrence interval (Slade and Persky, 1999). Since the October 1998 flash flood, ongoing development in the Leon Creek watershed and subsequent increase of impervious cover have increased the risk of flood damage.

In the "Texas Water Quality Inventory 2000" (Texas Commission on Environmental Quality, 2002), part of lower Leon Creek (32 river miles of Leon Creek upstream from its confluence with the Medina River) (fig. 1) was identified as impaired on the basis of the criteria of suitability for contact 


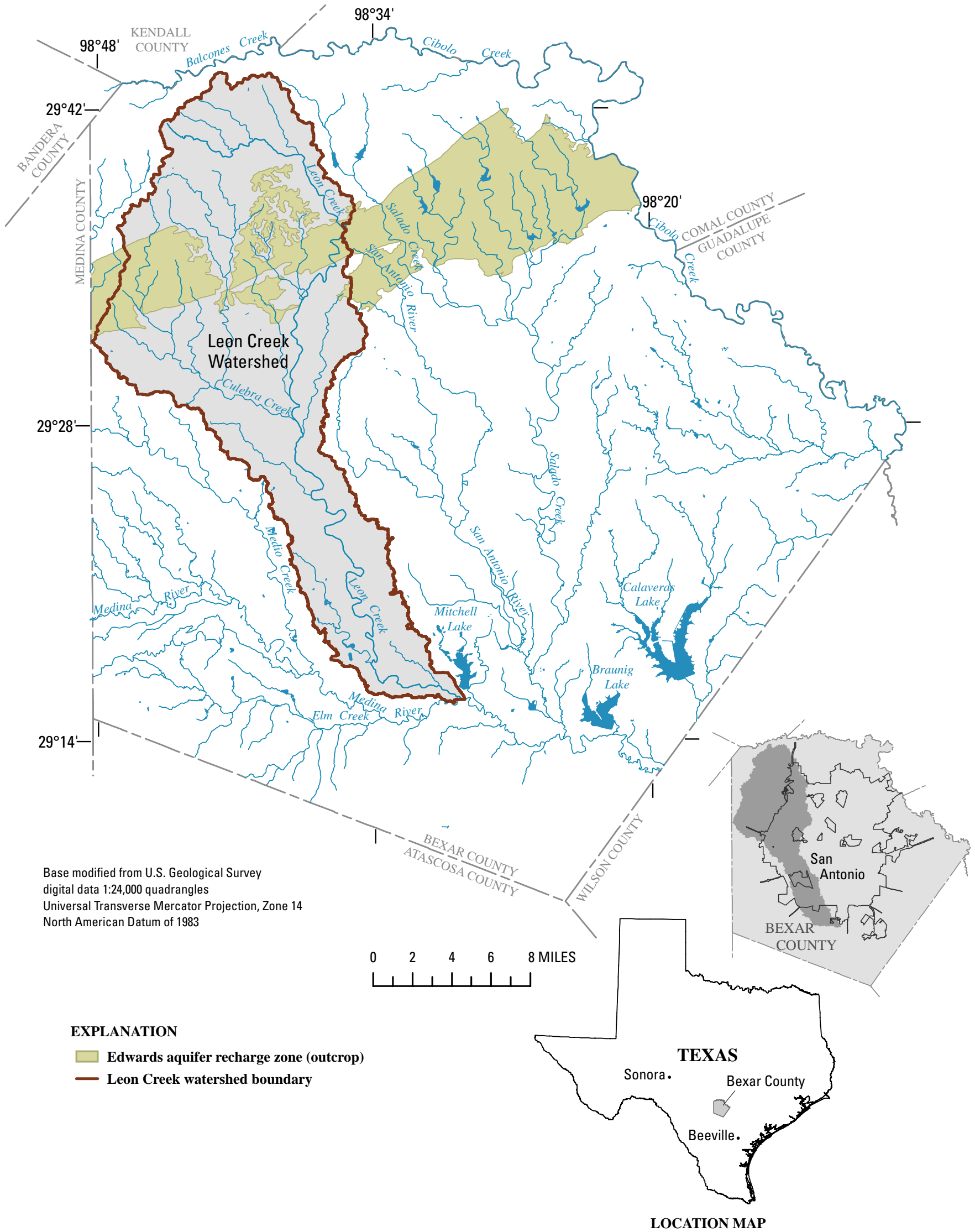

Figure 1. Location of Leon Creek watershed, Bexar County, Texas. 
recreation and sustainability of high aquatic life. Contact recreation use was not supported because of elevated fecal coliform counts. Aquatic life use was only partially supported because of depressed dissolved oxygen concentrations. In 2004, the Texas Commission on Environmental Quality (2005) also determined that sections of lower Leon Creek did not support fish consumption because of high levels of polychlorinated biphenyls.

In 2004, the U.S. Army Corps of Engineers (USACE), Fort Worth District, began a study of water-resource issues in the Leon Creek watershed. The purpose of that study (U.S. Army Corps of Engineers, 2004) is to (1) establish and document the existing hydrologic, engineering, economic, and environmental conditions for the watershed (phase 1), and (2) evaluate best-management practices for flood-risk management, improvement in water quality, and ecosystem restoration (phase 2). As part of phase 1, the USGS, in cooperation with the USACE and the San Antonio River Authority (SARA), configured, calibrated, and tested a watershed model for the Leon Creek watershed and used the model to simulate streamflow and water quality (focusing on loads and yields [load per acre of contributing drainage area] of selected constituents).

The Leon Creek watershed model is configured so that it might be used in potential simulations as part of phase 2 . Potential simulations would involve detention/retention structures, sediment-control structures, and vegetative management practices. Another use of the model is to predict streamflow and water-quality conditions for scenarios involving population increases and associated land development in the watershed. Finally, the modular nature of the watershed model will allow for the configuration, calibration, and simulation of water-quality constituents not included in the simulations reported here.

\section{Purpose and Scope}

The purpose of this report is to describe simulation of streamflow and water quality in the Leon Creek watershed using a watershed model, the Hydrological Simulation Program-FORTRAN (HSPF model) (Bicknell and others, 2001), with input data collected during 1997-2004. The HSPF model for this application was configured to simulate streamflow, water temperature, dissolved oxygen, suspended sediment, dissolved ammonia nitrogen, dissolved nitrate nitrogen, and dissolved and total lead and zinc. The HSPF model and the input data are described first and then the process of configuration, calibration, and testing of the model. Following that is description of an application of the model involving simulation of loads and yields of suspended sediment, dissolved nitrate nitrogen, and total lead; and finally, discussion of the limitations on the application of the model to the Leon Creek watershed. The report documents the contributions of the USGS as part of phase 1 of the USACE study of water-resource issues in the Leon Creek watershed.

\section{Description of Leon Creek Watershed}

The Leon Creek watershed is in western Bexar County in the greater San Antonio area (fig. 1). Leon Creek originates in northwestern Bexar County and runs south-southeast for about 57 river miles to its confluence with the Medina River. The drainage area of the Leon Creek watershed (at the confluence with the Medina River) is about 238 square miles. The watershed is in a region described as having a subtropical, sub-humid climate characterized by hot summers and mild, dry winters (Larkin and Bomar, 1983). Average monthly low temperatures range from 38.6 degrees Fahrenheit $\left({ }^{\circ} \mathrm{F}\right)$ in January to $74.0^{\circ} \mathrm{F}$ in July; average monthly high temperatures range from $62.1^{\circ} \mathrm{F}$ in January to $94.7^{\circ} \mathrm{F}$ in August (National Climatic Data Center, 2009). Average annual rainfall in the watershed is about 33 inches per year based on 1971-2000 rainfall data from the National Weather Service station at the San Antonio International Airport. During 1942-2008, daily rainfall greater than 0.01 inch occurred, on average, 76 days per year (National Climatic Data Center, 2009). Daily rainfall 1.0 inch or greater occurs at the San Antonio International Airport about every 43 days according to Asquith and Roussel (2003, table 5, sequence number 1047). Most rainfall tends to occur in spring, early summer, and fall, but abundant rainfall can occur anytime during the year (Larkin and Bomar, 1983).

Four predominant geologic formations or groups of formations crop out in the watershed: From north to south according to the San Antonio sheet of the "Geologic Atlas of Texas" (Brown and others, 1983), the surficial rocks primarily are (1) Glen Rose Limestone; (2) Edwards Group undivided; (3) Navarro Group and Marlbrook Marl, Pecan Gap Chalk, and Austin Chalk; and (4) Leona Formation and fluviatile terrace deposits. The outcropping Glen Rose Limestone is characterized by shallow, rocky, and clayey soils with relatively low to moderate infiltration capacity based on the Bexar County Soil Survey (U.S. Department of Agriculture, Soil Conservation Service, 1966). The outcropping Edwards Group undivided is characterized by shallow- to moderate-depth clayey soils with relatively high infiltration largely because of faults, sinkholes, and other karst features. The outcropping Navarro Group and Marlbrook Marl, Pecan Gap Chalk, and Austin Chalk are characterized by deep clayey soils with moderate infiltration capacity. The outcropping Leona Formation and fluviatile terrace deposits are characterized by deep clayey and sandy loam soils with relatively high infiltration.

The recharge zone (outcrop) of the Edwards aquifer crosses the northern part of the watershed (fig. 1). Numerous wells tap the Edwards aquifer, most of which are concentrated in the confined freshwater zone of the aquifer (the watershed south of the outcrop). Many wells in the confined freshwater zone can yield more than 1,000 gallons per minute (Maclay, 1995, p. 43). Although the Edwards aquifer supplies water for several major springs in the region, no major springs are in the Leon Creek watershed. Also, Leon Creek streamflow in the area upstream from and on the Edwards aquifer recharge zone outcrop is intermittent, flowing only for a short period (days 
or weeks) during and after abundant rainfall. Streamflow on the recharge zone is lost to faults, fractures, and other geologic features, and streamflow losses on the recharge zone contribute directly to Edwards aquifer recharge (Puente, 1978). Most recharge to the Edwards aquifer occurs as streamflow losses. Direct infiltration of rainfall through soil and rock layers (diffuse recharge) is a relatively small part of the total recharge to the Edwards aquifer (Maclay, 1995). Other than relatively small stock ponds, no lakes or reservoirs are in the study watershed. There is a relatively large municipal wastewater treatment facility (annual discharge of about 39,000 acre-feet during 1997-2004 [M. Veazy, Texas Commission on Environmental Quality, written commun., 2001]) near the mouth of Leon Creek.

Land use in the northwestern part of the Leon Creek watershed is largely undeveloped (rangeland and juniper and oak forest) (fig. 2). Undeveloped land in the southern part of the watershed is largely agricultural. The central area of the watershed includes relatively intense residential and commercial development. Much undeveloped land in the watershed is undergoing conversion to suburban residential and commercial land use. The 2004 population of the watershed was about 278,000 (City of San Antonio, Department of Public Works, 2006). Demographic statistics for all of Bexar County indicate a population increase of about 11 percent during the period represented by the data of this report (1997-2004) (Texas Department of State Health Services, 2008).

Elevation in the Leon Creek watershed ranges from about 460 to 1,930 feet above sea level. Land slopes generally are steeper in the northern (upstream) part of the watershed than in the southern (downstream) part. Overall, the Leon Creek stream channel slope is about 18 feet per mile. Some stream slopes in the northern part of the watershed (upper Culebra Creek and upper Helotes Creek) are greater than 60 feet per mile.

\section{Simulation of Streamflow and Water Quality}

Streamflow and water quality in the Leon Creek watershed were simulated with the Hydrological Simulation Program-FORTRAN (HSPF) (Bicknell and others, 2001). HSPF was selected for the study watershed because it is one of the more comprehensive watershed models available, can simulate a variety of stream and watershed conditions with reasonable accuracy (including water-quality processes), and enables flexibility in adjusting the model to simulate alternative conditions or scenarios (Donigian and others, 1995). To simulate the hydrologic processes that occur in a watershed, HSPF uses data (referred to as parameters in the HSPF documentation) such as the time history of rainfall, air temperature, and other meteorological parameters; parameters related to land cover and land-use practices; and soil characteristics. The result of an HSPF simulation is an output of streamflow and concentrations (or loads) of water-quality constituents at a user-specified interval, or time step. A 1-hour time step was used for this report.

Continuous simulation models facilitate simulation of important watershed processes for a full range in streamflow regime for the simulation period. The relative importance of various processes and factors influencing water quality can vary considerably with the magnitude of streamflow. For example, processes that appreciably affect water-quality conditions during low flows might have relatively minor effects on water-quality conditions during high flows. For assessment of peak-streamflow characteristics, continuous simulation models can provide a more realistic evaluation of antecedent soil-moisture conditions than is generally possible with eventbased models (Martin and others, 2001, p. 66).

\section{Functional Description of Hydrological Simulation Program—FORTRAN}

In HSPF, a watershed is represented by a group of hydrologically similar areas referred to as hydrologic response units (HRUs) that drain to a stream segment, lake, or reservoir referred to as a RCHRES (ReaCH REServoir). Each RCHRES (composed of open or closed channels, or completely mixed lakes) is contained in and corresponds to a subwatershed. HRUs reflect areas in a subwatershed of similar land use, surficial geology, and other factors deemed important to produce a similar hydrologic response to rainfall and potential (pan) evaporation. HRUs are categorized as either pervious or impervious land segments, termed PERLND (PERvious LaND) or IMPLND (IMPervious LaND), respectively. A PERLND is represented conceptually within HSPF by three interconnected water storage zones-an upper zone, a lower zone, and a groundwater zone. An IMPLND is represented by surface storage, evaporation, and runoff processes. The hydraulics of stream reaches is simulated using storage routing (Donigian and others, 1995).

HSPF, a continuous, semi-lumped-parameter model (Singh, 1995), provides continuous water and mass balance by tracking rainfall and water-quality constituents through the conceptual pathways of the hydrologic cycle. HSPF is composed of a series of computational routines that separately simulate processes of the hydrologic cycle. Specifically, HSPF simulates the hydrologic cycle as an interconnected series of storage (and processing) segments with water fluxes (volume per unit area per unit time) and constituent fluxes (mass [weight] per unit area per unit time) moving between the various storages (fig. 3). Storages and fluxes are controlled by system inputs and user-supplied parameter values. For each HRU and RCHRES, the model computes a water budget (inflows, outflows, and changes in storage) for each time step.

HSPF is an empirical model; although some parameters are directly measurable, most are estimated during model calibration (Martin and others, 2001). The HSPF model of the Leon Creek watershed was developed by (1) compiling 


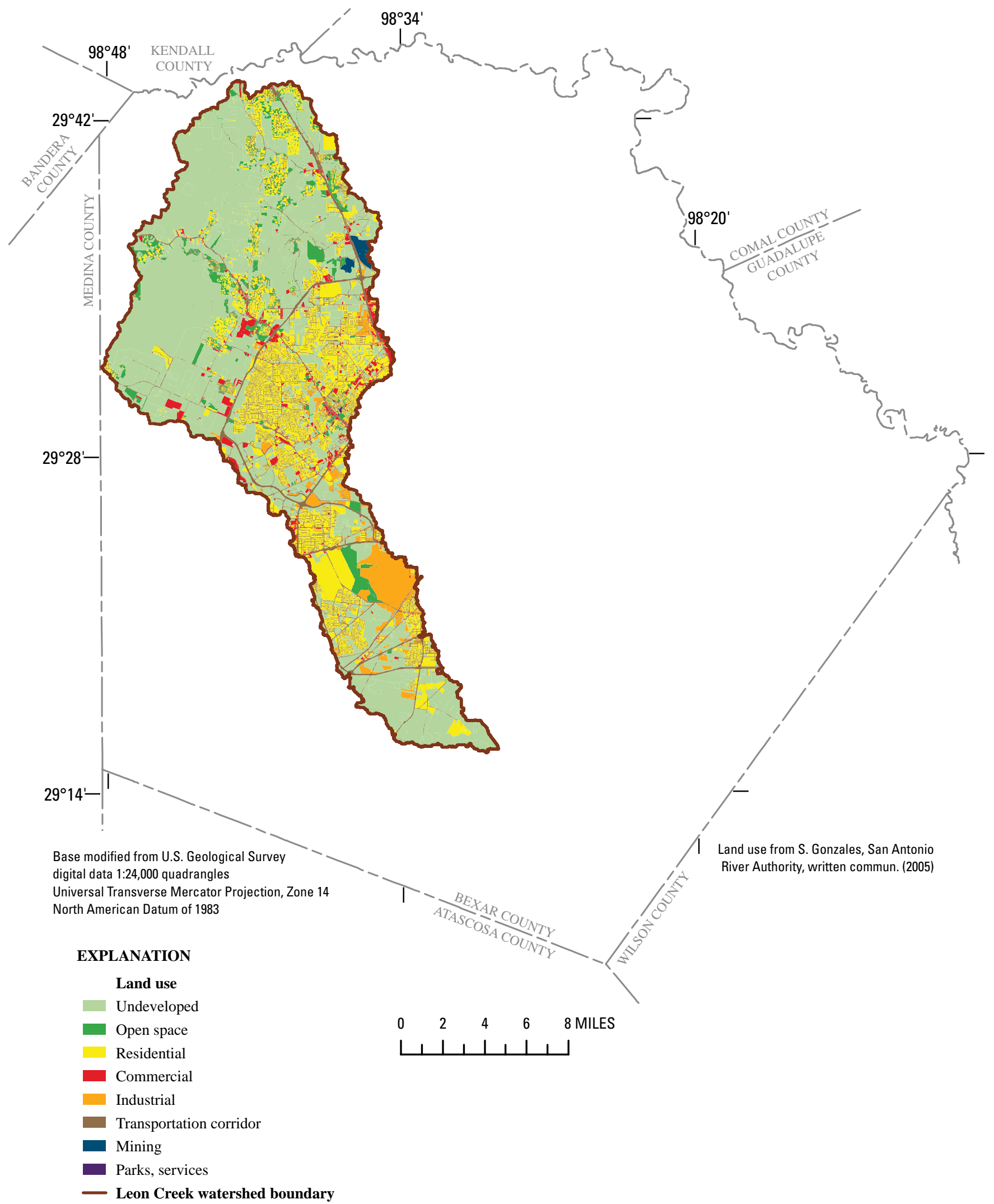

Figure 2. Land use in the Leon Creek watershed, Bexar County, Texas, 2004. 


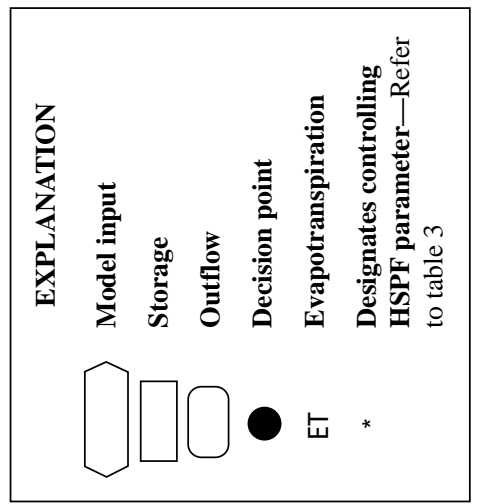

$\dot{m}$

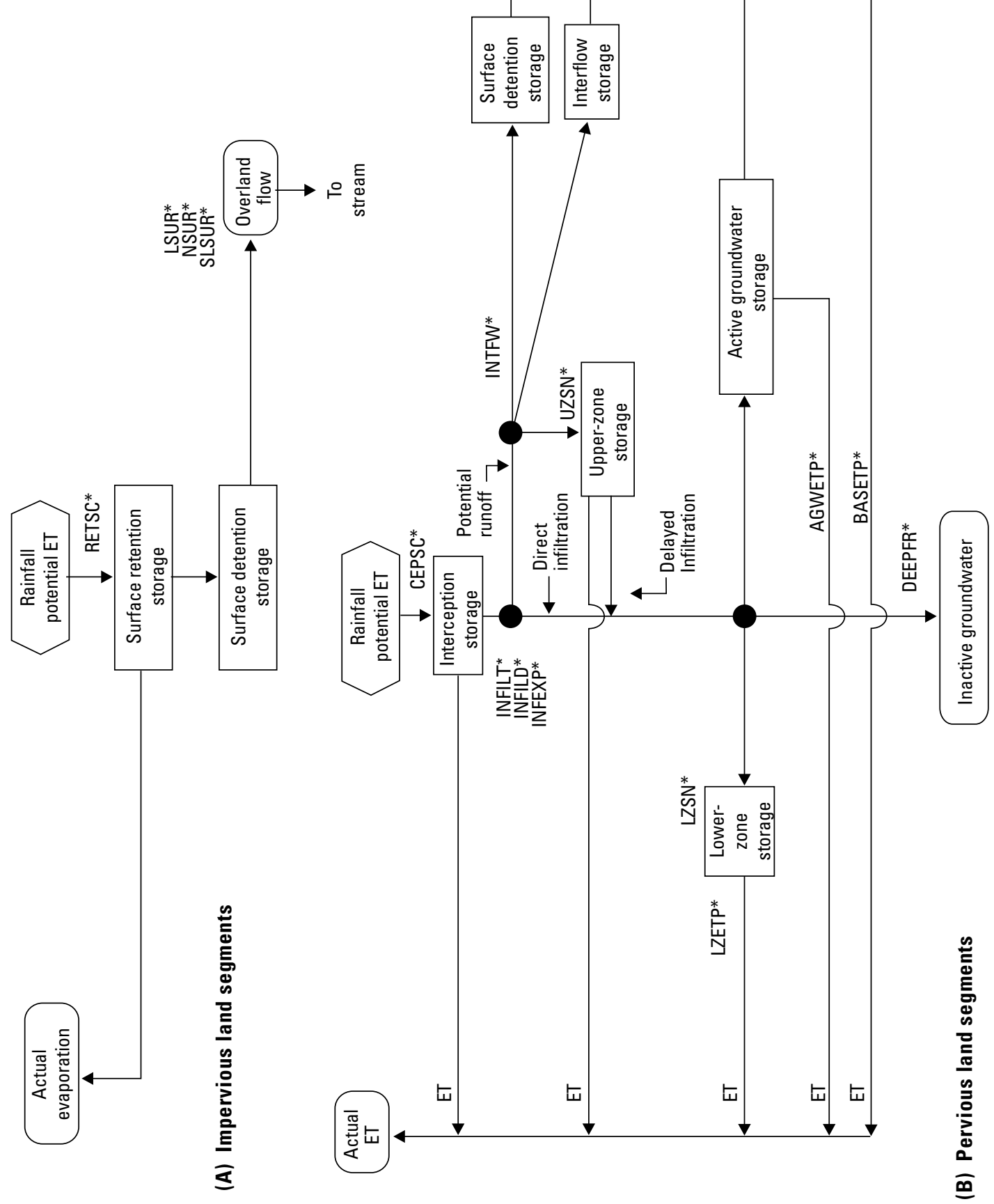


and processing required input data, (2) configuring the model to represent the watershed, and (3) calibrating the model to improve simulation accuracy. A complete description of the computational processes and required input model parameters is provided in the HSPF user's manual (Bicknell and others, 2001). The definitions of the HSPF model process parameters used in the Leon Creek model are listed in appendix 1.

\section{Input Data for Hydrological Simulation Program-FORTRAN}

Input data for the HSPF model include spatial data (land use, topography, geology, and soils), hydraulic characteristics of stream segments (RCHRESs), meteorological data, and streamflow and water-quality data. Spatial data were used to develop model HRUs (PERLNDs, IMPLNDs) and RCHRESs. Watershed land-use data for 2004 are from an engineering consultant report to SARA on the development of land-use information for hydrologic modeling (S. Gonzalez, San Antonio River Authority, written commun., 2005). The consultant report also provided estimates of impervious cover for each land-use category. Topography (slope) was obtained from USGS 7.5-minute digital elevation models (U.S. Geological Survey, 2001). The digital elevation models also were used to delineate subwatersheds as part of the model development. Surface geology was obtained from the San Antonio sheet of the "Geologic Atlas of Texas" (Brown and others, 1983). Soils were obtained from the "Soil Survey of Bexar County, Texas" (U.S. Department of Agriculture, Soil Conservation Service, 1966). Hydraulic characteristics for each stream segment (surface area, volume, and discharge as a function of depth) were estimated from a HEC-RAS model of the Leon Creek watershed developed by the USACE (D. Prochaska, U.S. Army Corps of Engineers, written commun., 2006). As part of its Next Generation Weather Radar (NEXRAD) program, the National Weather Service (NWS) produces gridded rainfall estimates for the region; these estimates are known as stage III data (National Oceanic and Atmospheric Administration, 2006). This spatial rainfall information can be incorporated into watershed models as an improvement to using somewhat sparse rain-gage networks to obtain rainfall data. For the rainfall input to the HSPF model of the Leon Creek watershed, a procedure for combining a gridded NEXRAD rainfall surface with subwatersheds of the Leon Creek watershed was used. A Geographic Information System (GIS) provided standardized functions to accomplish this task.

The NEXRAD stage III product offers rainfall estimates spatially averaged over grid cells of about 16 square kilometers (about 10 square miles) and temporally averaged over 1 hour. In the stage III data product, estimates from one or more radars are combined into a common grid system so that basinwide streamflow forecasts can be made. The radar that provides data for the Leon Creek watershed is the NWS Austin/ San Antonio NEXRAD station (site 1, table 1), located about 40 miles northwest of the Leon Creek watershed. Stage III products provide hourly estimates in the Hydrologic Rainfall Analysis Project (HRAP) grid system, a 4-kilometer (about 2.5-mile) grid in a Polar Stereographic map projection (Shedd and Fulton, 1993). The HRAP grid, as defined by Greene and Hudlow (1982), is used to define the location of each average rainfall value in stage III data. Flat map coordinate systems like HRAP are defined using a datum and a map projection.

Stage III data for 1999-2004 were obtained for the HRAP grid cells that cover the Leon Creek watershed. These hourly rainfall time series were then used to determine Leon Creek watershed average hourly rainfall time series for each subwatershed: The HRAP grid cells were intersected with the predetermined subwatersheds of the Leon Creek model. Hourly values of rainfall associated with each HRAP cell were then averaged on the basis of the area of each HRAP grid cell within each subwatershed. This was done for each subwatershed by weighting the HRAP grid cell hourly rainfall values on the basis of the percentage of subwatershed area covered by each HRAP grid cell using a custom-built, operation-specific PERL script (William H. Asquith, U.S. Geological Survey, written commun., 2006). For example, if 100 percent of an HRAP cell is within a subwatershed, the rainfall values are multiplied by 1 ; if 25 percent of an HRAP cell is within a subwatershed then the rainfall values are multiplied by 0.25 . After the area-weighted hourly rainfall values were determined for each subwatershed, the values were averaged and the averages were compiled into an hourly time series for the subwatershed.

Other meteorological data required for the Leon Creek model simulations comprise air temperature, dew point temperature, wind speed, solar radiation, cloud cover, and evaporation. These data (except evaporation) were obtained from the NWS station at the San Antonio airport (site 2)

(fig. 4; table 1) and were generally available at 3-hour intervals. Daily pan evaporation data were obtained from the NWS station at San Antonio Sea World (site 3). The 3-hour data were disaggregated to hourly rates for each day (on the basis of site latitude and time of year) using a computer program that is part of the BASINS (Better Assessment Science Integrating Point and Nonpoint Sources) watershed modeling software package (U.S. Environmental Protection Agency, 2008).

Continuous streamflow and instream water-quality data (temperature and dissolved oxygen) and discrete water-quality data from analysis of samples were used to calibrate model parameters pertaining to constituent simulations. Streamflow and water-quality data were available for five USGS streamflow-gaging stations in the watershed (sites 4-7, 15) (fig. 4; table 1). Water-quality data also were obtained from other USGS gaging stations in Bexar County (sites 8-14, 16). These data typically were used to help characterize water quality from specific land-use categories.

Discharge data (monthly averages) from the wastewater treatment facility located near the mouth of Leon Creek (site 16) (fig. 4; table 1) were obtained from the Texas Commission on Environmental Quality (M. Veazy, Texas Commission 


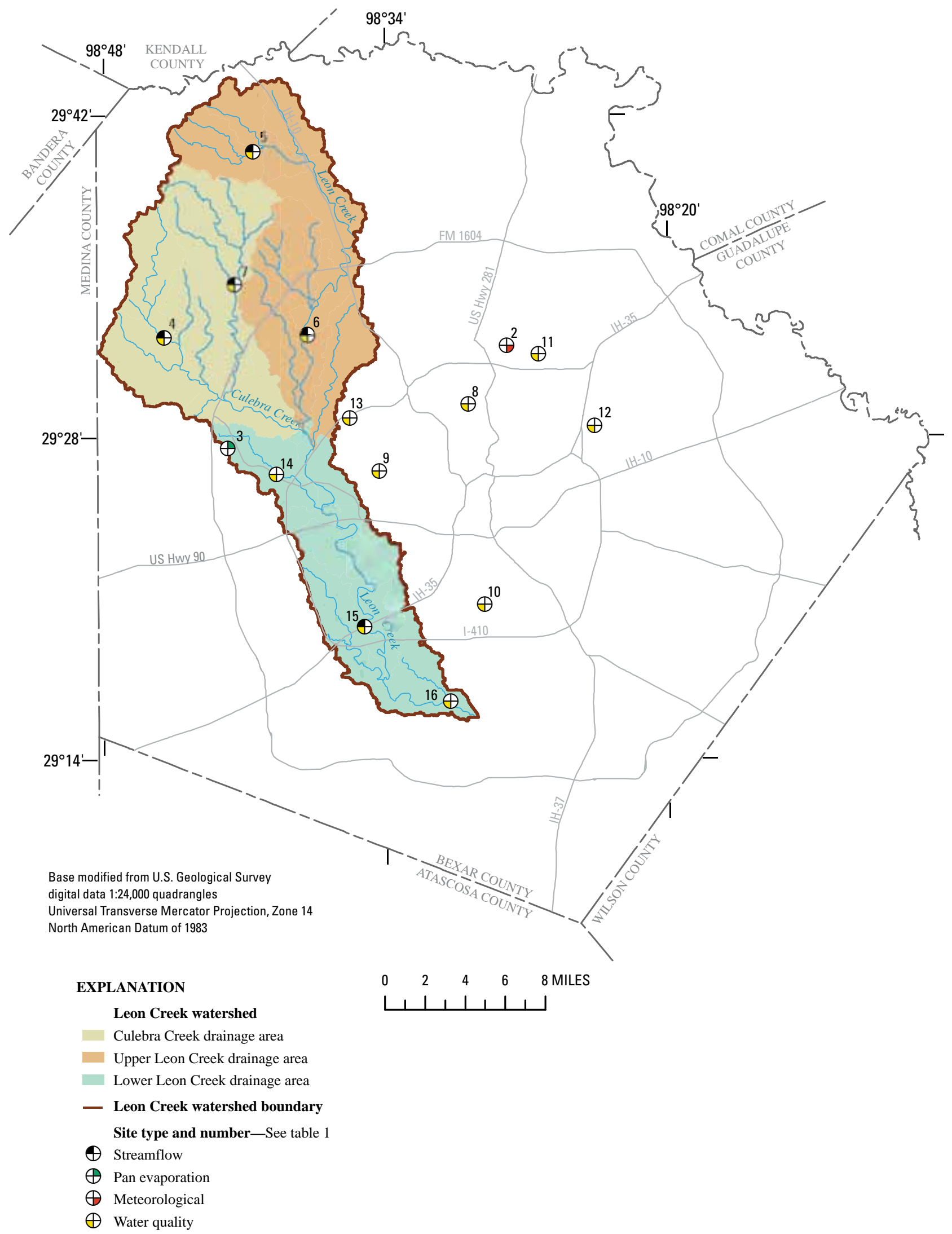

Figure 4. Data-collection sites that provided data for Hydrological Simulation Program—FORTRAN model of the Leon Creek watershed, Bexar County, Texas. 
Table 1. Data-collection sites that provided data for the Hydrological Simulation Program—FORTRAN model of the Leon Creek watershed, Bexar County, Texas.

[ddmmss, degrees minutes seconds; NWS, National Weather Service; --, not available; NEXRAD, Next Generation Weather Radar; USGS, U.S. Geological Survey]

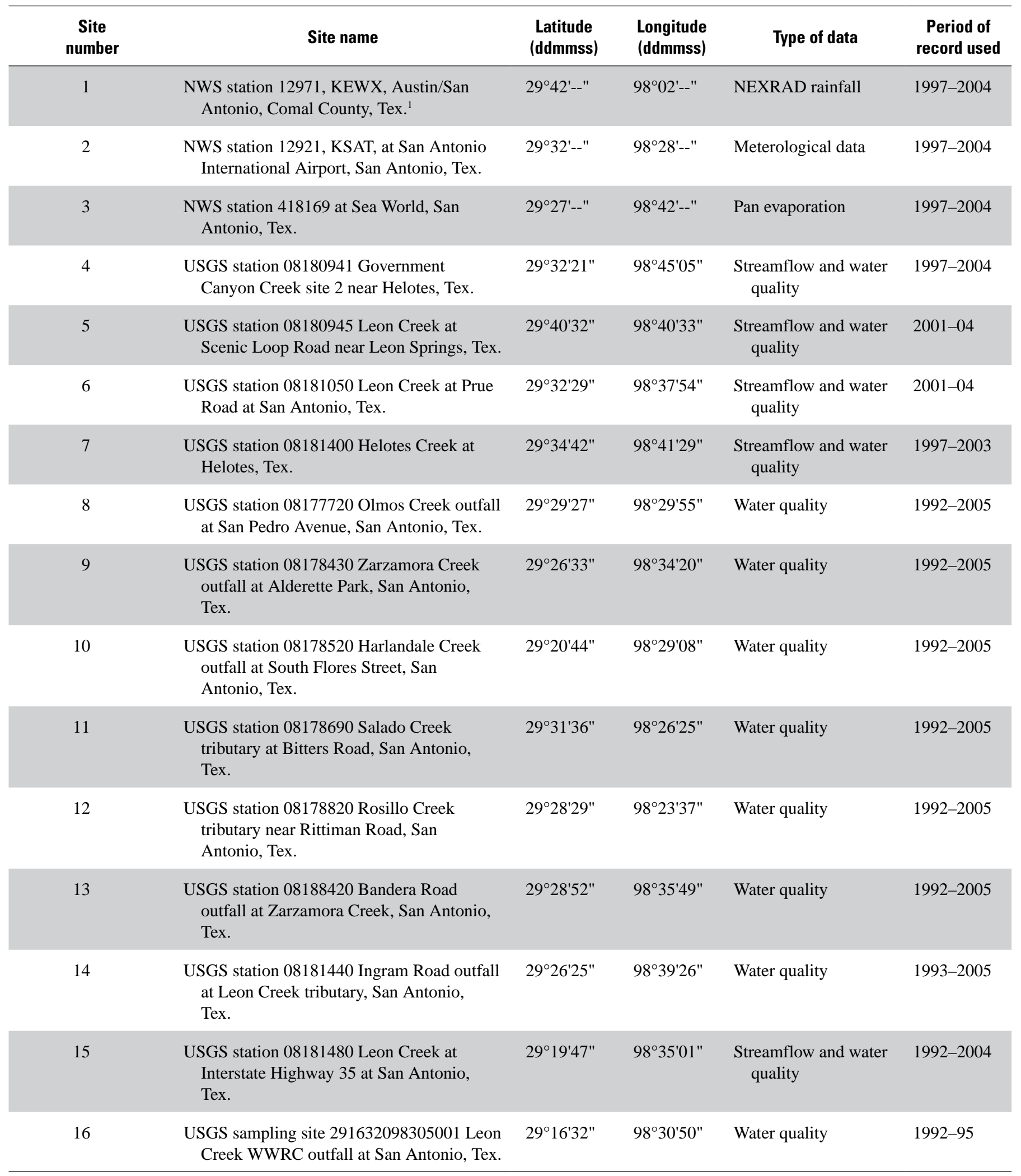

\footnotetext{
${ }^{1}$ About 40 miles northwest of Leon Creek watershed.
} 
on Environmental Quality, written commun., 2001). Water quality of wastewater discharge was obtained from analyses of 131 effluent samples collected from four major wastewater recycling centers that discharge to Leon Creek and the lower Medina and San Antonio Rivers by the USGS during 1992-95 (Ockerman and McNamara, 2003, p. 8 and 31).

\section{Model Configuration}

The HSPF model of the Leon Creek watershed was configured by (1) defining subwatersheds for the Leon Creek watershed; (2) identifying unique HRUs on the basis of combinations of land use, geology and soils, and slope; and (3) determining initial (uncalibrated) values of HSPF process-related parameters. Initial estimates of parameters were obtained primarily from previous studies (Brown and Raines, 2002; Ockerman and McNamara, 2003; and Ockerman, 2005).

Corresponding to each subwatershed is an HSPF stream segment (RCHRES). The stream-segment configuration (fig. 5) was developed with regard to defining segments with (1) similar streamflow travel times that approximate the model time step; (2) homogeneous channel properties such as slope and conveyance; and (3) outlets of subwatersheds at important points such as streamflow-gaging stations, tributary confluence, aquifer recharge-zone boundaries, and withdrawal or discharge sites.

In each subwatershed, PERLND and IMPLND HRUs were categorized on the basis of combinations of three factors: geology-soils, land use, and land slope. The geologysoils factor involves the four predominant formation outcrops or groups of outcrops and the soil types of each as described in the "Description of Leon Creek Watershed" section. The Glen Rose Limestone, characterized by shallow, rocky, and clayey soils, occurs in all or part of subwatersheds 10, 12, 14, 16, 18, 22, 26, 40, 42, 44, 46, 48, and 60 (fig. 5). The Edwards Group, characterized by shallow- to moderate-depth clayey soils, occurs in all or parts of subwatersheds 20,22, 26, 28, 30, 32, 50, 60, and 62. The Navarro Group and Marlbrook Marl, Pecan Gap Chalk, and Austin Chalk, characterized by deep clayey soils, occur in all or parts of subwatersheds 20 , $22,26,28,30,32,34,50,60,62,64,66,68,70$, and 82 . The Leona Formation and fluviatile terrace deposits, characterized by deep clayey and sandy loam soils, encompass most of subwatersheds $80,84,86,88,90,92,94,96,98,100,102,104$, 106,108 , and 109.

PERLND and IMPLND land-use categories were adapted from the 2004 land-use map shown in figure 2. Land slope was determined from the digital elevation models and input to the model as the average slope for each subwatershed. Average subwatershed slopes range from about 1 percent in the lower, downstream areas of the watershed to about 7 percent in the upstream, headwater areas. Combinations of geology-soils, land use, and land slope in each of the 40 subwatersheds result in 520 possible unique HRU types.
Streamflow losses in the Edwards aquifer recharge zone in the Leon Creek watershed have not been quantified to the level required for HSPF simulation. However, streamflow gain and loss measurements in the recharge zone have been made in nearby Salado Creek (fig. 1) (Ockerman, 2002). The Salado Creek data were used to develop initial estimates of streamflow losses in the Leon Creek watershed. HSPF does not include explicit process parameters or specific features to account for streamflow losses. For the Leon model, these losses were simulated as water withdrawals from the stream reaches. The withdrawals were then routed to groundwater recharge. The withdrawals are established in HSPF hydraulic routing (FTABLEs) as a function of stream discharge or stream volume.

The HSPF software used for this report (version 12) limits a single simulation to no more than 500 model "operations." Each unique PERLND, IMPLND, and RCHRES model element (as well as certain model utility functions) is considered an operation. Because the Leon Creek model comprises more than 500 model elements, the model was actually configured as three separate models, one for upper Leon Creek, one for Culebra Creek, and one for lower Leon Creek (fig. 5). To simulate the entire watershed, the separate models were run sequentially. The outputs from the upper Leon Creek and Culebra Creek models were used as input, or boundary conditions, for the lower Leon Creek model. However, for simplicity, reference in the remainder of the report will continue to be to "the Leon Creek model."

\section{Model Calibration and Testing}

Model calibration is the process by which initial estimates of model process-related parameters are adjusted until simulated streamflows and constituent concentrations and loads acceptably match measured (observed) data. Various acceptance criteria can be used, such as matching of peak streamflows, high streamflows, base flows, and low flows or combinations. The match between measured and simulated values can be assessed by statistics such as means, medians, variances, and by graphical comparisons. For the HSPF model, calibration is an inherently iterative procedure of parameter evaluation and adjustment based on comparison of measured and simulated values.

Model testing involves comparing calibrated-model simulations with measured data that were not used in the calibration. For this report, model testing was done for hydrologic simulations at the most downstream streamflowgaging station (08181480 Leon Creek at IH 35 at San Antonio). Because of few water-quality data, model testing was not done for water-quality simulations.

\section{Streamflow}

A primary goal of model calibration is to adjust simulated streamflow to match streamflow measured at a 


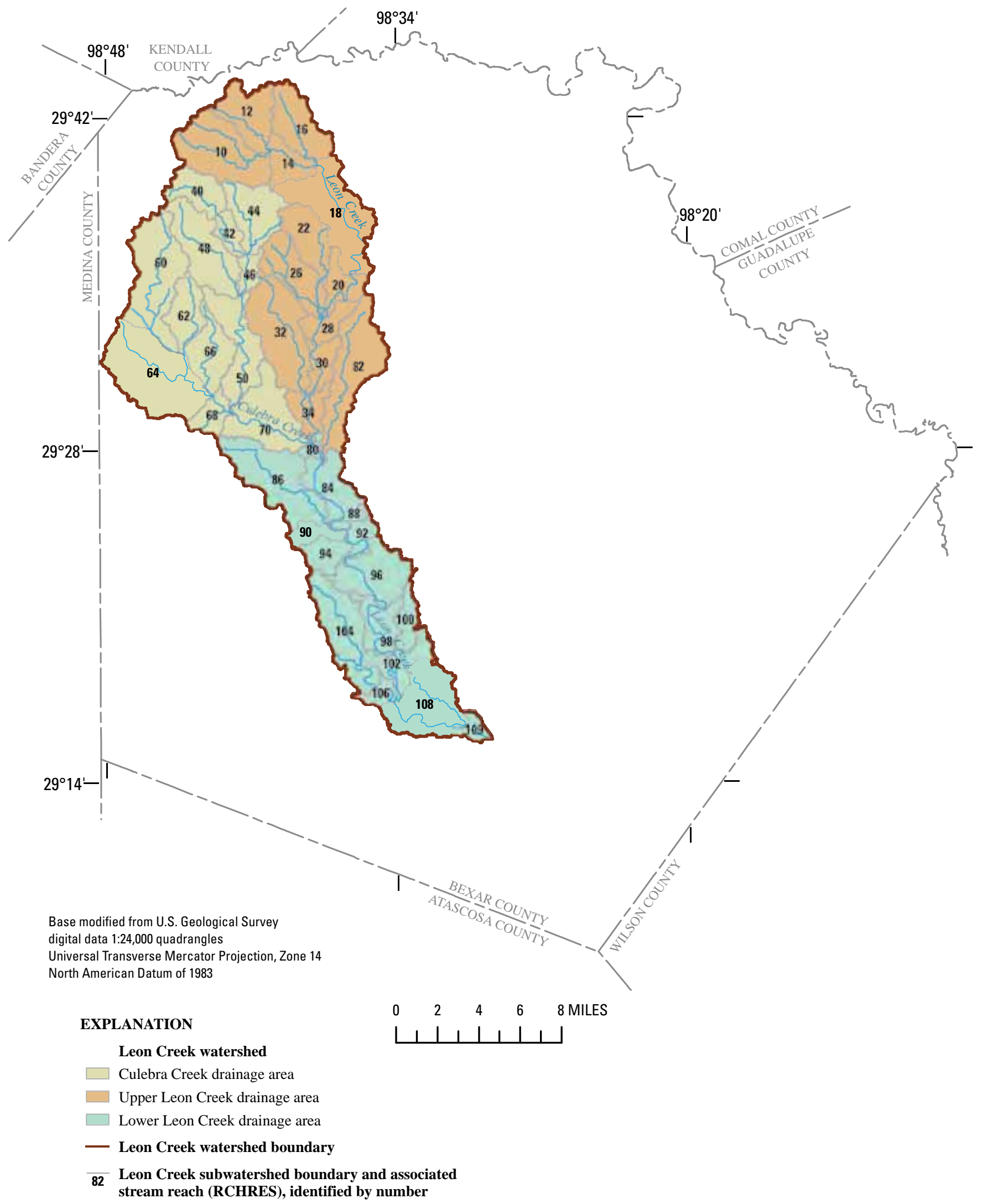

Figure 5. Delineated subwatersheds for the Hydrological Simulation Program—FORTRAN model of the Leon Creek watershed, Bexar County, Texas. 
streamflow-gaging station. The Leon Creek model was calibrated in accordance with the guidelines of Donigian and others (1984) and Lumb and others (1994). The calibration generally entailed adjusting the process-related parameter values to improve the model fit. Criteria such as error in total streamflow volume for the calibration period, low-flow and high-flow distribution, and error in peak flows were used to evaluate how well simulated streamflow represented measured streamflow. For this report, simulation errors were evaluated by comparing total streamflow volume, 50-percent lowest daily flows, 10-percent highest daily flows, and peak flows for selected storms.

Model-fit statistics generated by the software program GenScn (Generation and Analysis of Model Simulation Scenarios) (Aqua Terra Consultants, 2007) were used to examine the quality of the model fit on annual, monthly, daily, and hourly bases for the (1) coefficient of determination $\left(\mathrm{R}^{2}\right)$ of the linear regression between measured and simulated streamflow; (2) Nash-Sutcliff coefficient of model-fit efficiency (NSE), which measures the proportion of variance in the measured streamflow explained by the simulated streamflow (Nash and Sutcliff, 1970); (3) mean absolute error (MAE); and (4) root mean square error (RMSE). $\mathrm{R}^{2}$ and NSE are similar because each provides a measure of the variation in the simulated value explained by the measured value. NSE, however, provides a generally preferable evaluation of the fit quality than does $\mathrm{R}^{2}$ because NSE measures the magnitude of the differences between measured and simulated values, whereas the $\mathrm{R}^{2}$ measures the difference between mean values (Zarriello and Ries, 2000, p. 44). MAE and RMSE express the difference between measured and simulated streamflow in original units (cubic feet per second).

Data were obtained for model calibration, testing, and simulation from five USGS streamflow-gaging stations in the watershed. Station 08181400 Helotes Creek at Helotes, Tex. (site 7) (fig. 4; table 1) monitors streamflow from 15.0 square miles in the upper part of the watershed and has been in operation since 1969. Station 08181480 Leon Creek at IH 35 at San Antonio (site 15), which is on lower Leon Creek, monitors streamflow from 219 square miles and has been in operation since 1984 . Three partial-record gaging stations ${ }^{1}$ also provided stormflow data used in the calibration process. Station 08180945 Leon Creek at Scenic Loop Road near Leon Springs, Tex. (site 5) monitors 10.0 square miles in the upper part of the watershed. Station 08180941 Government Canyon Creek site 2 near Helotes, Tex. (site 4) monitors 12.4 square miles in the upper part of the watershed. Station 08181050 Leon Creek at Prue Road at San Antonio, Tex. (site 6), which is in the central part of the watershed, monitors the upper 58.2 square miles of the Leon Creek watershed. From this network of five stations, selected streamflow data from the period 1997-2004 were used for model streamflow calibration

\footnotetext{
${ }^{1}$ When few streamflow data are collected on a systematic basis over a period of years, the site at which the data are collected is called a partialrecord station.
}

and testing. All streamflow data used are stored by site in the USGS National Water Information System (U.S. Geological Survey, 2009).

The streamflow calibration process was accomplished beginning with the most upstream subwatersheds, using available gaging-station data to adjust model process-related parameters. Data from station 08181400 Helotes Creek at Helotes (site 7) (fig. 4; table 1) were used to calibrate model streamflow for the model subwatersheds upstream from the gage (subwatersheds 40, 42, 44, and 46) (fig. 5). Data from the station 08180945 Leon Creek at Scenic Loop Road (site 5) were used to calibrate model subwatershed 10. Data from station 08180941 Government Canyon Creek near Helotes (site 4) were used to calibrate model subwatershed 60. The process-related parameter values resulting from the calibration using data from upstream gages were then applied to subwatersheds upstream from the next downstream gage, station 08181050 Leon Creek at Prue Road (site 6). Additional streamflow calibration was done using data from station 08181050 to adjust process-related parameters for subwatersheds between stations 08180945 and 08181050 . Next, the calibration of streamflow at station 08181480 Leon Creek at IH 35 (site 15) was refined by further adjusting parameters for subwatersheds downstream from the previously calibrated gaging stations. Finally, the same process-related parameters for subwatershed 98 associated with station 08181480 were applied to ungaged subwatersheds 100, 102, 104, 106, 108, and 109 downstream from this station.

The Leon Creek model output at station 08181480 Leon Creek at IH 35 (site 15) was calibrated using available streamflow data from the period January 1, 2001, to December 31, 2004. The response of the calibrated model was tested using available data from the period January 1, 1997, to December 31, 2000. Because of intermittent streamflow at gaging stations upstream from station 08181480 and because some stations were not in operation during the entire calibration and testing time periods, the post-calibration testing was done only for the model output at station 08181480 .

Streamflow calibration results for stations 08180941 (site 4), 08180945 (site 5), 08181050 (site 6), 08181400 (site 7), and 08181480 (site 15), and testing results for station 08181480 (site 15), are listed in table 2. For each station, simulation errors and other statistics related to the quality of the model calibration are included.

Simulation errors for other criteria generally were within acceptable limits, on the basis of applicable criteria guidelines suggested by Lumb and others (1994). Although runoff volumes for most storms were adequately simulated, simulated peak streamflows, especially those for very large floods (June 1997, October 1998, and July 2002), were less than reported values. Simulated runoff volumes and simulated peak streamflows for the October 1998 flood were substantially lower than reported values. Measured runoff volumes at station 08181480 Leon Creek at IH 35 for October 1998 (a short period of unusually high flood flows) accounted for about 49 percent of the total volume during the 1997-2000 testing period. 
Table 2. Streamflow calibration (five gaging stations) and testing (one gaging station) results for the Hydrological Simulation Program—FORTRAN model of the Leon Creek watershed, Bexar County, Texas.

[acre-ft, acre-feet; $\mathrm{ft}^{3} / \mathrm{s}$, cubic feet per second; --, not applicable]

08180941 Government Canyon Creek site 2 near Helotes, Texas (site 4)

Calibration period 2003-04

\begin{tabular}{|c|c|c|c|c|}
\hline Streamflow volumes and peaks & Measured & Simulated & $\begin{array}{c}\text { Error }^{1} \\
\text { (percent) }\end{array}$ & $\begin{array}{l}\text { Criterion'2 } \\
\text { (percent) } \\
\end{array}$ \\
\hline Total flow volume (acre-ft) & 1,750 & 1,860 & 5.9 & 10 \\
\hline Average daily mean flow rate $\left(\mathrm{ft}^{3} / \mathrm{s}\right)$ & 1.21 & 1.28 & 5.9 & 10 \\
\hline $\begin{array}{l}\text { Total of highest } 10 \text { percent of daily } \\
\text { flows (acre-ft) }\end{array}$ & 1,750 & 1,860 & 5.9 & 10 \\
\hline $\begin{array}{l}\text { Total of lowest } 50 \text { percent of daily } \\
\text { flows (acre-ft) }\end{array}$ & 0 & 0 & 0 & 10 \\
\hline $\begin{array}{l}\text { Average of selected storm peaks } \\
\left(\mathrm{ft}^{3} / \mathrm{s}\right) \text { (two storms) }\end{array}$ & 1,890 & 1,600 & -15.3 & -- \\
\hline Model-fit statistics 2003-04 & Annual & Monthly & Daily & Hourly \\
\hline $\begin{array}{l}\text { Number of years, months, days, or } \\
\text { hours }\end{array}$ & 2 & 24 & 731 & 17,544 \\
\hline Coefficient of determination $\left(\mathrm{R}^{2}\right)$ & 1.00 & 1.00 & .94 & .36 \\
\hline $\begin{array}{l}\text { Nash-Sutcliff coefficient of model- } \\
\text { fit efficiency (NSE) }\end{array}$ & .99 & 1.00 & .94 & .14 \\
\hline Mean absolute error $\left(\mathrm{ft}^{3} / \mathrm{s}\right)$ & .07 & .10 & .43 & .95 \\
\hline Root mean square error $\left(\mathrm{ft}^{3} / \mathrm{s}\right)$ & .10 & .32 & 4.6 & 28 \\
\hline
\end{tabular}

08180945 Leon Creek at Scenic Loop Road near Leon Springs, Texas (site 5)

Calibration period 2001-04

\begin{tabular}{|c|c|c|c|c|}
\hline Streamflow volumes and peaks & Measured & Simulated & $\begin{array}{c}\text { Error }^{1} \\
\text { (percent) }\end{array}$ & $\begin{array}{l}\text { Criterion }^{2} \\
\text { (percent) }\end{array}$ \\
\hline Total flow volume (acre-ft) & 20,000 & 19,200 & -4.0 & 10 \\
\hline Average daily mean flow rate $\left(\mathrm{ft}^{3} / \mathrm{s}\right)$ & 6.92 & 6.64 & -4.0 & 10 \\
\hline $\begin{array}{l}\text { Total of highest } 10 \text { percent of daily } \\
\text { flows (acre-ft) }\end{array}$ & 19,800 & 18,300 & -7.6 & 10 \\
\hline $\begin{array}{l}\text { Total of lowest } 50 \text { percent of daily } \\
\text { flows (acre-ft) }\end{array}$ & 0 & 0 & 0 & 10 \\
\hline $\begin{array}{l}\text { Average of selected storm peaks } \\
\left(\mathrm{ft}^{3} / \mathrm{s}\right) \text { (four storms) }\end{array}$ & 4,520 & 4,080 & -9.7 & -- \\
\hline Model-fit statistics 2001-04 & Annual & Monthly & Daily & Hourly \\
\hline $\begin{array}{l}\text { Number of years, months, days, or } \\
\text { hours }\end{array}$ & 4 & 48 & 1,461 & 35,064 \\
\hline Coefficient of determination $\left(\mathrm{R}^{2}\right)$ & .98 & .97 & .94 & .45 \\
\hline $\begin{array}{l}\text { Nash-Sutcliff coefficient of model- } \\
\text { fit efficiency (NSE) }\end{array}$ & .97 & .97 & .97 & .20 \\
\hline Mean absolute error $\left(\mathrm{ft}^{3} / \mathrm{s}\right)$ & 1.2 & 2.4 & 3.4 & 5.0 \\
\hline Root mean square error $\left(\mathrm{ft}^{3} / \mathrm{s}\right)$ & 1.3 & 5.4 & 17 & 79 \\
\hline
\end{tabular}


Table 2. Streamflow calibration (five gaging stations) and testing (one gaging station) results for the Hydrological Simulation Program-FORTRAN model of the Leon Creek watershed, Bexar County, Texas - Continued.

08181050 Leon Creek at Prue Road at San Antonio, Texas (site 6)

Calibration period 2001-03

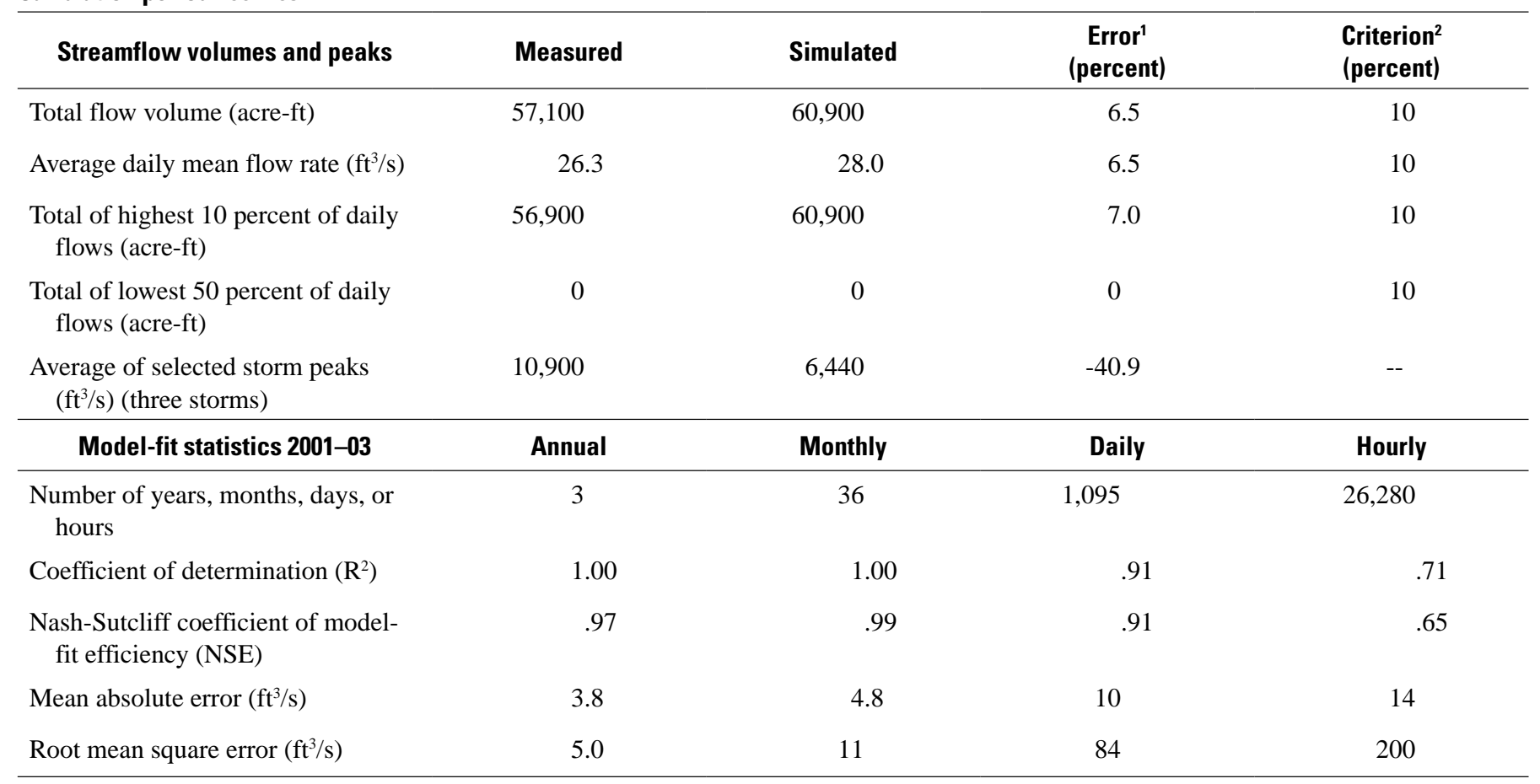

08181400 Helotes Creek at Helotes, Texas (site 7)

Calibration period 2000-2001

\begin{tabular}{|c|c|c|c|c|}
\hline Streamflow volumes and peaks & Measured & Simulated & $\begin{array}{c}\text { Error }^{1} \\
\text { (percent) }\end{array}$ & $\begin{array}{l}\text { Criterion" } \\
\text { (percent) }\end{array}$ \\
\hline Total flow volume (acre-ft) & 6,270 & 5,930 & -5.7 & 10 \\
\hline $\begin{array}{l}\text { Total of highest } 10 \text { percent of daily } \\
\text { flows (acre-ft) }\end{array}$ & 4,740 & 5,050 & 6.5 & 10 \\
\hline $\begin{array}{l}\text { Average of selected storm peaks } \\
\left(\mathrm{ft}^{3} / \mathrm{s}\right) \text { (three storms) }\end{array}$ & 673 & 1,000 & 48.6 & -- \\
\hline Model-fit statistics 2000-2001 & Annual & Monthly & Daily & Hourly \\
\hline $\begin{array}{l}\text { Number of years, months, days, or } \\
\text { hours }\end{array}$ & 2 & 24 & 731 & 17,544 \\
\hline Mean absolute error $\left(\mathrm{ft}^{3} / \mathrm{s}\right)$ & .81 & 3.4 & 3.6 & 3.9 \\
\hline Root mean square error $\left(\mathrm{ft}^{3} / \mathrm{s}\right)$ & .85 & 5.6 & 10 & 25 \\
\hline
\end{tabular}


Table 2. Streamflow calibration (five gaging stations) and testing (one gaging station) results for the Hydrological Simulation Program—FORTRAN model of the Leon Creek watershed, Bexar County, Texas-Continued.

08181480 Leon Creek at Interstate Highway 35 at San Antonio, Texas (site 15)

Calibration period 2001-04

\begin{tabular}{|c|c|c|c|c|}
\hline Streamflow volumes and peaks & Measured & Simulated & $\begin{array}{c}\text { Error }^{1} \\
\text { (percent) }\end{array}$ & $\begin{array}{l}\text { Criterion } \\
\text { (percent) }\end{array}$ \\
\hline Total flow volume (acre-ft) & 343,000 & 366,000 & 6.8 & 10 \\
\hline Average daily mean flow rate $\left(\mathrm{ft}^{3} / \mathrm{s}\right)$ & 118 & 126 & 6.8 & 10 \\
\hline $\begin{array}{l}\text { Total of highest } 10 \text { percent of daily } \\
\text { flows (acre-ft) }\end{array}$ & 159,000 & 168,000 & 5.7 & 10 \\
\hline $\begin{array}{l}\text { Total of lowest } 50 \text { percent of daily } \\
\text { flows (acre-ft) }\end{array}$ & 3,890 & 4,070 & 4.6 & 10 \\
\hline $\begin{array}{l}\text { Average of selected storm peaks } \\
\left(\mathrm{ft}^{3} / \mathrm{s}\right) \text { (five storms) }\end{array}$ & 21,100 & 16,200 & -23.2 & -- \\
\hline Model-fit statistics 2001-04 & Annual & Monthly & Daily & Hourly \\
\hline $\begin{array}{l}\text { Number of years, months, days, or } \\
\text { hours }\end{array}$ & 4 & 48 & 1,461 & 35,064 \\
\hline Coefficient of determination $\left(\mathrm{R}^{2}\right)$ & .99 & .99 & .97 & .81 \\
\hline $\begin{array}{l}\text { Nash-Sutcliff coefficient of model- } \\
\text { fit efficiency (NSE) }\end{array}$ & .98 & .99 & .97 & .79 \\
\hline Mean absolute error $\left(\mathrm{ft}^{3} / \mathrm{s}\right)$ & 15.5 & 21.6 & 38.0 & 64.6 \\
\hline Root mean square error $\left(\mathrm{ft}^{3} / \mathrm{s}\right)$ & 19.1 & 51.8 & 187 & 512 \\
\hline
\end{tabular}

08181480 Leon Creek at Interstate Highway 35 at San Antonio, Texas (site 15) Testing period 1997-2000

\begin{tabular}{|c|c|c|c|c|}
\hline Streamflow volumes and peaks & Measured & Simulated & $\begin{array}{c}\text { Error }^{1} \\
\text { (percent) }\end{array}$ & $\begin{array}{l}\text { Criterion2 }^{2} \\
\text { (percent) }\end{array}$ \\
\hline Total flow volume (acre-ft) & 226,000 & 212,000 & -6.0 & 10 \\
\hline Average daily mean flow rate $\left(\mathrm{ft}^{3} / \mathrm{s}\right)$ & 78 & 73 & -6.0 & 10 \\
\hline $\begin{array}{l}\text { Total of highest } 10 \text { percent of daily } \\
\text { flows (acre-ft) }\end{array}$ & 62,500 & 62,400 & -.2 & 10 \\
\hline $\begin{array}{l}\text { Total of lowest } 50 \text { percent of daily } \\
\text { flows (acre-ft) }\end{array}$ & 3,680 & 3,440 & -6.5 & 10 \\
\hline $\begin{array}{l}\text { Average of selected storm peaks } \\
\left(\mathrm{ft}^{3} / \mathrm{s}\right) \text { (three storms) }\end{array}$ & 14,100 & 11,600 & -17.7 & -- \\
\hline Model-fit statistics $1997-2000^{3}$ & Annual & Monthly & Daily & Hourly \\
\hline $\begin{array}{l}\text { Number of years, months, days, or } \\
\text { hours }\end{array}$ & 4 & 47 & 1,430 & 34,320 \\
\hline Coefficient of determination $\left(\mathrm{R}^{2}\right)$ & .94 & .87 & .77 & .33 \\
\hline $\begin{array}{l}\text { Nash-Sutcliff coefficient of model- } \\
\text { fit efficiency (NSE) }\end{array}$ & .83 & .82 & .76 & .01 \\
\hline Mean absolute error $\left(\mathrm{ft}^{3} / \mathrm{s}\right)$ & 18.8 & 23.5 & 33.6 & 114 \\
\hline Root mean square error $\left(\mathrm{ft}^{3} / \mathrm{s}\right)$ & 19.5 & 38.0 & 160 & 407 \\
\hline
\end{tabular}


Table 2. Streamflow calibration (five gaging stations) and testing (one gaging station) results for the Hydrological Simulation Program—FORTRAN model of the Leon Creek watershed, Bexar County, Texas-Continued.

Leon Creek at Interstate Highway 35 at San Antonio, Texas - 08181480 (site 15) Simulation period 1997-2004

\begin{tabular}{|c|c|c|c|c|}
\hline Streamflow volumes and peaks & Measured & Simulated & $\begin{array}{c}\text { Error }^{1} \\
\text { (percent) }\end{array}$ & $\begin{array}{l}\text { Criterion' } \\
\text { (percent) }\end{array}$ \\
\hline Total flow volume (acre-ft) & 569,000 & 579,000 & 1.8 & 10 \\
\hline Average daily mean flow rate $\left(\mathrm{ft}^{3} / \mathrm{s}\right)$ & 98 & 100 & 1.8 & 10 \\
\hline $\begin{array}{l}\text { Total of highest } 10 \text { percent of daily } \\
\text { flows (acre-ft) }\end{array}$ & 264,000 & 261,000 & -1.1 & 10 \\
\hline $\begin{array}{l}\text { Total of lowest } 50 \text { percent of daily } \\
\text { flows (acre-ft) }\end{array}$ & 6,040 & 6,640 & 9.9 & 10 \\
\hline $\begin{array}{l}\text { Average of selected storm peaks } \\
\left(\mathrm{ft}^{3} / \mathrm{s}\right)(8 \text { storms })\end{array}$ & 18,500 & 14,500 & -21.6 & -- \\
\hline Model-fit statistics 1997-2004 & Annual & Monthly & Daily & Hourly \\
\hline $\begin{array}{l}\text { Number of years, months, days, or } \\
\text { hours }\end{array}$ & 7.9 & 95 & 2,891 & 69,384 \\
\hline Coefficient of determination $\left(\mathrm{R}^{2}\right)$ & .99 & .99 & .95 & .74 \\
\hline $\begin{array}{l}\text { Nash-Sutcliff coefficient of model- } \\
\text { fit efficiency (NSE) }\end{array}$ & .97 & .98 & .95 & .70 \\
\hline Mean absolute error $\left(\mathrm{ft}^{3} / \mathrm{s}\right)$ & 15.7 & 22.5 & 35.8 & 54.9 \\
\hline Root mean square error $\left(\mathrm{ft}^{3} / \mathrm{s}\right)$ & 18.5 & 45.5 & 174 & 463 \\
\hline
\end{tabular}

${ }^{1}$ Error $=[($ simulated - measured $) /$ measured $] \times 100$.

${ }^{2}$ Default error criteria from HSPEXP (Lumb and others, 1994).

${ }^{3}$ Excludes October 1998.

Consequently, simulation errors during the 1997-2000 testing period are substantially influenced by the October 1998 flood. For this reason, model-fit statistics listed in table 2 excluded October 1998 data. Possible reasons for poor simulation of the October 1998 streamflow include general uncertainty in rainfall and peak streamflow values. NEXRAD rainfall data used as input for the Leon Creek model might have been underestimated for the October 1998 flood. October 1998 NEXRAD rainfall totals used for model simulation ranged from about 11.4 to 14.8 inches. In contrast, rainfall measured at the San Antonio International airport (site 2) (fig. 4; table 1) during October 1998 was 18.1 inches. Also, the reported peak streamflow at station 08181480 for October 1998 was not directly measured but was estimated by indirect methods (Gandara and others, 2000, p. 184).

Simulated flows at the five USGS stations also were evaluated graphically by comparing measured and simulated daily time series and exceedance-probability (flow-duration) curves. General agreement between the measured and simulated exceedance-probability curves indicate adequate calibration over the range of flow conditions. Figures $6-8$ show daily time series, exceedance probability curves, and scatter plots of measured daily and simulated daily streamflow at stations 08180945 Leon Creek at Scenic Loop Road, 08181050 Leon Creek at Prue Road, and 08181480 Leon Creek at IH 35, respectively. The authors judge that plots for all three sites show reasonable agreement for the range of flow conditions. Also, comparison of the exceedance-probability plots between the three gaging stations show the differences in actual (measured) streamflow duration between the upstream and downstream parts of the Leon Creek watershed.

Donigian and others (1984) presents general, qualitative guidelines for characterizing HSPF calibrations. For annual and monthly streamflow volumes, model calibration is considered very good when the error is less than 10 percent, good when error is $10-15$ percent, and fair when error is $15-25$ percent. By these guidelines, calibration results for annual streamflow volumes at all stations are very good. Annual, monthly, and daily $\mathrm{R}^{2}$ and NSE values are considered acceptable for all stations. The NSE for daily streamflow volumes ranged from .80 to .97 for the calibration periods at all stations (table 2). The NSE for daily streamflow volumes 

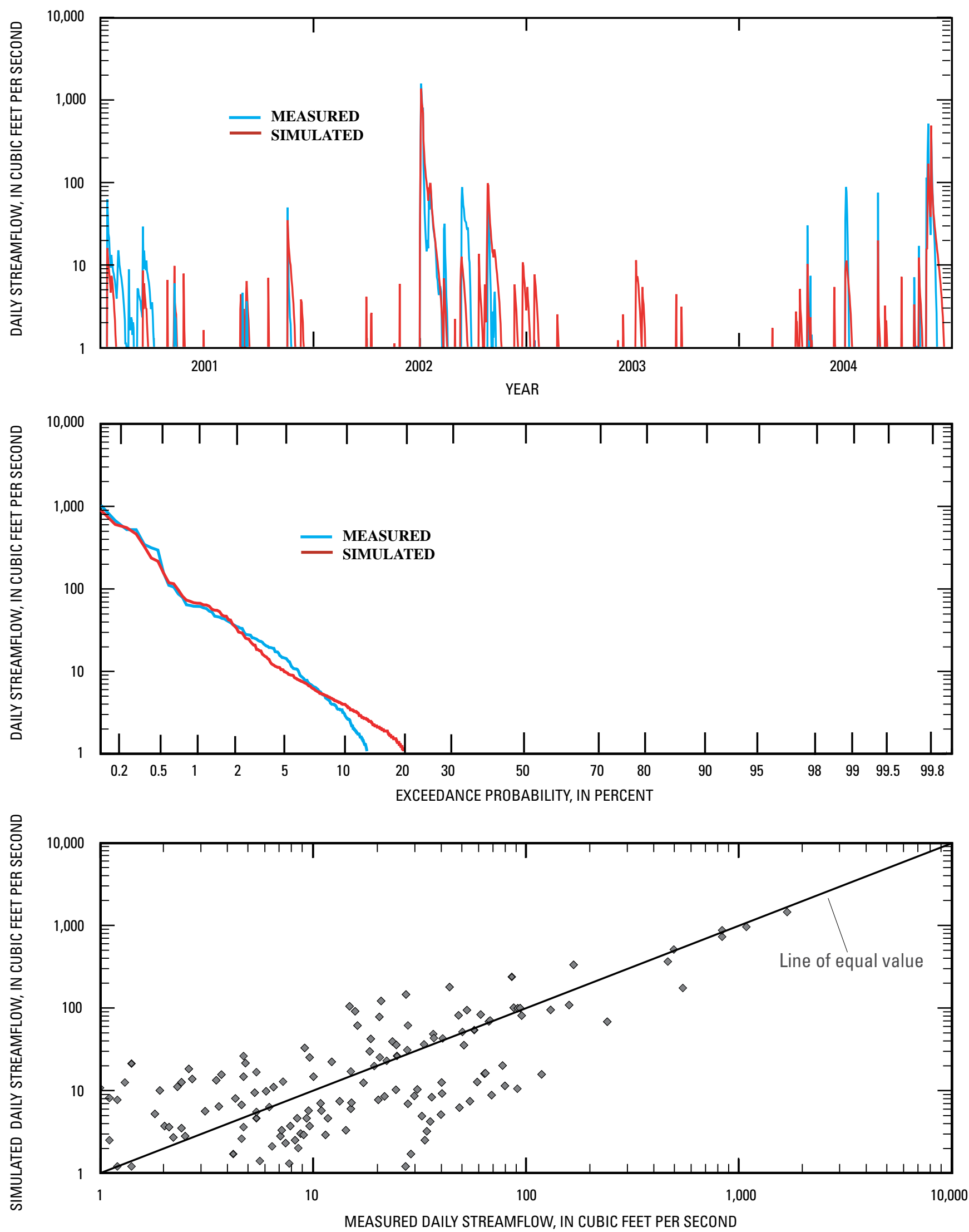

Figure 6. Measured and simulated daily mean streamflow at station 08180945 Leon Creek at Scenic Loop Road near Leon Springs, Texas, 2001-04. 

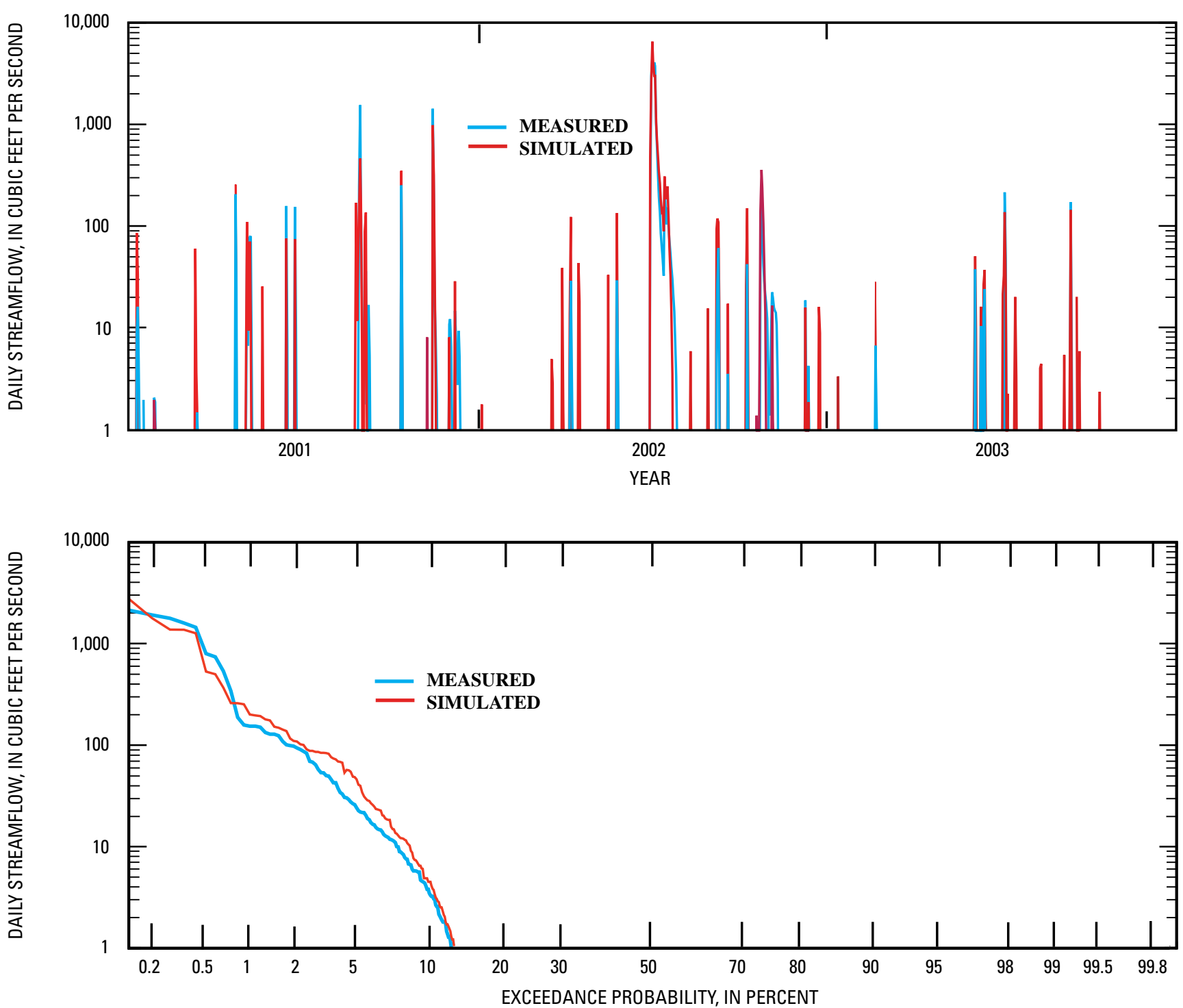

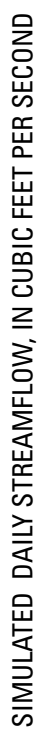

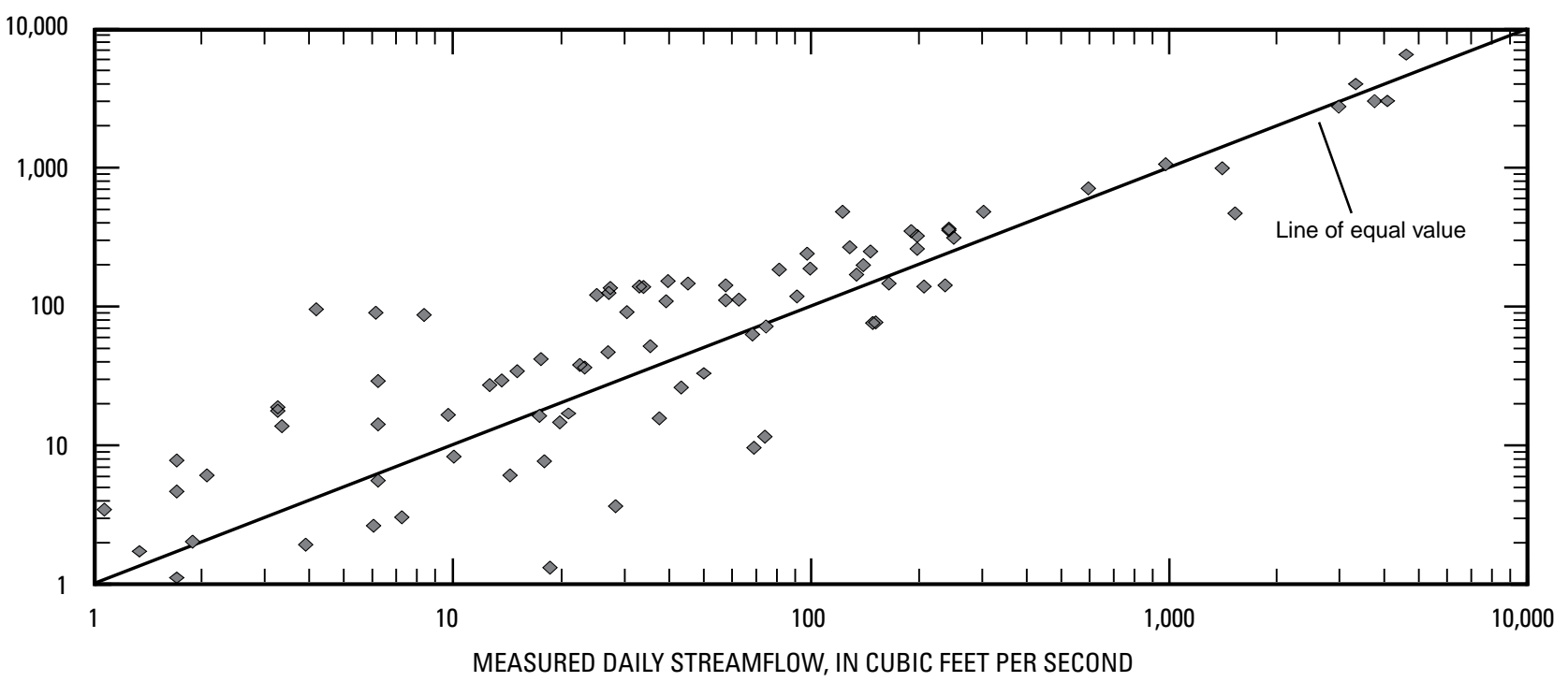

Figure 7. Measured and simulated daily mean streamflow at station 08181050 Leon Creek at Prue Road at San Antonio, Texas, 2001-03. 

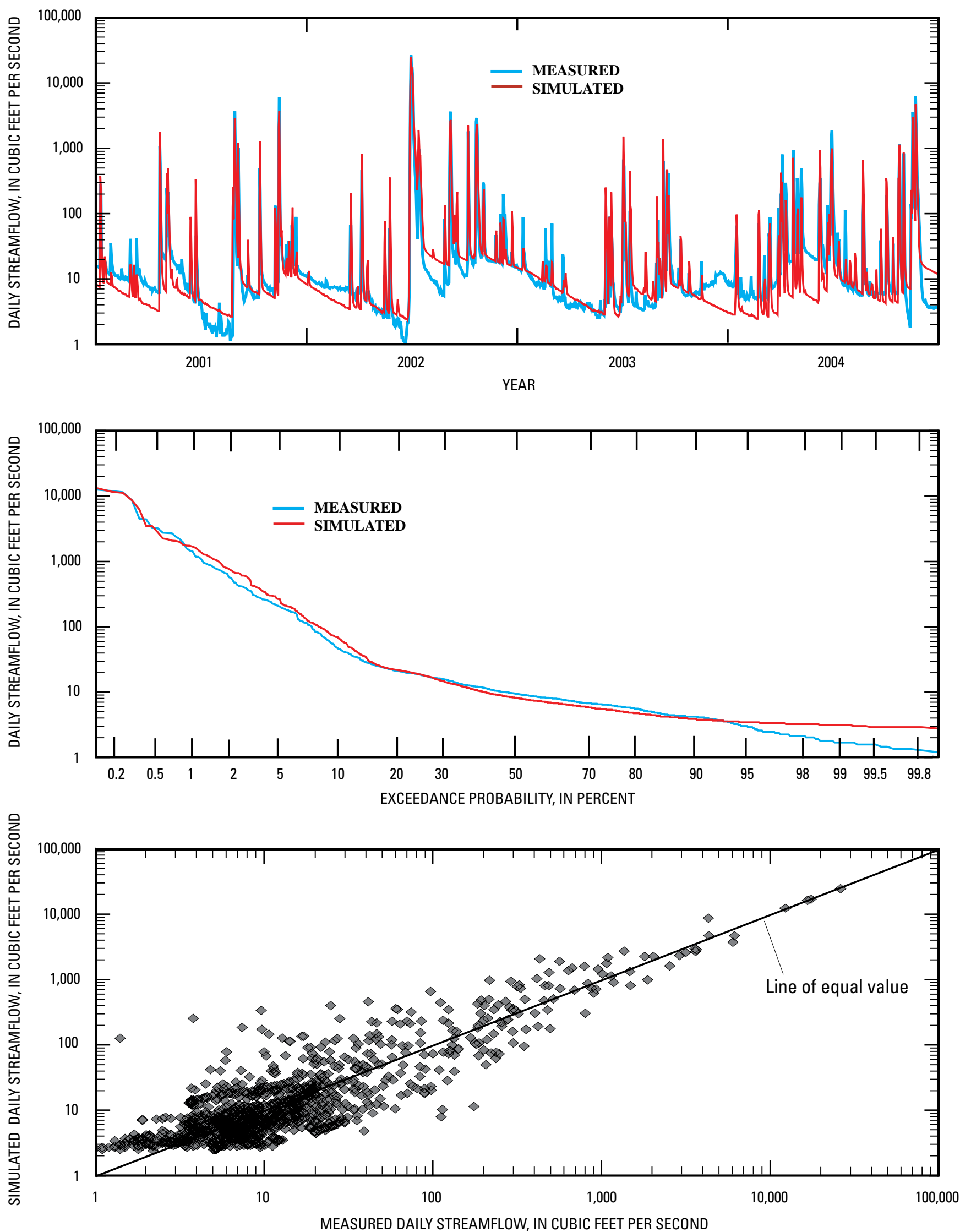

Figure 8. Measured and simulated daily mean streamflow at station 08181480 Leon Creek at Interstate Highway 35 at San Antonio, Texas, 2001-04. 
Table 3. Summary of calibrated values for selected hydrology-related parameters for the Hydrological Simulation Program—FORTRAN model of the Leon Creek watershed, Bexar County, Texas.

[PERLND, pervious land surface; IMPLND, impervious land surface]

\begin{tabular}{lllc}
\hline Parameter & \multicolumn{1}{c}{$\begin{array}{c}\text { Hydrologic response } \\
\text { unit category }\end{array}$} & \multicolumn{1}{c}{ Description } & Value \\
\hline AGWETP & PERLND & Fraction of remaining evapotranspiration from active groundwater & 0 \\
AGWRC & PERLND & Basic groundwater recession rate & $.90-.985$ \\
BASETP & PERLND & Fraction of available evapotranspiration to be met from base flow & 0 \\
CEPSC & PERLND & Interception storage capacity & $.10-.40$ \\
DEEPFR & PERLND & Fraction of groundwater inflow to deep recharge & $.15-.80$ \\
INFEXP & PERLND & Infiltration equation exponent & 2 \\
INFILD & PERLND & Ratio of maximum and mean infiltration rates & 2 \\
INFILT & PERLND & Index to infiltration capacity of soil & $.16-.25$ \\
INTFW & PERLND & Index to amount of water that infiltrates and flows as interflow & $1.0-1.5$ \\
IRC & PERLND & Interflow recession coefficient & $.50-.60$ \\
KVARY & PERLND & Groundwater outflow modifier & 0 \\
LSUR & PERLND or IMPLND & Average length of overland-flow plane & $250-300$ \\
LZETP & PERLND & Lower-zone evapotranspiration & $0-.70$ \\
LZSN & PERLND & Lower-zone nominal storage & $3.1-6.0$ \\
NSUR & PERLND or IMPLND & Average roughness coefficient for overland-flow plane & $.1-.35$ \\
RETSC & IMPLND & Impervious retention storage capacity & .25 \\
SLSUR & PERLND or IMPLND & Average slope of overland-flow plane & $.021-.072$ \\
UZSN & PERLND & Upper-zone nominal storage & $.42-.80$ \\
\hline
\end{tabular}

for the testing period at the Leon Creek at IH 35 station was .76 as opposed to .97 for the calibration period. Generally, $\mathrm{R}^{2}$ and NSE were lower for hourly simulations, especially the 1997-2000 testing period at Leon Creek at IH 35. The NSE for hourly simulations ranged from .14 to .79 for the calibration periods at all stations. The NSE for hourly simulations for the testing period at Leon Creek at IH 35 station was .01 and is considered poor compared with .79 for the calibration period. The NSE for hourly values for the entire 1997-2004 simulation period at the Leon Creek at IH 35 station was .70, which is considered good.

Although streamflow is perennial at station 08181480 Leon Creek at IH 35, streamflows in the upstream areas of the watershed (stations 08180941, 08180945, 08181050, and 08181400) are intermittent. Model simulations at the outlets of upper Leon Creek (RCHRES 34) (fig. 5) and Culebra Creek (RCHRES 70) indicate that during 1997-2004, streamflow at these sites occurred about 20 percent of the time. The drainage area of the Leon Creek watershed upstream from these sites accounts for about two-thirds of the watershed drainage area.

Streamflow volumes are greatly influenced by large storms. Two months that included major floods (October
1998 and July 2002) accounted for about 50 percent of all the streamflow measured at station 08181480 Leon Creek at IH 35 (site 15) (fig. 4) during 1997-2004.

Wastewater discharged from the large municipal treatment facility near the mouth of Leon Creek accounted for a substantial part of the total streamflow exiting the Leon Creek watershed during 1997-2004. The average recycled wastewater discharge was about 39,000 acre-feet per year (M. Veazy, Texas Commission on Environmental Quality, written commun., 2001) compared with the average simulated total streamflow of about 127,000 acre-feet per year at the outlet of Leon Creek, or about 31 percent of the average simulated total streamflow. The median simulated streamflow at the mouth of Leon Creek was 66 cubic feet per second compared with 8.3 cubic feet per second at Leon Creek at IH 35 for 1997-2004. Most of this difference was because of the wastewater inflow near the mouth of Leon Creek.

As a result of the streamflow calibration and testing process, a set of hydrology-related parameters were developed for the Leon Creek model. A summary of PERLND and IMPLND hydrology parameter values for the Leon Creek model are listed in table 3 . 


\section{Water Quality}

The HSPF model was calibrated for selected water-quality properties and constituents using data obtained at the sites listed in table 1 and shown in figure 4 . The model was used to simulate water temperature, dissolved oxygen, suspended sediment, dissolved ammonia nitrogen, dissolved nitrate nitrogen, and dissolved and total lead and zinc.

PERLNDs and IMPLNDs are based on land use/cover. Therefore, water-quality data were needed to characterize runoff quality from several land-use types. Water-quality sites 4-7 (fig. 4; table 1) are at outlets of relatively large subbasins in the upstream areas of the Leon Creek watershed. Data from these sites characterize runoff quality from rural and undeveloped land. Also, data from these sites were used to calibrate water-quality parameters for specific subwatersheds upstream from each site. Water-quality sites 8-14 are data-collection sites for seven relatively small, urban land-use watersheds sampled for a previous study during 1992-2005 to characterize runoff quality (B.L. Petri, U.S. Geological Survey, written commun., 2006). Each of the seven watersheds reflects a dominant land use-residential, industrial, commercial, or transportation corridor. Site 15 monitored most of the entire drainage area of the Leon Creek watershed (219 of the 238 square miles), so water-quality data from this site integrate overall water quality from the entire watershed. Data from this site are the most important source of water-quality data for model calibration. Site 16 monitored water quality of discharge from the large wastewater treatment facility near the mouth of the watershed. These data characterize water quality for a substantial source of inflow and associated constituent loads in the watershed. All water-quality data used are stored by site in the USGS National Water Information System (U.S. Geological Survey, 2009).

\section{Water Temperature}

Water-temperature simulations are accomplished in HSPF by the HTRCH section of the RCHRES module. Changes in RCHRES water temperature are simulated by three major processes: (1) heat transfer through movement of water into and out of each RCHRES; (2) heat transfer across the air-water interface; and (3) heat transfer across the water-streambed boundary.

Continuous (15-minute interval) water-temperature data are available for RCHRES 98 (site 15, Leon Creek at IH 35) (figs. 4, 5) for the period 1997-2000. Comparison of these data with simulated water temperature for this site was done to calibrate process-related parameters related to water temperature. Compared to available data for streamflow calibration, data available for water-temperature calibration were few. Therefore, all available data for 1997-2000 were used for the calibration; a post-calibration evaluation of model performance during a separate testing period was not done. Graphs of measured and simulated daily mean water temperatures are shown in figure 9. Measured and simulated mean water tem- perature and model-fit statistics for monthly, daily, and hourly simulations are listed in table 4 . The average daily mean measured water temperature during 1997-2000 was $71.7^{\circ} \mathrm{F}$. The average simulated daily mean temperature during 1997-2000 was $71.6^{\circ} \mathrm{F}$. $\mathrm{R}^{2}$ values for simulated water temperature were .89 for daily values and .84 for hourly values. NSE values for simulated water temperature were .89 for daily values and .83 for hourly values.

RCHRES 98 (site 15, Leon Creek at IH 35) (figs. 4, 5) is the only reach with continuous water-temperature data available for model calibration. The calibrated values of parameters related to RCHRES water temperature at RCHRES 98 were applied to all other model RCHRES. One factor that accounts for differences in water temperature among RCHRESs is elevation. HSPF simulations include a lapse-rate calculation to simulate differences in air temperature because of elevation differences (Bicknell and others, 2001, p. 39). Air temperature, in turn, affects RCHRES water temperature. For example, during July 2002 the simulated average water temperature in RCHRES 98 (elevation about 595 feet above sea level) was $84.3^{\circ} \mathrm{F}$. During the same period, the simulated average water temperature in RCHRES 10 (elevation about 1,260 feet above sea level) was $83.3^{\circ} \mathrm{F}$. If a RCHRES is dry, the water temperature is the same as the simulated air temperature.

\section{Dissolved Oxygen}

Dissolved oxygen simulations are accomplished in HSPF by the OXRX and NUTRX subroutines within the RQUAL RCHRES module. OXRX processes considered in the dissolved oxygen simulations include benthal oxygen release, reaeration, and oxygen depletion from decay of biochemical oxygen demand. NUTRX processes considered in the dissolved oxygen simulations include nitrification of ammonia and nitrite and denitrification of nitrate.

Continuous (15-minute interval) dissolved oxygen data are available for RCHRES 98 (site 15, Leon Creek at IH 35) (figs. 4, 5) for the period 1997-2000. These data, as well as simulated dissolved oxygen data for this site, were used to calibrate process-related parameters related to dissolved oxygen. Graphs of measured and simulated daily mean dissolved oxygen are shown in figure 10. Measured and simulated average dissolved oxygen concentrations and model-fit statistics are listed in table 5 . The average daily mean measured dissolved oxygen during this period was 6.64 milligrams per liter $(\mathrm{mg} / \mathrm{L})$. The average simulated daily mean dissolved oxygen was $6.57 \mathrm{mg} / \mathrm{L}$. Average simulated dissolved oxygen compares satisfactorily with the average measured value. However, the daily and hourly $\mathrm{R}^{2}$ values and NSE values were relatively low. $\mathrm{R}^{2}$ values of simulated dissolved oxygen were .39 and .30 for daily and hourly values, respectively. NSE values of simulated dissolved oxygen were .35 and .18 for daily and hourly values, respectively. Similar to calibration and simulation of water temperature, calibrated values for dissolved oxygen model parameters for RCHRES 98 were applied to all other RCHRESs. 

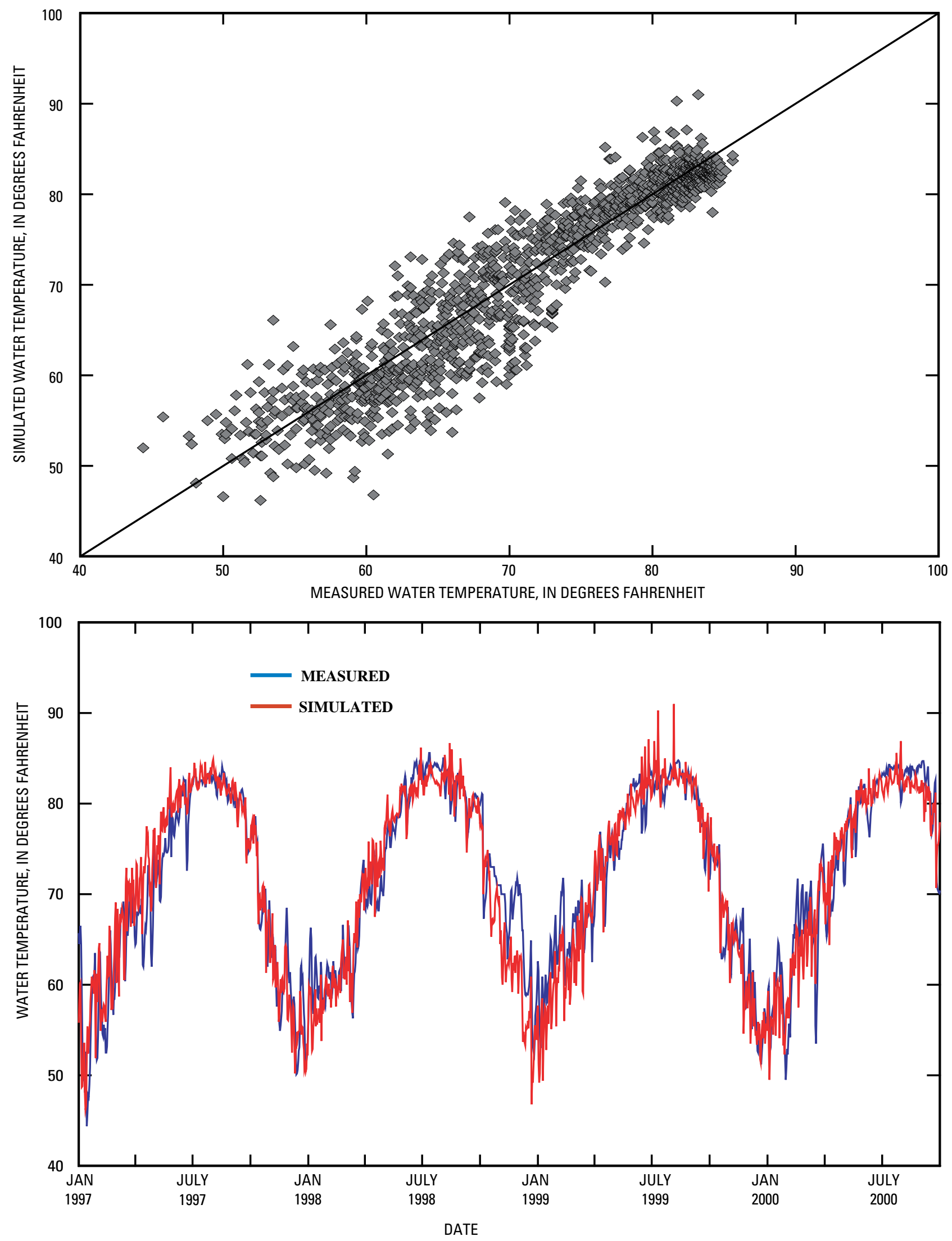

Figure 9. Measured and simulated daily mean water temperature at station 08181480 Leon Creek at Interstate Highway 35 at San Antonio, Texas, 1997-2000. 

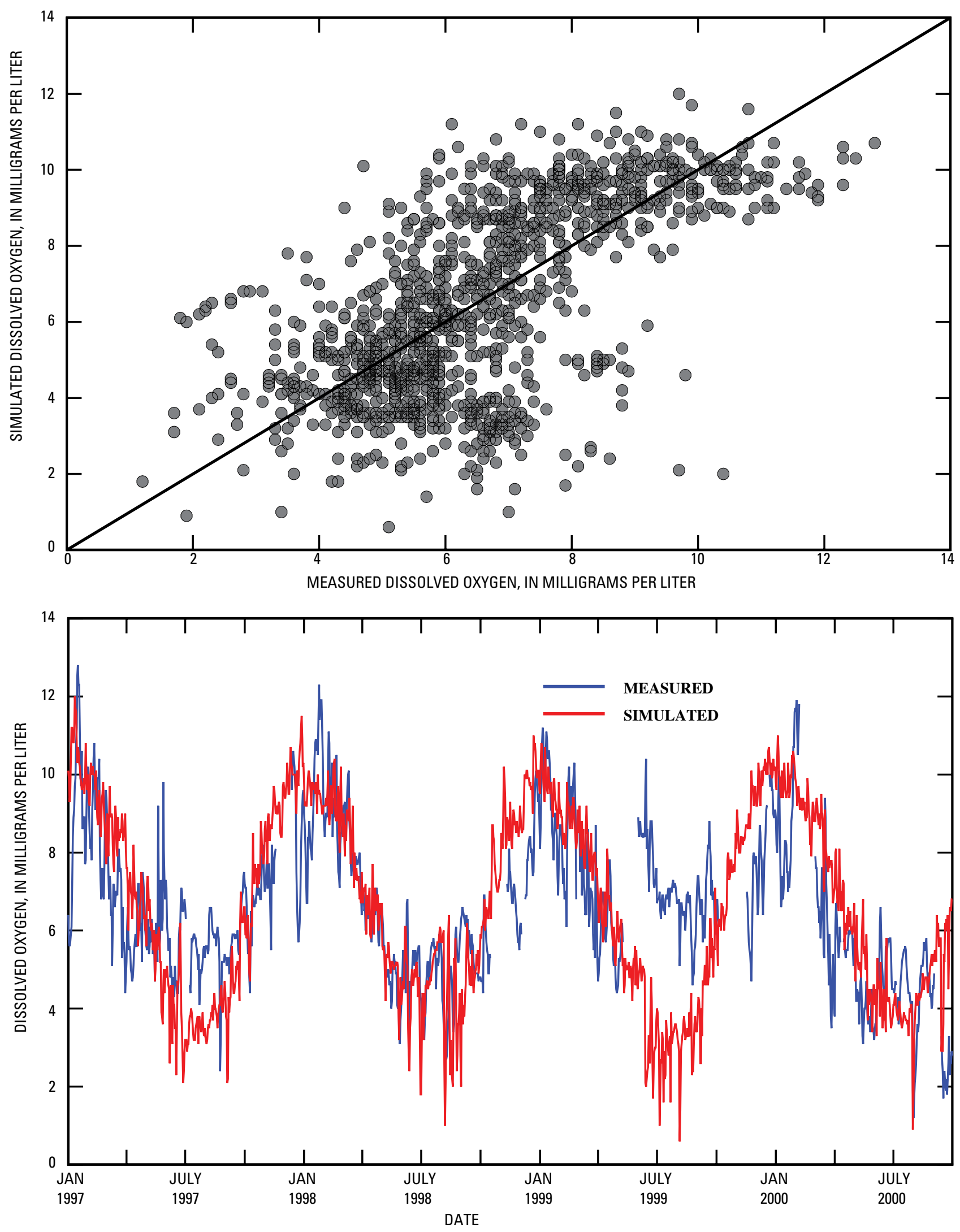

Figure 10. Measured and simulated daily mean dissolved oxygen at station 08181480 Leon Creek at Interstate Highway 35 at San Antonio, Texas, 1997-2000. 
24 Simulation of Streamflow and Water Quality in the Leon Creek Watershed, Bexar County, Texas, 1997-2004

Table 4. Water temperature calibration results for the Hydrological Simulation Program—FORTRAN model of the Leon Creek watershed, Bexar County, Texas.

$\left[{ }^{\circ} \mathrm{F}\right.$, degrees Fahrenheit $]$

08181480 Leon Creek at Interstate Highway 35, San Antonio, Texas (site 15)

Calibration period January 1997-September 2000

\begin{tabular}{|c|c|c|c|}
\hline Measured and simulated values & Measured & Simulated & $\begin{array}{c}\text { Error }^{1} \\
\text { (percent) }\end{array}$ \\
\hline Average daily mean water temperature $\left({ }^{\circ} \mathrm{F}\right)$ & 71.7 & 71.6 & -0.14 \\
\hline Number of months, days, or hours & 45 & 1,368 & 32,856 \\
\hline Coefficient of determination $\left(\mathrm{R}^{2}\right)$ & .97 & .89 & .84 \\
\hline $\begin{array}{l}\text { Nash-Sutcliff coefficient of model-fit } \\
\text { efficiency (NSE) }\end{array}$ & .97 & .89 & .83 \\
\hline Root mean square error $\left({ }^{\circ} \mathrm{F}\right)$ & 1.7 & 3.2 & 4.0 \\
\hline
\end{tabular}

${ }^{1}$ Error $=[($ simulated - measured $) /$ measured $] \times 100$.

Table 5. Dissolved oxygen calibration results for the Hydrological Simulation Program—FORTRAN model of the Leon Creek watershed, Bexar County, Texas.

[mg/L, milligrams per liter]

08181480 Leon Creek at Interstate Highway 35, San Antonio, Texas (site 15)

Calibration period January 1997-September 2000

\begin{tabular}{|c|c|c|c|}
\hline Measured and simulated values & Measured & Simulated & $\begin{array}{c}\text { Error }^{1} \\
\text { (percent) }\end{array}$ \\
\hline Average daily mean dissolved oxygen (mg/L) & 6.64 & 6.57 & -0.11 \\
\hline Number of months, days, or hours & 45 & 1,368 & 32,856 \\
\hline Coefficient of determination $\left(\mathrm{R}^{2}\right)$ & .51 & .39 & .30 \\
\hline $\begin{array}{l}\text { Nash-Sutcliff coefficient of model-fit } \\
\text { efficiency (NSE) }\end{array}$ & .50 & .35 & .18 \\
\hline Root mean square error (mg/L) & 1.6 & 1.9 & 2.2 \\
\hline
\end{tabular}

${ }^{1}$ Error $=[($ simulated - measured $) /$ measured $] \times 100$. 


\section{Suspended Sediment}

Suspended sediment was simulated using the HSPF secondary modules SEDMNT for PERLND simulation, SOLIDS for IMPLND simulation, and SEDTRN for RCHRES simulation. For each PERLND, the processes of detachment of sediment from the soil matrix and washoff of this sediment are simulated in SEDMNT on the basis of rainfall intensity, surface runoff, and the model parameters that control the accumulation, detachment, and transport of soils. For each IMPLND, the processes of accumulation and washoff of sediment are simulated in the SOLIDS module. In each RCHRES, the sediment-transport processes in the stream channel are accomplished by the SEDTRN module. Transport processes in RCHRES include deposition and scour and are functions of the sediment size, settling velocity, density, erodibility, bed depth, and critical shear stress. RCHRES sediment transport is computed separately for each fraction of sediment size-sand, silt, and clay.

Selection of initial values and calibration of sedimentrelated process parameters of the SEDMNT, SOLIDS, and SEDTRN modules (appendix 1) were based on guidelines of Donigian and Love (2003) and U.S. Environmental Protection Agency (2006). Calibration of sediment-related process parameters involved three steps: (1) Estimating soil-erosion parameters that affect generation of sediment flux from PERLNDs and sediment-washoff parameters that affect generation of sediment flux from IMPLNDs; (2) calibrating sediment-transport (RCHRES) parameters by comparison of simulation results with available monitoring data from upstream stations; and (3) further adjusting selected sedimentrelated process parameters on the basis of comparison of measured and simulated data at the most downstream streamflowgaging station.

To develop estimates of soil-erosion and sedimentwashoff parameters for the various PERLNDs and IMPLNDs, respectively, simulated suspended-sediment runoff concentrations from representative PERLNDs and IMPLNDs were compared with measured concentrations from the seven relatively small, urban land-use watersheds (sites 8-14) (fig. 4; table 1) sampled for a previous study, as noted at the beginning of the "Water Quality" section. First, median suspendedsediment runoff concentrations were computed for each of four land-use types (residential, industrial, commercial, transportation corridor) represented in the measured data from sites 8-14. Then, iteratively, PERLND and IMPLND sedimentrelated parameters were adjusted until simulated concentrations of suspended sediment in PERLND and IMPLND runoff matched the target runoff concentrations from the measured data. Table 6 shows simulated suspended-sediment concentrations for four PERLND and IMPLND land-use types compared with median concentrations from the measured data.

After calibrating estimates for PERLND and IMPLND parameters related to soil erosion and sediment washoff, the parameters related to sediment transport were calibrated by comparing simulated suspended-sediment concentrations and loads to computed concentrations and loads from measured data collected at USGS gaging stations 08180941 Government Canyon Creek near Helotes (site 4) (fig. 4; table 1), 08180945 Leon Creek at Scenic Loop Road (site 5), 08181050 Leon Creek at Prue Road (site 6), and 08181400 Helotes Creek at Helotes (site 7) (hereinafter, referred to as the upper-watershed sites). Because of intermittent flow at the upper-watershed sites and relative scarcity of suspended-sediment data, calibrations were based on selected stormflows. Stormflows were selected for calibration of sediment transport on the basis of adequate agreement (a judgment call) between measured and simulated streamflow. Unreliable suspended-sediment calibration could result if the measured and simulated streamflow hydrographs were not reasonably congruent. As a result, only three stormflows were considered for sediment calibration at the upper-watershed sites (none were available for site 7). Generally, for each upper-watershed site, each PERLND and IMPLND land-use type in all subwatersheds upstream from a particular site were assigned the same parameter values. For example, all PERLNDS upstream from site 5 that represent residential land use were assigned the same sedimenttransport parameter values. Because no suspended-sediment data for site 7 were available for calibration, parameters for adjacent upper-watershed sites (site 4 or 5) were used. Table 7 shows calibration results at the upper-watershed sites, including a comparison of measured and simulated flow volumes, suspended-sediment concentrations, and suspended-sediment loads.

Further adjusting of selected sediment-related process parameters was done on the basis of comparison of measured and simulated data for streamflow-gaging station 08181480 Leon Creek at IH 35 (site 15). Calibration of sedimentrelated process parameters for site 15 involved adjustment of PERLND, IMPLND, and RCHRES parameters (appendix 1) for subwatersheds downstream from the upper-watershed sites.

Twenty suspended-sediment samples (and associated streamflows) were collected during 1992-97 and 2007. Most of these samples were collected outside the 1997-2004 simulation period; thus a direct comparison of measured and simulated concentrations, or loads, was not possible. Instead, loads computed from streamflows and suspended-sediment concentrations for the 20 samples were used to develop a regression relation between daily mean streamflow and daily suspended-sediment load at station 08181480 Leon Creek at IH 35 (site 15) (fig. 11). From this relation, estimated daily sediment loads at site 15 were computed for 2001-04. These estimated daily sediment loads were used as targets for HSPF suspended-sediment calibration and simulations at site 15 .

The relation between estimated monthly suspendedsediment loads (computed from regression relation in fig. 11) and HSPF-simulated monthly suspended-sediment loads at Leon Creek at IH 35 (site 15) for the period 2001-04 is shown in figure 12. The HSPF-simulated suspended-sediment load during the period was 77,700 tons compared with an estimate of 74,600 tons from the relation in figure 11 (less than 5-percent difference; coefficient of determination, .869). 


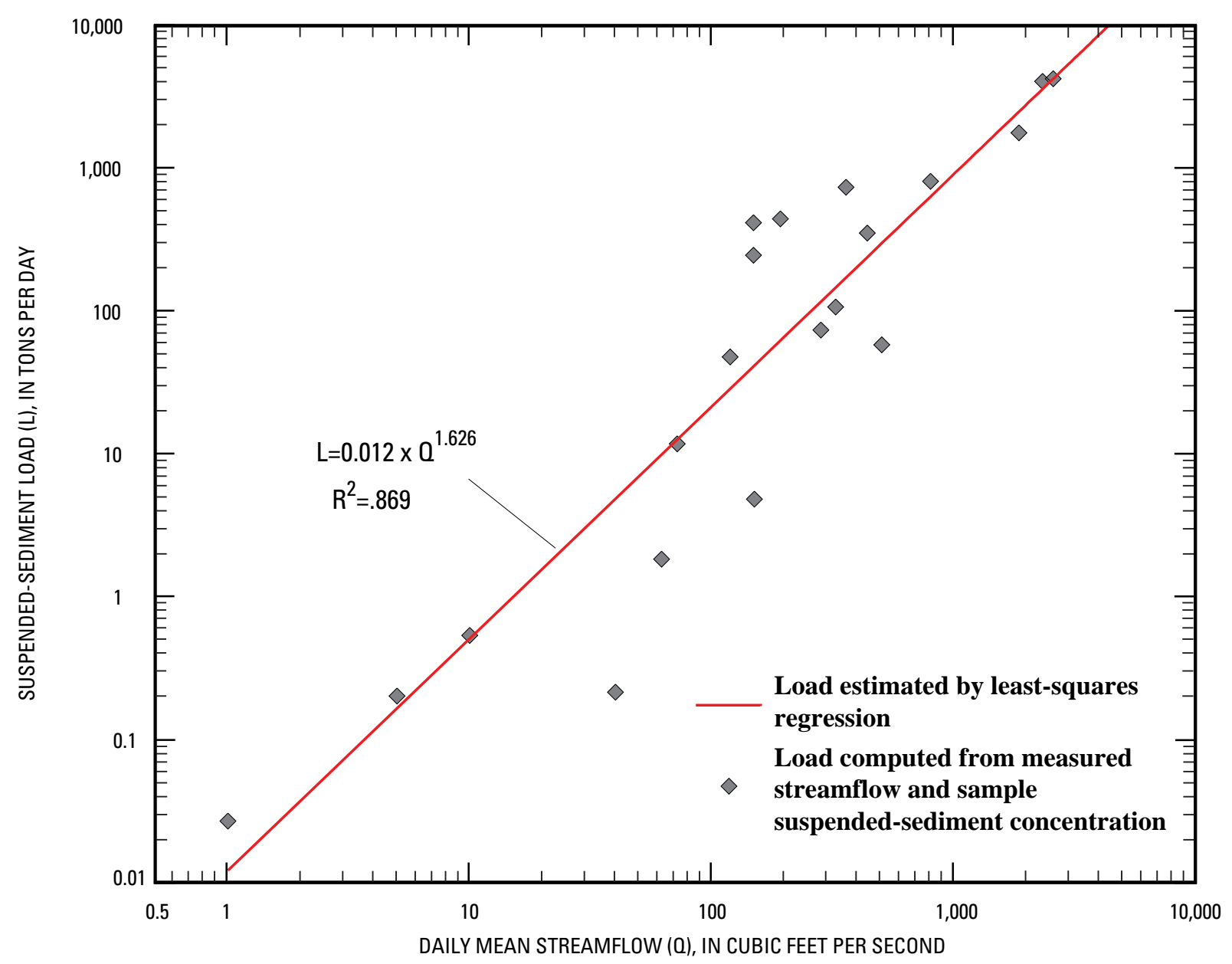

Figure 11. Relation between daily mean streamflow and daily suspended-sediment load based on 20 streamflow-concentration data pairs for station 08181480 Leon Creek at Interstate Highway 35 at San Antonio, Texas, 1992-2007.

July 2002 data were excluded from the relation in figure 12 and in the comparison of simulated and estimated loads for 2001-04 because of major storms and resulting floods then. The HSPF-simulated sediment load for July 2002 was 117,000 tons, greatly exceeding the load for the entire 2001-04 period excluding July 2002. However, that value is unreliable because of the inability of the model to adequately simulate extremely high streamflows, as noted in the "Streamflow" section. The match between HSPF-simulated loads and loads estimated from regression is closer (smaller percentage error) for months of relatively high streamflow and sediment load than for months of relatively low streamflow and sediment load.

\section{Dissolved Ammonia Nitrogen and Dissolved Nitrate Nitrogen}

Nitrogen in outflow of constituents from pervious and impervious land segments is simulated using the PQUAL and IQUAL subroutines (within modules PERLND and IMPLND, respectively). PQUAL and IQUAL simulation routines used for the Leon Creek model include rainfall deposition; accumulation, storage, and washoff of constituents; and simulation of constant interflow and groundwater constituent concentrations.

Instream simulation of nitrogen is accomplished through the RQUAL subroutine of the RCHRES module. RQUAL processes used in the Leon Creek model include ammonia volatilization, denitrification, and ammonia adsorption.

Wet deposition (rainfall) data in the form of weekly ammonia and nitrate concentrations for the period 1992-2004 were obtained from the National Atmospheric Deposition Program stations at Beeville and Sonora, Tex. (fig. 1) (National Atmospheric Deposition Program, 2006). Median concentrations were computed from the sample data $(0.24 \mathrm{mg} / \mathrm{L}$ dissolved ammonia nitrogen and $0.23 \mathrm{mg} / \mathrm{L}$ dissolved nitrate nitrogen) and used as input rainfall concentrations for wet deposition onto PERLND, IMPLND, and RCHRES segments for the HSPF simulations. Dry deposition was not simulated explicitly because local information on dry atmospheric loadings of ammonia and nitrate was not available. However, through calibration of parameters related to accumulation, 


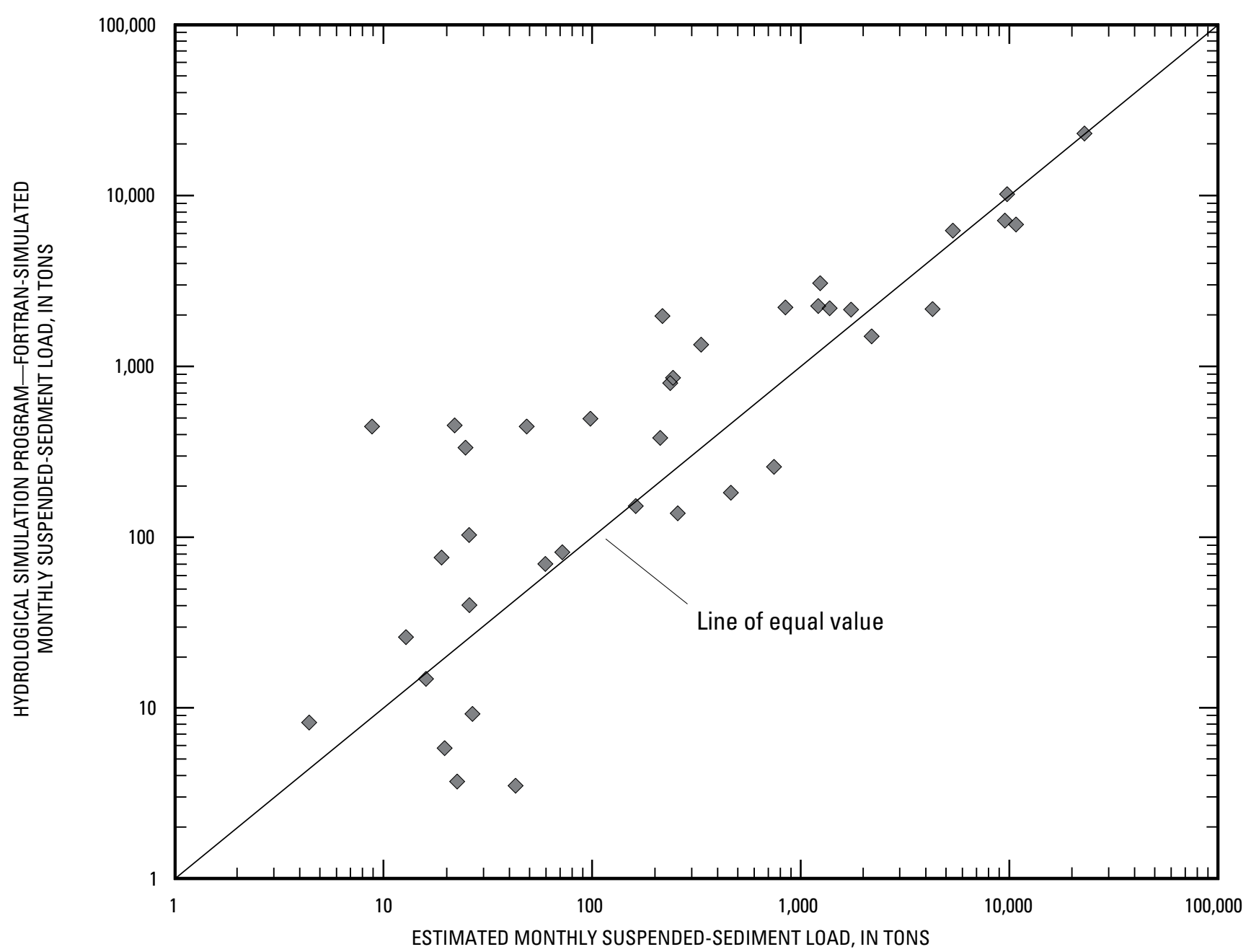

Figure 12. Relation between estimated monthly suspended-sediment loads and Hydrological Simulation Program—FORTRANsimulated suspended-sediment loads for station 08181480 Leon Creek at Interstate Highway 35 at San Antonio, Texas, 2001-04.

storage, and washoff, deposition for nutrients is represented in the general constituent simulations.

The method used to develop initial estimates of dissolved ammonia and nitrate nitrogen accumulation, storage, and washoff parameters for the various PERLNDs and IMPLNDs was similar to the method used to develop soil-erosion and sediment-washoff parameter estimates. Median dissolved ammonia and dissolved nitrate concentrations were computed for each of the four land-use types (residential, industrial, commercial, transportation corridor) from measured runoff concentration data from sites 8-14 that reflect small, urban land-use watersheds. Simulated concentrations from selected PERLNDs and IMPLNDs were compared with median measured runoff concentration values in an iterative series of simulations. Values for parameters related to accumulation, storage, and washoff of ammonia and nitrate were adjusted until simulated concentrations adequately matched median measured concentrations.
These initial parameter values for PERLND and IMPLND processes, as well as parameters related to instream (RCHRES) processes, were further adjusted in a manner similar to that for calibration of the parameters related to sediment transport-that is, by comparing simulated ammonia and nitrate concentrations and loads with measured concentrations and computed streamflow loads for selected stormflows at the upper-watershed sites (4-7) (fig. 4; table 1). Calibration results for dissolved ammonia nitrogen and dissolved nitrate nitrogen for the upper-watershed sites are listed in tables 8 and 9 , respectively.

At station 08181480 Leon Creek at IH 35 (site 15), only two water-quality samples were collected and analyzed by the USGS for dissolved ammonia nitrogen and dissolved nitrate nitrogen during the 1997-2004 period; thus calibration of HSPF parameters related to nutrient simulations in the lower part of the watershed is based on few measured data. Measured and simulated nutrient concentrations are compared in 
Table 6. Simulated 1992-2004 suspended-sediment runoff concentrations from four pervious and impervious land-use types and 1992-2004 medians of measured suspended-sediment runoff concentrations from watersheds that represent the respective land-use types (sites 8-14) for the Hydrological Simulation Program—FORTRAN model of the Leon Creek watershed, Bexar County, Texas.

[in/acre, inches per acre; mg/L, milligrams per liter]

\begin{tabular}{|c|c|c|c|c|c|c|c|c|c|}
\hline \multirow[b]{2}{*}{ Land use } & \multirow[b]{2}{*}{$\begin{array}{l}\text { Percent } \\
\text { pervious }\end{array}$} & \multirow[b]{2}{*}{$\begin{array}{c}\text { Percent } \\
\text { imper- } \\
\text { vious }\end{array}$} & \multicolumn{2}{|c|}{ Simulated pervious } & \multicolumn{2}{|c|}{ Simulated impervious } & \multicolumn{2}{|c|}{ Simulated total } & \multirow{2}{*}{$\begin{array}{c}\text { Median } \\
\text { measured } \\
\text { concentration } \\
(\mathrm{mg} / \mathrm{L})\end{array}$} \\
\hline & & & $\begin{array}{c}\begin{array}{c}\text { Runoff } \\
\text { (in/acre) }\end{array}\end{array}$ & $\begin{array}{l}\text { Concen- } \\
\text { tration } \\
\text { (mg/L) }\end{array}$ & $\begin{array}{c}\text { Runoff } \\
\text { (in/acre) }\end{array}$ & $\begin{array}{l}\text { Concen- } \\
\text { tration } \\
\text { (mg/L) }\end{array}$ & $\begin{array}{c}\text { Runoff } \\
\text { (in/acre) }\end{array}$ & $\begin{array}{c}\text { Concen- } \\
\text { tration } \\
\text { (mg/L) }\end{array}$ & \\
\hline Residential & 48 & 52 & 148 & 214 & 351 & 173 & 258 & 184 & 184 \\
\hline Commercial & 27 & 73 & 148 & 214 & 351 & 196 & 294 & 198 & 198 \\
\hline Industrial & 20 & 80 & 148 & 181 & 351 & 156 & 310 & 157 & 157 \\
\hline Transportation corridor & 16 & 84 & 148 & 219 & 351 & 156 & 328 & 160 & 160 \\
\hline
\end{tabular}

Table 7. Measured and simulated suspended-sediment concentrations and loads at upper-watershed sites for selected stormflows for the Hydrological Simulation Program-FORTRAN model of the Leon Creek watershed, Bexar County, Texas.

[ft $\mathrm{f}^{3} / \mathrm{s}$, cubic feet per second; $\mathrm{mg} / \mathrm{L}$, milligrams per liter]

\begin{tabular}{|c|c|c|c|c|c|c|c|}
\hline \multirow{2}{*}{$\begin{array}{l}\text { Stormflow } \\
\text { date }\end{array}$} & \multicolumn{2}{|c|}{$\begin{array}{l}\text { Daily mean streamflow } \\
\qquad\left(\mathrm{ft}^{3} / \mathrm{s}\right)\end{array}$} & \multicolumn{2}{|c|}{$\begin{array}{l}\text { Suspended-sediment concentration } \\
\qquad(\mathrm{mg} / \mathrm{L})\end{array}$} & \multicolumn{2}{|c|}{$\begin{array}{l}\text { Suspended-sediment load } \\
\text { (tons) }\end{array}$} & \multirow{2}{*}{$\begin{array}{l}\text { Error' in simulated } \\
\text { suspended-sediment load } \\
\text { (percent) }\end{array}$} \\
\hline & Measured & Simulated & Measured & Simulated & Measured & Simulated & \\
\hline \multicolumn{8}{|c|}{08180941 Government Canyon Creek site 2 near Helotes, Texas (site 4) } \\
\hline $\begin{array}{l}\text { August 23, } \\
2004\end{array}$ & 34 & 30 & 185 & 163 & 17.0 & 16.5 & -2.7 \\
\hline \multicolumn{8}{|c|}{08180945 Leon Creek at Scenic Loop Road near Leon Springs, Texas (site 5) } \\
\hline $\begin{array}{l}\text { October } 24, \\
2002\end{array}$ & 87 & 101 & 154 & 119 & 36.1 & 46.8 & 29.5 \\
\hline \multicolumn{8}{|c|}{08181050 Leon Creek at Prue Road at San Antonio, Texas (site 6) } \\
\hline $\begin{array}{l}\text { October 24, } \\
2002\end{array}$ & 253 & 360 & 171 & 169 & 117 & 163 & 39.7 \\
\hline
\end{tabular}

${ }^{1}$ Error $=[($ simulated - measured $) /$ measured $] \mathrm{x} 100$.

table 10. Although the number of samples is small, simulated concentrations of dissolved ammonia nitrogen and dissolved nitrate nitrogen closely matched measured concentrations (within $0.1 \mathrm{mg} / \mathrm{L}$ ).

Average simulated monthly mean dissolved ammonia nitrogen and dissolved nitrate nitrogen concentrations in streamflow at station 08180945 Leon Creek at Scenic Loop Road (site 5) during 1997-2004 were 0.05 and $0.25 \mathrm{mg} / \mathrm{L}$, respectively. The concentration of nitrate is similar to median rainfall concentrations of nitrate $(0.23 \mathrm{mg} / \mathrm{L})$. Streamflow concentrations of ammonia are much lower than rainfall concentrations because ammonia in rainfall and runoff quickly undergoes volatilization to nitrite and nitrate (Bowie and others, 1985). At station 08181480 Leon Creek at IH 35 (site 15 ), average simulated monthly mean concentrations of dissolved ammonia and nitrate concentrations during 1997-2004 were 0.03 and $0.37 \mathrm{mg} / \mathrm{L}$, respectively. Simulated concentrations of dissolved ammonia and nitrate in streamflow were relatively low at most stream reach outlets. However, dissolved nitrate concentrations were much greater at the most downstream reach (RCHRES 109) because of the inflow of wastewater. The average nitrate concentration associated with the wastewater was $15 \mathrm{mg} / \mathrm{L}$. This inflow greatly increases nitrate concentrations at the mouth of Leon Creek. The average simulated monthly mean concentration of nitrate at RCHRES 109 during 1997-2004 was 7.4 mg/L. For comparison, just 
Table 8. Measured and simulated dissolved ammonia nitrogen concentrations and loads at upper-watershed sites for selected stormflows for the Hydrological Simulation Program—FORTRAN model of the Leon Creek watershed, Bexar County, Texas.

[ft³/s, cubic feet per second; mg/L, milligrams per liter; lb, pounds; <, less than]

\begin{tabular}{|c|c|c|c|c|c|c|c|}
\hline \multirow[t]{2}{*}{ Stormflow date } & \multicolumn{2}{|c|}{$\begin{array}{l}\text { Daily mean streamflow } \\
\qquad\left(\mathrm{ft}^{3} / \mathrm{s}\right)\end{array}$} & \multicolumn{2}{|c|}{$\begin{array}{c}\text { Dissolved ammonia } \\
\text { nitrogen concentration } \\
\text { (mg/L) }\end{array}$} & \multicolumn{2}{|c|}{$\begin{array}{c}\text { Dissolved ammonia } \\
\text { nitrogen load } \\
\text { (lb) }\end{array}$} & \multirow{2}{*}{$\begin{array}{l}\text { Error }{ }^{1} \text { in simulated dissolved } \\
\text { ammonia nitrogen load } \\
\text { (percent) }\end{array}$} \\
\hline & Measured & Simulated & Measured & Simulated & Measured & Simulated & \\
\hline \multicolumn{8}{|c|}{08180941 Government Canyon Creek site 2 near Helotes, Texas (site 4) } \\
\hline August 23, 2004 & 34 & 30 & $<0.04$ & 0.03 & 7.3 & 5.3 & -28 \\
\hline October 24,2002 & 87 & 101 & $<.04$ & .04 & 19 & 27 & 42 \\
\hline \multicolumn{8}{|c|}{08181050 Leon Creek at Prue Road at San Antonio, Texas (site 6) } \\
\hline October 24,2002 & 253 & 360 & $<.04$ & .05 & 55 & 96 & 75 \\
\hline
\end{tabular}

1 Error $=[($ simulated - measured $) /$ measured $] \times 100$.

Table 9. Measured and simulated dissolved nitrate nitrogen concentrations and loads at upper-watershed sites for selected stormflows for the Hydrological Simulation Program-FORTRAN model of the Leon Creek watershed, Bexar County, Texas.

[ft $3 / \mathrm{s}$, cubic feet per second; $\mathrm{mg} / \mathrm{L}$, milligrams per liter; lb, pounds]

\begin{tabular}{|c|c|c|c|c|c|c|c|}
\hline Stormflow date & \multicolumn{2}{|c|}{$\begin{array}{l}\text { Daily mean streamflow } \\
\left(\mathrm{ft}^{3} / \mathrm{s}\right)\end{array}$} & \multicolumn{2}{|c|}{$\begin{array}{c}\text { Dissolved nitrate } \\
\text { nitrogen concentration } \\
\text { (mg/L) }\end{array}$} & \multicolumn{2}{|c|}{$\begin{array}{l}\text { Dissolved nitrate } \\
\text { nitrogen load } \\
\text { (lb) }\end{array}$} & $\begin{array}{l}\text { Error }{ }^{1} \text { in simulated dissolved } \\
\text { nitrate nitrogen load } \\
\text { (percent) }\end{array}$ \\
\hline \multicolumn{8}{|c|}{08180941 Government Canyon Creek site 2 near Helotes, Texas (site 4) } \\
\hline August 23, 2004 & 34 & 30 & 0.38 & 0.10 & 70 & 24 & -66 \\
\hline October 24, 2002 & 87 & 101 & .10 & .11 & 47 & 78 & 66 \\
\hline \multicolumn{8}{|c|}{08181050 Leon Creek at Prue Road at San Antonio, Texas (site 6) } \\
\hline October 24, 2002 & 253 & 360 & .34 & .22 & 464 & 420 & -9.5 \\
\hline
\end{tabular}

${ }^{1}$ Error $=[($ simulated - measured $) /$ measured $] \times 100$.

Table 10. Measured and simulated concentrations of dissolved ammonia nitrogen and dissolved nitrate nitrogen for selected stormflows at station 08181480 Leon Creek at Interstate Highway 35 at San Antonio, Texas.

[ft ${ }^{3} / \mathrm{s}$, cubic feet per second; $\mathrm{mg} / \mathrm{L}$, milligrams per liter]

\begin{tabular}{|c|c|c|c|c|c|c|}
\hline Stormflow date & \multicolumn{2}{|c|}{$\begin{array}{l}\text { Daily mean streamflow } \\
\qquad\left(\mathrm{ft}^{3} / \mathrm{s}\right)\end{array}$} & \multicolumn{2}{|c|}{$\begin{array}{c}\text { Dissolved ammonia nitrogen } \\
\text { concentration } \\
(\mathrm{mg} / \mathrm{L})\end{array}$} & \multicolumn{2}{|c|}{$\begin{array}{c}\text { Dissolved nitrate nitrogen } \\
\text { concentration } \\
\text { (mg/L) }\end{array}$} \\
\hline April 2, 1997 & 113 & 442 & 0.04 & 0.04 & 0.41 & 0.51 \\
\hline April 26, 1997 & 160 & 123 & .11 & .12 & .79 & .63 \\
\hline
\end{tabular}


upstream from the recycled wastewater inflow at the outlet of RCHRES 108 , the simulated average monthly mean concentration of nitrate was $0.36 \mathrm{mg} / \mathrm{L}$.

\section{Dissolved and Total Lead and Dissolved and Total Zinc}

Lead and zinc transport from land surfaces is simulated by accumulation and washoff of the dissolved form and the constituent associated with sediment. These processes are accomplished by the PQUAL and IQUAL modules (within PERLND and IMPLND modules, respectively). Interflow and groundwater inflow of lead and zinc are simulated by input of constant concentration values assigned to simulated interflow and groundwater inflow. Instream changes in metals concentrations are simulated by the GQUAL module within the RCHRES module. GQUAL simulates dissolved constituent concentrations and concentrations associated with sand, silt, and clay. Process-related parameters affecting distribution of metals between the dissolved phase and sediment adsorption include partitioning coefficients and adsorption/desorption rate parameters (Allison and Allison, 2005). Because of the availability of some sample data that included analyses of dissolved and total metal concentrations, initial estimates of these parameters could be adjusted to better calibrate simulated dissolved and total lead and zinc concentrations to measured values.

Initial estimates for daily accumulation of lead and zinc onto land surfaces were values from Paode and others (1998). Calibration was accomplished by comparing simulated concentrations and loads to measured concentrations and loads at the upper-watershed sites (tables 11, 12). During the simulation period (1997-2004), 31 samples for lead and 35 samples for zinc were collected and analyzed from the four upperwatershed sites. Most of the samples were analyzed for the total constituent (dissolved plus adsorbed to sediment). About one-half of the samples also included analyses of the dissolved phase of the constituent.

Generally, simulated lead concentrations compared adequately with measured concentrations in 1997-2004 stormflows at the upper-watershed sites (table 11). Process-related parameters controlling accumulation and washoff of lead were relatively consistent for all four sites. Accumulation rates for the subwatershed monitored at station 08180941 Government Canyon Creek near Helotes (site 4) (fig. 4; table 1) were slightly lower than the rates for subwatersheds monitored at the other three stations because that subwatershed includes relatively more undeveloped land (including a State natural area and park). Most measured dissolved lead concentrations for the four upper-watershed sites were less than or near the laboratory reporting level of 0.08 microgram per liter $(\mu \mathrm{g} / \mathrm{L})$; and the median simulated dissolved lead concentration for those sites was $0.05 \mu \mathrm{g} / \mathrm{L}$. The median measured total lead concentration for the four sites was $2.9 \mu \mathrm{g} / \mathrm{L}$, and the median simulated concentration was $4.2 \mu \mathrm{g} / \mathrm{L}$.

Overall, simulated total zinc concentrations for the upper-watershed sites compared adequately with measured data (table 12). However, dissolved zinc was under-simulated. Process-related parameters for accumulation and washoff of zinc were consistent for most of the upstream subwatersheds. The exception is subwatershed 10 (fig. 5), which is monitored by station 08180945 Leon Creek at Scenic Loop Road (site 5) (fig. 4) at the outlet of RCHRES 10. Analyses from six stormflow samples (collected during 2002-07) yielded total and dissolved zinc concentrations that were roughly an order of magnitude greater than measured concentrations from the other upper-watershed sites (collected during 1997-2004). The reason for greater zinc concentrations in subwatershed 10 is not known. Monitoring station 08181050 Leon Creek at Prue Road (site 6) is at the outlet of RCHRES 28 downstream from RCHRES 10. Samples collected at site 6 had lower zinc concentrations than samples collected at site 5; and measured concentrations at site 6 were more similar to measured concentrations at sites 4 and 7 than to those at site 5. Therefore zinc accumulation and washoff parameters were adjusted to simulate higher zinc runoff concentrations from RCHRES 10 and associated PERLNDs and IMPLNDs than from downstream RCHRES and associated PERLNDs and IMPLNDs. The median measured dissolved zinc concentration for the four sites was $2.2 \mu \mathrm{g} / \mathrm{L}$, and the median simulated concentration was $0.38 \mu \mathrm{g} / \mathrm{L}$. The median measured total zinc concentration for the four sites was less than $25 \mu \mathrm{g} / \mathrm{L}$, and the median simulated concentration was $9.9 \mu \mathrm{g} / \mathrm{L}$.

At the most downstream streamflow station $(08181480$ Leon Creek at IH 35) (site 15), only three samples were collected and analyzed for lead and zinc during 1997-2002 (all in 1997). The samples were analyzed only for the total form of the constituents. Simulated total lead and total zinc concentrations were much less than measured concentrations for two samples collected in April 1997 (table 13). For the October 1997 sample, the simulated total lead concentration closely matched the measured concentration, but the simulated total zinc concentration was much greater than the measured concentration.

Because of the relatively large differences between most of the measured and simulated values and the few data available for 1997-2002, additional sample data for site 15 outside the simulation period were analyzed. Seven additional stormflow samples collected and analyzed for total lead and total zinc during 1993-96 were available. Because simulated total lead and total zinc concentrations were not available for comparison with measured concentrations from these seven samples, median concentrations of all 10 available measured sample concentrations for 1993-97 are compared with median simulated concentrations for the three 1997 stormflows (table 13). The matches between measured and simulated still are not particularly close: The median measured total lead concentration for the 1993-97 stormflow data is $6.5 \mu \mathrm{g} / \mathrm{L}$, and the median simulated total lead concentration for the three 1997 stormflows is $14 \mu \mathrm{g} / \mathrm{L}$. The median measured total zinc concentration for the 1993-97 stormflow data is $25 \mu \mathrm{g} / \mathrm{L}$, and the median simulated total zinc concentration for the three 1997 stormflows is $47 \mu \mathrm{g} / \mathrm{L}$. 
Table 11. Measured and simulated concentrations of dissolved and total lead at upper-watershed sites for selected stormflows for the Hydrological Simulation Program—FORTRAN model of the Leon Creek watershed, Bexar County, Texas.

[ft $3 / \mathrm{s}$, cubic feet per second; $\mu \mathrm{g} / \mathrm{L}$, micrograms per liter; --, no data or not applicable; <, less than; E, estimated $\left.{ }^{1}\right]$

\begin{tabular}{|c|c|c|c|c|c|c|}
\hline \multirow{2}{*}{ Stormflow date } & \multicolumn{2}{|c|}{$\begin{array}{c}\text { Daily mean streamflow } \\
\left(\mathrm{ft}^{3} / \mathbf{s}\right)\end{array}$} & \multicolumn{2}{|c|}{$\begin{array}{c}\text { Total lead concentration } \\
(\mu \mathrm{g} / \mathrm{L})\end{array}$} & \multicolumn{2}{|c|}{$\begin{array}{c}\text { Dissolved lead concentration } \\
(\mu \mathrm{g} / \mathrm{L})\end{array}$} \\
\hline & Measured & Simulated & Measured & Simulated & Measured & Simulated \\
\hline \multicolumn{7}{|c|}{08180941 Government Canyon Creek site 2 near Helotes, Texas (site 4) } \\
\hline June 23, 1997 & -- & 152 & $<1.0$ & 2.7 & -- & 0.08 \\
\hline June 24, 1997 & -- & 57 & $<1.0$ & 2.0 & -- & .10 \\
\hline March 16, 1998 & -- & 26 & 3.3 & 3.9 & -- & .08 \\
\hline August 22, 1998 & -- & 2.8 & 1.3 & 5.1 & -- & .06 \\
\hline October 17, 1998 & -- & 645 & 9.7 & 17 & -- & .01 \\
\hline October 23, 2000 & 557 & 659 & 16.7 & 14 & -- & .01 \\
\hline July 2,2002 & -- & 2,020 & 2.9 & 5.8 & 0.13 & .01 \\
\hline June 28, 2004 & 3.8 & 37 & 1.4 & 6.7 & $<.08$ & .04 \\
\hline August 23, 2004 & 43 & 30 & 3.4 & 4.5 & $<.08$ & .05 \\
\hline Median concentration & & & 2.2 & 5.1 & $<.08$ & .05 \\
\hline
\end{tabular}

08180945 Leon Creek at Scenic Loop Road near Leon Springs, Texas (site 5)

\begin{tabular}{|c|c|c|c|c|c|c|}
\hline July 1,2002 & 462 & 367 & 2.4 & 8.6 & $<.08$ & .02 \\
\hline October 24,2002 & 87 & 101 & 3.4 & 3.8 & E.05 & .11 \\
\hline Median concentration & & & 2.9 & 6.2 & $<.08$ & .06 \\
\hline
\end{tabular}

\begin{tabular}{|c|c|c|c|c|c|c|}
\hline \multicolumn{7}{|c|}{08181050 Leon Creek at Prue Road at San Antonio, Texas (site 6) } \\
\hline March 14, 2001 & 1.5 & 1.7 & 4.4 & 1.1 & .09 & .05 \\
\hline October 132001 & 253 & 351 & 4.2 & 3.4 & $<.08$ & .02 \\
\hline November 15, 2001 & 1,430 & 983 & 10 & 11 & E.04 & .03 \\
\hline April 7, 2002 & 3.7 & 14 & 2.4 & 2.2 & .09 & .03 \\
\hline June 30, 2002 & 129 & 478 & 2.3 & 5.2 & $<.08$ & .02 \\
\hline October 24, 2002 & 253 & 360 & 2.0 & 3.4 & $<.08$ & .03 \\
\hline February 20, 2003 & 6.8 & 29 & 2.2 & 1.9 & .12 & .04 \\
\hline May 1,2004 & -- & 6.3 & 1.8 & 1.8 & .06 & .04 \\
\hline Median concentration & & & 2.4 & 2.8 & $<.08$ & .03 \\
\hline \multicolumn{7}{|c|}{08181400 Helotes Creek at Helotes, Texas (site 7) } \\
\hline April 4, 1997 & 14 & 23 & 6.6 & 1.4 & -- & .09 \\
\hline June 22, 1997 & 1,040 & 918 & 6.1 & 13 & -- & .07 \\
\hline June 25, 1997 & 149 & 134 & $<1.0$ & 1.8 & -- & .09 \\
\hline January 6, 1998 & .1 & 7.6 & 1.6 & 2.2 & -- & .12 \\
\hline August 22, 1998 & 2.4 & 46 & 4.2 & 4.4 & -- & .07 \\
\hline October 17, 1998 & 1,340 & 688 & 9.8 & 14 & -- & .07 \\
\hline June 21, 1999 & 12.6 & 12 & 8.9 & 3.3 & -- & .10 \\
\hline June 10,2000 & .5 & 15 & 6.1 & 2.7 & -- & .07 \\
\hline July 1, 2002 & 580 & 919 & 1.9 & 13 & $<.08$ & .29 \\
\hline July 2, 2002 & 641 & 2,150 & 28 & 9.3 & E.07 & .10 \\
\hline October 24, 2002 & 61 & 178 & $<1.0$ & 5.1 & $<.08$ & .05 \\
\hline July 5, 2003 & 6.2 & 34 & 2.1 & 4.2 & .24 & .01 \\
\hline Median concentration & & & 5.2 & 4.3 & $<.08$ & .08 \\
\hline
\end{tabular}

${ }^{1}$ Estimated concentrations are concentrations measured between the laboratory reporting level and the long-term method detection level (Childress and others, 1999). 
Table 12. Measured and simulated concentrations of dissolved and total zinc at upper-watershed sites for selected stormflows for the Hydrological Simulation Program—FORTRAN model of the Leon Creek watershed, Bexar County, Texas.

[ft $3 / \mathrm{s}$, cubic feet per second; $\mu \mathrm{g} / \mathrm{L}$, micrograms per liter; --, no data or not applicable; <, less than]

\begin{tabular}{|c|c|c|c|c|c|c|}
\hline \multirow[t]{2}{*}{ Stormflow date } & \multicolumn{2}{|c|}{$\begin{array}{c}\text { Daily mean streamflow } \\
\left(\mathbf{f t}^{3} / \mathbf{s}\right)\end{array}$} & \multicolumn{2}{|c|}{$\begin{array}{c}\text { Total zinc concentration } \\
(\mu \mathrm{g} / \mathrm{L})\end{array}$} & \multicolumn{2}{|c|}{$\begin{array}{c}\text { Dissolved zinc concentration } \\
(\mu \mathrm{g} / \mathrm{L})\end{array}$} \\
\hline & Measured & Simulated & Measured & Simulated & Measured & Simulated \\
\hline \multicolumn{7}{|c|}{08180941 Government Canyon Creek site 2 near Helotes, Texas (site 4) } \\
\hline June 23, 1997 & -- & 152 & $<10$ & 5.0 & -- & 0.29 \\
\hline June 24, 1997 & -- & 57 & $<10$ & 2.9 & -- & .29 \\
\hline March 16, 1998 & -- & 26 & 10 & 8.0 & -- & .49 \\
\hline August 22, 1998 & -- & 2.8 & $<10$ & 7.0 & -- & .29 \\
\hline October 17,1998 & -- & 645 & 30 & 36 & -- & .19 \\
\hline October 23, 2000 & 557 & 659 & 25 & 33 & -- & .20 \\
\hline July 2,2002 & -- & 2,020 & $<25$ & 13 & 1.6 & .10 \\
\hline June 28, 2004 & 3.8 & 37 & 5 & 24 & .70 & .43 \\
\hline August 23, 2004 & 42 & 30 & 9 & 9.9 & .70 & .38 \\
\hline Median concentration & & & $<10$ & 9.9 & .70 & .30 \\
\hline \multicolumn{7}{|c|}{08180945 Leon Creek at Scenic Loop Road near Leon Springs, Texas (site 5) } \\
\hline July 1,2002 & 462 & 367 & 250 & 240 & 30 & 3.1 \\
\hline October 24, 2002 & 87 & 101 & 496 & 220 & 46 & 16 \\
\hline November 16-17, 2004 & -- & & 649 & & 36 & \\
\hline May 6, 2006 & -- & -- & 834 & -- & 100 & -- \\
\hline March 26, 2007 & -- & -- & -- & -- & 155 & -- \\
\hline March 30, 2007 & -- & -- & 502 & -- & 130 & -- \\
\hline Median concentration & & & 375 & 230 & 38 & 9.4 \\
\hline \multicolumn{7}{|c|}{08181050 Leon Creek at Prue Road at San Antonio, Texas (site 6) } \\
\hline March 14, 2001 & 1.5 & 1.7 & -- & 1.3 & 4.3 & .48 \\
\hline October 132001 & 253 & 351 & -- & 22 & 1.5 & .57 \\
\hline November 15, 2001 & 1,430 & 983 & -- & 46 & 1.0 & .78 \\
\hline April 7, 2002 & 3.7 & 14 & -- & 36 & 3.2 & 1.8 \\
\hline June 30, 2002 & 129 & 478 & $<25$ & 16 & 1.6 & .29 \\
\hline October 24, 2002 & 253 & 360 & $<25$ & 24 & 1.0 & .61 \\
\hline February 20, 2003 & 6.8 & 28.7 & $<25$ & 3.4 & 2.3 & .41 \\
\hline May 1,2004 & -- & 6.3 & 11 & 2.6 & 2.2 & .45 \\
\hline Median concentration & & & $<25$ & 16 & 2.2 & .48 \\
\hline \multicolumn{7}{|c|}{08181400 Helotes Creek at Helotes, Texas (site 7) } \\
\hline April 4, 1997 & 14 & 23 & 20 & 1.7 & -- & .27 \\
\hline June 22, 1997 & 1,040 & 918 & 20 & 26 & -- & 1.0 \\
\hline June 25, 1997 & 149 & 134 & $<10$ & 2.6 & -- & .28 \\
\hline January 6, 1998 & .1 & 7.6 & 20 & 1.9 & -- & .29 \\
\hline August 22, 1998 & 2.4 & 46 & $<10$ & 4.6 & -- & .28 \\
\hline October 17, 1998 & 1,340 & 688 & 30 & 29 & -- & 1.17 \\
\hline June 21, 1999 & 13 & 12 & 21 & 3.1 & -- & .28 \\
\hline June 10, 2000 & .5 & 15 & 6.1 & 2.5 & -- & .25 \\
\hline July 1, 2002 & 580 & 919 & 17 & 24 & 1.2 & 1.69 \\
\hline July 2, 2002 & 641 & 2,150 & 58 & 11 & $<1.0$ & .14 \\
\hline October 24, 2002 & 60 & 178 & $<25$ & 5.3 & 2.2 & .87 \\
\hline July 5, 2003 & 6.2 & 34 & 8 & 3.8 & 2.7 & .22 \\
\hline Median concentration & & & 5.2 & 4.2 & 1.7 & .28 \\
\hline
\end{tabular}


Table 13. Measured and simulated concentrations of total lead and total zinc for selected stormflows at station 08181480 Leon Creek at Interstate Highway 35 at San Antonio, Texas.

[ft 3 /s, cubic feet per second; $\mu \mathrm{g} / \mathrm{L}$, micrograms per liter; <, less than. Median simulated concentrations for three 1997 stormflows and median measured concentrations for 1993-97 stormflows shown in bold for comparison.]

\begin{tabular}{|c|c|c|c|c|c|c|}
\hline \multirow[t]{2}{*}{ Stormflow date } & \multicolumn{2}{|c|}{$\begin{array}{c}\text { Daily mean streamflow } \\
\left(\mathrm{ft}^{3} / \mathrm{s}\right)\end{array}$} & \multicolumn{2}{|c|}{$\begin{array}{c}\text { Total lead concentration } \\
(\mu \mathrm{g} / \mathrm{L})\end{array}$} & \multicolumn{2}{|c|}{$\begin{array}{c}\text { Total zinc concentration } \\
(\mu \mathrm{g} / \mathrm{L})\end{array}$} \\
\hline & Measured & Simulated & Measured & Simulated & Measured & Simulated \\
\hline April 2, 1997 & 113 & 442 & 37 & 7.5 & 120 & 27 \\
\hline April 26, 1997 & 160 & 123 & 64 & 28 & 190 & 56 \\
\hline October 10, 1997 & 108 & 493 & 12 & 14 & $<10$ & 47 \\
\hline \multicolumn{3}{|c|}{$\begin{array}{l}\text { Median measured stormflow-sample } \\
\text { concentration (and number of } \\
\text { samples) for 1993-97 }\end{array}$} & $6.5(10)$ & -- & $25(10)$ & -- \\
\hline
\end{tabular}

Besides the 10 stormflow samples for total lead and total zinc collected at station 08181480 Leon Creek at IH 35 (site 15) during 1993-97, nine base-flow samples also were collected and analyzed for total lead and total zinc during 1992-94. Summary statistics for these samples are listed in table 14. The median measured total lead concentration was $1.0 \mu \mathrm{g} / \mathrm{L}$, and the median measured total zinc concentration was $10 \mu \mathrm{g} / \mathrm{L}$. These median concentrations were used as target values for calibration of simulated total lead and total zinc during base-flow periods.

Summary statistics for simulated daily mean total lead and total zinc concentrations for base-flow periods at site 15 during 1997-2004 are listed in table 15. The summary statistics were compiled for 2,041 days when the daily mean streamflow at site 15 was less than 20 cubic feet per second. For these base-flow days, average and median concentrations of simulated total lead (1.3 and $0.96 \mathrm{mg} / \mathrm{L}$, respectively) and total zinc (13 and $9.8 \mathrm{mg} / \mathrm{L}$, respectively) match the corresponding measured concentrations (table 14) closely, although maximums not as well.

Table 14. Summary statistics for measured streamflow and concentrations of total lead and total zinc for nine base-flow samples collected during 1992-94 at station 08181480 Leon Creek at Interstate Highway 35 at San Antonio, Texas.

[ $\mathrm{ft}^{3} / \mathrm{s}$, cubic feet per second; $\mu \mathrm{g} / \mathrm{L}$, micrograms per liter; $<$, less than]

\begin{tabular}{cccccc}
\hline $\begin{array}{c}\text { Streamflow } \\
\text { or } \\
\text { constituent }\end{array}$ & $\begin{array}{c}\text { Num- } \\
\text { ber of } \\
\text { samples }\end{array}$ & Average & Median & Maximum & Minimum \\
\hline $\begin{array}{c}\text { Streamflow } \\
\left(\mathrm{ft}^{3} / \mathrm{s}\right)\end{array}$ & 9 & 13 & 10 & 27 & 3.3 \\
$\begin{array}{c}\text { Total lead } \\
(\mu \mathrm{g} / \mathrm{L})\end{array}$ & 9 & $<1.0$ & 1.0 & 1.0 & $<1.0$ \\
$\begin{array}{c}\text { Total zinc } \\
(\mu \mathrm{g} / \mathrm{L})\end{array}$ & 9 & $<14$ & 10 & 30 & $<10$ \\
\hline
\end{tabular}

As a result of the water-quality calibration process, a set of water-quality-related parameters was developed for the Leon Creek model. A summary of the calibrated parameter values for the Leon Creek model is in table 16.

\section{Simulation of Constituent Loads and Yields}

To demonstrate an application of the Leon Creek HSPF model, streamflow constituent loads and yields for three selected constituents were simulated: suspended sediment, dissolved nitrate nitrogen, and total lead. Mean annual (19972004) streamflow and annual constituent loads and yields were simulated at the mouth of Leon Creek (outlet of the watershed). These results are listed in table 17.

The annual suspended-sediment load ranged from 7,900 tons in 2003 (year of lowest annual streamflow) to 163,000 tons in 2002 (year of highest annual streamflow). The average load was 51,800 tons per year. The corresponding annual suspended-sediment yields ranged from 0.05 ton per acre in

Table 15. Summary statistics for simulated daily mean total lead and total zinc concentrations for base-flow periods ${ }^{1}$ at station 08181480 Leon Creek at Interstate Highway 35 at San Antonio, Texas, 1997-2004.

$\left[\mu \mathrm{g} / \mathrm{L}\right.$, micrograms per liter; $\mathrm{ft}^{3} / \mathrm{s}$, cubic feet per second]

\begin{tabular}{cccccc}
\hline Constituent & $\begin{array}{c}\text { Number } \\
\text { of days }\end{array}$ & Average & Median & Maximum & Minimum \\
\hline $\begin{array}{c}\text { Total lead } \\
(\mu \mathrm{g} / \mathrm{L})\end{array}$ & 2,041 & 1.3 & 0.96 & 20 & 0.54 \\
$\begin{array}{c}\text { Total zinc } \\
(\mu \mathrm{g} / \mathrm{L})\end{array}$ & 2,041 & 13 & 9.8 & 167 & .58 \\
\hline
\end{tabular}

${ }^{1}$ Base-flow periods are days when simulated daily mean streamflow is less than $20 \mathrm{ft}^{3} / \mathrm{s}$; during 1997-2004, 2,041 of 2,922 days met this criterion. 
Table 16. Summary of calibrated values for selected water-quality parameters for the Hydrological Simulation Program-FORTRAN model of the Leon Creek watershed, Bexar County, Texas, 1997-2004.

[RCHRES, stream reach; --, none; PERLND, pervious land surface; ${ }^{\circ} \mathrm{C}$, degrees Celsius; IMPLND, impervious land surface]

\begin{tabular}{|c|c|c|c|c|}
\hline Parameter & Model module & Description & Value & Unit \\
\hline CFSAEX & RCHRES & $\begin{array}{l}\text { Correction factor for solar radiation, the fraction of RCHRES } \\
\text { surface exposed to solar radiation }\end{array}$ & 0.45 & -- \\
\hline KATRAD & RCHRES & Longwave radiation coefficient & 9.0 & -- \\
\hline KCOND & RCHRES & Conduction-convection heat transport coefficient & 3.0 & -- \\
\hline
\end{tabular}

\begin{tabular}{|c|c|c|c|c|}
\hline \multicolumn{5}{|c|}{ Dissolved oxygen } \\
\hline IDOXP & PERLND & Concentration of dissolved oxygen in interflow & $5.0-8.0$ & milligram/liter \\
\hline ADOXP & PERLND & Concentration of dissolved oxygen in base flow & $4.0-8.0$ & milligram/liter \\
\hline KBOD20 & RCHRES & Unit biochemical oxygen demand decay rate at $20^{\circ} \mathrm{C}$ & .004 & /hour \\
\hline KODSET & RCHRES & Rate of biochemical oxygen demand settling & .027 & foot/hour \\
\hline BENOD & RCHRES & Benthal oxygen demand at $20^{\circ} \mathrm{C}$ & 75 & $\begin{array}{l}\text { milligram/square meter- } \\
\text { hour }\end{array}$ \\
\hline $\operatorname{BRBOD}(1)$ & RCHRES & $\begin{array}{l}\text { Benthal release rate of biochemical oxygen demand under } \\
\text { anaerobic conditions }\end{array}$ & .001 & $\begin{array}{l}\text { milligram/square meter- } \\
\text { hour }\end{array}$ \\
\hline $\operatorname{BRBOD}(2)$ & RCHRES & $\begin{array}{l}\text { Increment to benthal release rate of biochemical oxygen } \\
\text { demand under anaerobic conditions }\end{array}$ & .001 & $\begin{array}{l}\text { milligram/square meter- } \\
\text { hour }\end{array}$ \\
\hline KRER & PERLND & Coefficient of soil-detachment equation & $.01-.30$ & complex \\
\hline JRER & PERLND & Exponent of soil-detachment equation & $2.0-2.5$ & complex \\
\hline KSER & PERLND & Coefficient of detached-sediment washoff equation & $.1-.8$ & complex \\
\hline JSER & PERLND & Exponent of detached-sediment washoff equation & 2.0 & complex \\
\hline AFFX & PERLND & $\begin{array}{l}\text { Fraction by which detached sediment decreases daily } \\
\text { through soil compaction }\end{array}$ & $.01-.02$ & 1/day \\
\hline COVER & PERLND & $\begin{array}{l}\text { Fraction of land surface shielded by vegetation or mulch } \\
\text { from erosion by direct rainfall impact }\end{array}$ & $.10-.85$ & -- \\
\hline NVSI & PERLND & $\begin{array}{l}\text { Rate at which sediment enters detached-sediment storage } \\
\text { from atmosphere }\end{array}$ & $.4-.5$ & pound/acre-day \\
\hline M (silt) & RCHRES & Erodibility coefficient of sediment & .005 & pound/square foot-day \\
\hline M (clay) & RCHRES & Erodibility coefficient of sediment & .01 & pound/square foot-day \\
\hline $\begin{array}{l}\text { W (silt and } \\
\text { clay) }\end{array}$ & RCHRES & Settling velocity of sediment particle in still water & $.00005-.0005$ & inch/second \\
\hline TAUCD (silt) & RCHRES & Critical bed shear stress for sediment deposition & $.08-.12$ & pound/square foot \\
\hline TAUCS (silt) & RCHRES & Critical bed shear stress for sediment scour & $.24-.28$ & pound/square foot \\
\hline
\end{tabular}


Table 16. Summary of calibrated values for selected water-quality parameters for the Hydrological Simulation Program—FORTRAN model of the Leon Creek watershed, Bexar County, Texas, 1997-2004-Continued.

\begin{tabular}{ccccc}
\hline Parameter & Model module & Description & Value & Unit \\
\hline \multicolumn{1}{c}{$\begin{array}{c}\text { TAUCD } \\
\text { (clay) }\end{array}$} & RCHRES & Critical bed shear stress for sediment deposition & $0.07-0.10$ & pound/square foot \\
$\begin{array}{c}\text { TAUCS } \\
\text { (clay) }\end{array}$ & RCHRES & Critical bed shear stress for sediment scour & $.20-.24$ & pound/square foot \\
\hline
\end{tabular}

\begin{tabular}{|c|c|c|c|c|}
\hline \multicolumn{5}{|c|}{ Dissolved ammonia nitrogen } \\
\hline ACQOP & $\begin{array}{l}\text { PERLND or } \\
\text { IMPLND }\end{array}$ & Accumulation rate of constituent on surface & $.0025-.012$ & pound/acre-day \\
\hline SQOLIM & $\begin{array}{l}\text { PERLND or } \\
\text { IMPLND }\end{array}$ & Maximum storage of constituent on surface & $.01-.12$ & pound/acre \\
\hline WSQOP & PERLND & $\begin{array}{l}\text { Rate of surface runoff to remove } 90 \text { percent of stored con- } \\
\text { stituent in } 1 \text { hour }\end{array}$ & $.5-.7$ & inch/acre \\
\hline
\end{tabular}

\begin{tabular}{|c|c|c|c|c|}
\hline \multicolumn{5}{|c|}{ Dissolved nitrate nitrogen } \\
\hline ACQOP & $\begin{array}{l}\text { PERLND or } \\
\text { IMPLND }\end{array}$ & Accumulation rate of constituent on surface & $.003-.012$ & pound/acre-day \\
\hline WSQOP & PERLND & $\begin{array}{l}\text { Rate of surface runoff to remove } 90 \text { percent of stored con- } \\
\text { stituent in } 1 \text { hour }\end{array}$ & $.5-.8$ & inch/acre \\
\hline
\end{tabular}

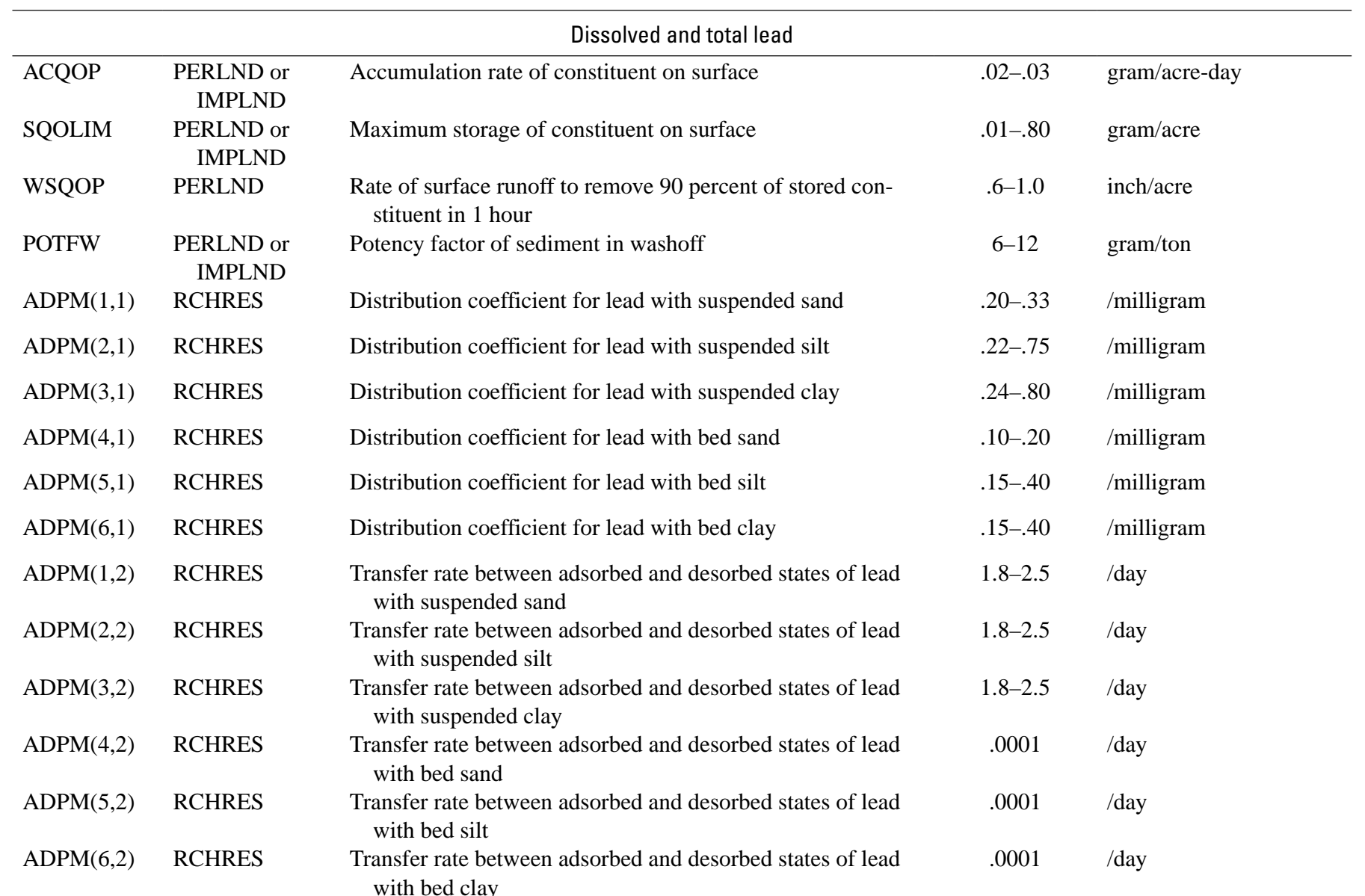


Table 16. Summary of calibrated values for selected water-quality parameters for the Hydrological Simulation Program—FORTRAN model of the Leon Creek watershed, Bexar County, Texas, 1997-2004-Continued.

\begin{tabular}{|c|c|c|c|c|}
\hline Parameter & Model module & Description & Value & Unit \\
\hline \multicolumn{5}{|c|}{ Dissolved and total zinc } \\
\hline ACQOP & $\begin{array}{l}\text { PERLND or } \\
\text { IMPLND }\end{array}$ & Accumulation rate of constituent on surface & $0.24-30$ & gram/acre-day \\
\hline SQOLIM & $\begin{array}{l}\text { PERLND or } \\
\text { IMPLND }\end{array}$ & Maximum storage of constituent on surface & $16-180$ & gram/acre \\
\hline WSQOP & PERLND & $\begin{array}{l}\text { Rate of surface runoff to remove } 90 \text { percent of stored con- } \\
\text { stituent in } 1 \text { hour }\end{array}$ & .6 & inch/acre \\
\hline POTFW & $\begin{array}{l}\text { PERLND or } \\
\text { IMPLND }\end{array}$ & Potency factor of sediment in washoff & $1.5-2.0$ & gram/ton \\
\hline $\operatorname{ADPM}(1,1)$ & RCHRES & Distribution coefficient for zinc with suspended sand & $.15-.20$ & /milligram \\
\hline $\operatorname{ADPM}(2,1)$ & RCHRES & Distribution coefficient for zinc with suspended silt & $.15-.22$ & /milligram \\
\hline $\operatorname{ADPM}(3,1)$ & RCHRES & Distribution coefficient for zinc with suspended clay & $.15-.24$ & /milligram \\
\hline $\operatorname{ADPM}(4,1)$ & RCHRES & Distribution coefficient for zinc with bed sand & $.15-.21$ & /milligram \\
\hline $\operatorname{ADPM}(5,1)$ & RCHRES & Distribution coefficient for zinc with bed silt & $.15-.21$ & /milligram \\
\hline $\operatorname{ADPM}(6,1)$ & RCHRES & Distribution coefficient for zinc with bed clay & $.15-.21$ & /milligram \\
\hline $\operatorname{ADPM}(1,2)$ & RCHRES & $\begin{array}{l}\text { Transfer rate between adsorbed and desorbed states of zinc } \\
\text { with suspended sand }\end{array}$ & 1.8 & /day \\
\hline $\operatorname{ADPM}(2,2)$ & RCHRES & $\begin{array}{l}\text { Transfer rate between adsorbed and desorbed states of zinc } \\
\text { with suspended silt }\end{array}$ & 1.8 & /day \\
\hline $\operatorname{ADPM}(3,2)$ & RCHRES & $\begin{array}{l}\text { Transfer rate between adsorbed and desorbed states of zinc } \\
\text { with suspended clay }\end{array}$ & 1.8 & /day \\
\hline $\operatorname{ADPM}(4,2)$ & RCHRES & $\begin{array}{l}\text { Transfer rate between adsorbed and desorbed states of zinc } \\
\text { with bed sand }\end{array}$ & .0001 & /day \\
\hline $\operatorname{ADPM}(5,2)$ & RCHRES & $\begin{array}{l}\text { Transfer rate between adsorbed and desorbed states of zinc } \\
\text { with bed silt }\end{array}$ & .0001 & /day \\
\hline $\operatorname{ADPM}(6,2)$ & RCHRES & $\begin{array}{l}\text { Transfer rate between adsorbed and desorbed states of zinc } \\
\text { with bed clay }\end{array}$ & .0001 & /day \\
\hline
\end{tabular}

2003 to 1.07 tons per acre in 2002, with an average yield of 0.34 ton per acre per year.

Annual streamflow loads of dissolved nitrate at the watershed outlet were relatively constant because the source of most of the dissolved nitrate load was discharge of wastewater, which is relatively constant compared to stormflow-dominated streamflows in the Leon Creek watershed. The wastewater discharge accounts for about 95 percent of the entire nitrate load in streamflow exiting the Leon Creek watershed. The average annual (1997-2004) streamflow load of dissolved nitrate at the outlet of the watershed was 802 tons per year. The corresponding yield was 10.5 pounds per acre per year.

Annual total lead load showed a correlation with streamflow, ranging from 1,260 pounds in 2003 to 11,000 pounds in 2002. The average annual load was 3,900 pounds per year. The corresponding annual total lead yields ranged from 0.008 pound per acre in 2003 to 0.072 pound per acre in 2002 , with an average annual yield of 0.026 pound per acre per year.
Mean annual yields of suspended sediment, dissolved nitrate, and total lead during 1997-2004 were simulated for six selected reach (RCHRES) outlets (table 18). The simulated reaches in table 18 are listed in order of increasing drainage area. The amount and effect of impervious area increase in the downstream direction. Suspended-sediment yields tend to decrease with distance downstream because the upstream part of the watershed includes more undeveloped land, which contributes larger sediment yields than more developed land. In the upstream part of the watershed (subwatershed 10 [RCHRES 10]), suspended-sediment yield averaged 0.56 ton per acre per year compared with an average of 0.34 ton per acre per year for the entire Leon Creek watershed (outlet of RCHRES 109).

Dissolved nitrate yield increases in the downstream direction. At the outlet of RCHRES 10, the yield was 0.20 pound per acre per year. Through the more developed midsection of the watershed, runoff yield gradually increases and was 0.46 pound per acre per year at the outlet of RCHRES 102. At the 
Table 17. Simulated mean annual streamflow and annual streamflow loads and yields of suspended sediment, dissolved nitrate nitrogen, and total lead at the outlet of Leon Creek watershed, Bexar County, Texas, 1997-2004.

$\left[\mathrm{ft}^{3} / \mathrm{s}\right.$, cubic feet per second]

\begin{tabular}{|c|c|c|c|c|c|c|c|}
\hline \multirow[b]{2}{*}{ Year or period } & \multirow{2}{*}{$\begin{array}{l}\text { Simulated } \\
\text { streamflow } \\
\left(\mathrm{ft}^{3} / \mathrm{s}\right)\end{array}$} & \multicolumn{2}{|c|}{ Simulated suspended sediment } & \multicolumn{2}{|c|}{$\begin{array}{c}\text { Simulated dissolved } \\
\text { nitrate nitrogen }\end{array}$} & \multicolumn{2}{|c|}{$\begin{array}{l}\text { Simulated } \\
\text { total lead }\end{array}$} \\
\hline & & $\begin{array}{l}\text { Load } \\
\text { (tons per } \\
\text { year) }\end{array}$ & $\begin{array}{c}\text { Yield } \\
\text { (tons per acre } \\
\text { per year) }^{1} \\
\end{array}$ & $\begin{array}{l}\text { Load } \\
\text { (tons per } \\
\text { year) }\end{array}$ & $\begin{array}{c}\text { Yield } \\
\text { (pounds per acre } \\
\text { per year) }^{1}\end{array}$ & $\begin{array}{c}\text { Load } \\
\text { (pounds per } \\
\text { year) }\end{array}$ & $\begin{array}{c}\text { Yield } \\
\text { (pounds per } \\
\text { acre per year) }{ }^{1}\end{array}$ \\
\hline 1997 & 90.4 & 33,600 & 0.22 & 790 & 10.4 & 3,050 & 0.020 \\
\hline 1998 & 145 & 111,000 & .73 & 825 & 10.8 & 5,690 & .037 \\
\hline 2000 & 76.2 & 19,500 & .13 & 770 & 10.1 & 2,590 & .017 \\
\hline 2001 & 77.3 & 29,700 & .20 & 810 & 10.6 & 2,640 & .017 \\
\hline 2002 & 393 & 163,000 & 1.07 & 860 & 11.3 & 11,000 & .072 \\
\hline
\end{tabular}

${ }^{1}$ Leon Creek drainage area upstream from outlet of watershed is 152,239 acres.

Table 18. Simulated mean annual streamflow and mean annual streamflow yields of suspended sediment, dissolved nitrate nitrogen, and total lead at selected stream reach (RCHRES) outlets, Leon Creek watershed, Bexar County, Texas, $1997-2004$.

$\left[\mathrm{ft}^{3} / \mathrm{s}\right.$, cubic feet per second]

\begin{tabular}{|c|c|c|c|c|c|}
\hline $\begin{array}{c}\text { Site } \\
\text { (fig. 5) }\end{array}$ & $\begin{array}{c}\text { Average simulated } \\
\text { streamflow } \\
\left(\mathrm{ft}^{3} / \mathbf{s}\right)\end{array}$ & $\begin{array}{l}\text { Drainage area } \\
\text { (acres) }\end{array}$ & $\begin{array}{l}\text { Simulated suspended- } \\
\text { sediment yield } \\
\text { (tons per acre } \\
\text { per year) }\end{array}$ & $\begin{array}{c}\text { Simulated dissolved } \\
\text { nitrate nitrogen } \\
\text { yield } \\
\text { (pounds per acre } \\
\text { per year) }\end{array}$ & $\begin{array}{c}\text { Simulated } \\
\text { total lead yield } \\
\text { (pounds per } \\
\text { acre per year) }\end{array}$ \\
\hline Outlet of RCHRES 10 & 5.2 & 6,875 & 0.56 & 0.20 & 0.008 \\
\hline Outlet of RCHRES 34 & 26 & 48,618 & .42 & .31 & .008 \\
\hline Outlet of RCHRES 98 & 100 & 133,424 & .29 & .43 & .017 \\
\hline Outlet of RCHRES 102 & 106 & 137,902 & .32 & .46 & .020 \\
\hline Outlet of RCHRES 109 & 175 & 152,239 & .34 & 10.5 & .026 \\
\hline
\end{tabular}

outlet of RCHRES 109, the yield increases appreciably to 10.5 pounds per acre per year because of the effect of the wastewater inflow.

Total lead yield also increased in the downstream direction, which is attributed to greater runoff yields for developed and impervious land, percentages of which increase in the downstream direction of the Leon Creek watershed. Total lead yield at the outlet of RCHRES 10 was 0.008 pound per acre per year compared with 0.026 pound per acre per year for the entire watershed (outlet of RCHRES 109).

\section{Model Limitations}

Errors in model calibration can be classified as either systematic or measurement errors (Raines, 1996). Systematic errors are associated with limitations of the model to 
represent the hydrologic processes of the watershed. As a result, there are limits to how well model parameters and equations represent the complex physical properties of streamflow and water-quality processes.

Measurement errors are introduced as a result of inaccurate or missing data. The degree to which available rainfall data represent actual rainfall is potentially the most serious source of measurement error. Although the NEXRAD rainfall data used for the study provide adequate spatial representation of rainfall, rainfall totals and intensity might not always be accurately represented. For example, NEXRAD rainfall used as input for the simulation model possibly underestimated actual rainfall during the storm of October 17-18, 1998. Streamflow volume at station 08181480 Leon Creek at IH 35 (site 15) during October 1998 was under-simulated by nearly 50 percent. Also, runoff from this storm contributed about 20 percent of the entire streamflow at station 08181480 during the 1997-2004 simulation period. Thus, errors in rainfall input for major events can have substantial effects on calibration and simulation results.

Overall, streamflow is simulated with reasonable accuracy at streamflow-gaging stations. At other sites, accuracy of streamflow simulation is uncertain. Streamflow characteristics, especially flow duration, are much different between the upstream and downstream gaging stations (figs. 6-8). No measured streamflow data are available in the stream reaches between the upper-watershed sites and the downstream station 08181480 Leon Creek at IH 35. The midsection of the watershed is an area of physical changes: changes from steeper to flatter slopes, changes in geology and soils, increase in development and impervious cover, and the merging of upper Leon Creek and Culebra Creek (fig. 1). Also, stream reaches immediately downstream from the confluence of upper Leon Creek and Culebra Creek (reaches 80, 84, 88, 92, and 96) (fig. 5) are susceptible to flash flooding. Continuous streamflow data in the area of reach 80 or 84 could improve model streamflow calibration.

Water-quality simulations also are affected by uncertainties in rainfall and streamflow. For example, overestimation of rainfall might result in simulated runoff and streamflow greater than actual. In turn, simulated suspended-sediment concentrations likely would be greater than actual. Simulated metals concentrations, because of close association of metals with sediment, also likely would be greater than actual.

Major storms contribute most of the streamflow and most of the streamflow loads for certain water-quality constituents. For example, the three largest stormflows (June 1997, October 1998, and July 2002) contributed about 64 percent of the entire suspended-sediment load at station 08181480 Leon Creek at IH 35 during 1997-2004; however, no water-quality samples were collected during these stormflows. Water-quality constituent calibration and simulation might be improved with sample data that better characterize water-quality conditions during major storms.

\section{Summary}

The U.S. Geological Survey (USGS), in cooperation with the U.S. Army Corps of Engineers (USACE) and the San Antonio River Authority, configured, calibrated, and tested a Hydrological Simulation Program-FORTRAN (HSPF) watershed model for the approximately 238-square-mile Leon Creek watershed in Bexar County, Texas, and used the model to simulate streamflow and water quality (focusing on loads and yields of selected constituents). The USGS cooperative study was a part of phase 1 of a larger USACE study to establish and document the existing hydrologic, engineering, economic, and environmental conditions for the watershed.

Streamflow in the model was calibrated and tested with available data from five USGS streamflow-gaging stations for the period 1997-2004. Streamflow data from four upperwatershed sites, where streamflows are intermittent, were used to calibrate model parameters for the subwatersheds upstream from the respective upper-watershed sites. The most downstream station, station 08181480 Leon Creek at Interstate Highway (IH) 35, was the primary source of data for streamflow calibration of subwatersheds downstream from the upper-watershed sites. Data from this perennial-flow station for 2001-04 were used for calibration. Data for 1997-2000 were used to test the calibrated model.

Simulated streamflow volumes closely matched measured streamflow volumes at all streamflow-gaging stations. Total simulated streamflow volumes were within 10 percent of measured values. Annual, monthly, and daily coefficients of determination of the linear regression between measured and simulated streamflow and Nash-Sutcliff coefficients of modelfit efficiency (NSE) are considered acceptable for all stations. The NSE for daily streamflow volumes ranged from .80 to .97 for the calibration periods at all stations. The NSE for hourly values for the entire 1997-2004 simulation period at the Leon Creek at IH 35 station was .70, which is considered good.

Streamflow volumes are greatly influenced by large storms. Two months that included major floods (October 1998 and July 2002) accounted for about 50 percent of all the streamflow measured at station 08181480 Leon Creek at IH 35 during 1997-2004.

Wastewater discharged from the large municipal treatment facility near the mouth of Leon Creek accounted for a substantial part of the total streamflow exiting the Leon Creek watershed during 1997-2004. The average recycled wastewater discharge was about 39,000 acre-feet per year compared with the average simulated total streamflow of about 127,000 acre-feet per year at the outlet of Leon Creek, or about 31 percent of the average simulated total streamflow.

The HSPF model was calibrated for selected waterquality properties and constituents using available data from 13 sites in and near the Leon Creek watershed for varying periods of record during 1992-2005. The model was used to simulate water temperature, dissolved oxygen, suspended sediment, dissolved ammonia nitrogen, dissolved nitrate nitrogen, and dissolved and total lead and zinc. Average simulated daily 
mean water temperature at station 08181480 Leon Creek at IH 35 during 1997-2000 was within 1 percent of average measured daily mean water temperature. NSE values for simulated water temperature were .89 for daily values and .83 for hourly values. Average simulated daily mean dissolved oxygen during 1997-2000 was within 1 percent of average measured daily mean dissolved oxygen. NSE values for simulated dissolved oxygen were .35 for daily values and .18 for hourly values.

Suspended-sediment data were available for seven sites in and near the watershed for 1992-2005. Soil-erosion and sediment-washoff parameters were calibrated by comparing simulated suspended-sediment concentrations to measured concentrations in runoff from four urban land-use types represented in the measured data. Parameters related to sediment transport were calibrated primarily by comparing simulated suspended-sediment concentrations and loads to computed concentrations and loads from measured data collected at three of the four upper-watershed sites during three stormflows in 2002 and 2004. From a regression relation between daily mean streamflow and daily suspended-sediment load at station 08181480 Leon Creek at IH 35 developed from 1992-97 measured data (coefficient of determination $=.869$ ), estimated daily sediment loads at that site were computed for 2001-04. These estimated daily sediment loads were used as targets for HSPF suspended-sediment calibration and simulations at station 08181480 Leon Creek at IH 35. The HSPF-simulated suspended-sediment load during 2001-04 (excluding July 2002 because of major storms) was 77,700 tons compared with an estimate of 74,600 tons from the streamflow-load relation (less than 5 percent difference).

Median concentrations of dissolved ammonia nitrogen and dissolved nitrate nitrogen from wet deposition (rainfall) data at Beeville and Sonora, Tex., were used as input rainfall concentrations for wet deposition onto the watershed for the HSPF simulations. Calibration to obtain related parameters was similar to that for soil-erosion and sediment-washoff parameters using measured nutrient data collected at three of the four upper-watershed sites during three stormflows in 2002 and 2004. Calibration of parameters related to nutrient simulations in the lower part of the watershed is based on very few measured data at station 08181480 Leon Creek at IH 35; however, simulated concentrations of dissolved ammonia nitrogen and dissolved nitrate nitrogen for two stormflows closely matched (within $0.1 \mathrm{mg} / \mathrm{L}$ ) measured concentrations. At station 08181480 Leon Creek at IH 35, average simulated monthly mean concentrations of dissolved ammonia and nitrate concentrations during 1997-2004 were 0.03 and $0.37 \mathrm{mg} / \mathrm{L}$, respectively. Because of the inflow of wastewater, the average simulated monthly mean concentration of nitrate at the most downstream reach during 1997-2004 was $7.4 \mathrm{mg} / \mathrm{L}$.

Analyses of stormflow samples collected at all five streamflow-gaging stations and base-flow samples collected at station 08181480 Leon Creek at IH 35 were available for calibrating with regard to dissolved and total lead and zinc.
Generally, simulated lead and zinc concentrations for stormflows compared adequately with measured concentrations at the upper-watershed sites. For example, the median measured total lead concentration in selected stormflows for 1997-2004 for the four upper-watershed sites was $2.9 \mu \mathrm{g} / \mathrm{L}$, and the median simulated concentration was $4.2 \mu \mathrm{g} / \mathrm{L}$. For station 08181480 Leon Creek at IH 35, the measured and simulated concentrations for stormflows match less closely. For example, the median measured total lead concentration for 1993-97 stormflow data is $6.5 \mu \mathrm{g} / \mathrm{L}$, and the median simulated total lead concentration for three 1997 stormflows is $14 \mu \mathrm{g} / \mathrm{L}$. For base-flow conditions during 1997-2004 at station 08181480 Leon Creek at IH 35, the simulated/measured concentrations match closely. For example, average and median simulated concentrations of total lead (for 2,041 days) were 1.3 and $0.96 \mu \mathrm{g} / \mathrm{L}$, respectively, and average and median measured concentrations (for nine samples) of total lead were less than 1.0 and $1.0 \mu \mathrm{g} / \mathrm{L}$, respectively.

To demonstrate an application of the Leon Creek HSPF model, streamflow constituent loads and yields for suspended sediment, dissolved nitrate nitrogen, and total lead were simulated at the mouth of Leon Creek (outlet of the watershed) for 1997-2004. The average suspended-sediment load was 51,800 tons per year. The average suspended-sediment yield was 0.34 ton per acre per year. The average load of dissolved nitrate at the outlet of the watershed was 802 tons per year. The corresponding yield was 10.5 pounds per acre per year. The average load of lead at the outlet was 3,900 pounds per year. The average lead yield was 0.026 pound per acre per year.

The degree to which available rainfall data represent actual rainfall is potentially the most serious source of measurement error associated with the Leon Creek model. Overall, streamflow is simulated with reasonable accuracy at streamflow-gaging stations. At other sites, accuracy of streamflow simulation is uncertain. Water-quality simulations also are affected by uncertainties in rainfall and streamflow. Major storms contribute most of the streamflow loads for certain constituents. For example, the three largest stormflows contributed about 64 percent of the entire suspended-sediment load at station 08181480 Leon Creek at IH 35 during 1997-2004. Water-quality constituent calibration and simulation might be improved with sample data that better characterize waterquality conditions during major storms.

\section{References}

Allison, J.D., and Allison, T.L., 2005, Partition coefficients for metals in surface water, soil, and waste: Washington, DC, U.S. Environmental Protection Agency, Office of Research and Development, $93 \mathrm{p}$.

Aqua Terra Consultants, 2007, Scenario generator for enhanced use of watershed models: accessed May 30, 2007, at http://www.aquaterra.com/genscn.html 
Asquith, W.H., and Roussel, M.C., 2003, Atlas of interoccurrence intervals of selected thresholds of daily precipitation in Texas: U.S. Geological Survey Water-Resources Investigations Report 03-4281, 106 p.

Bicknell, B.R., Imhoff, J.C., Kittle, J.L. Jr., Donigian, A.S., and Johanson, R.C., 2001, Hydrological Simulation Program-FORTRAN, user's manual for version 12: Research Triangle Park, N.C., U.S. Environmental Protection Agency, National Exposure Research Laboratory, Office of Research and Development, 843 p.

Bomar, G.W., 1995, Texas weather (2d ed.): Austin, University of Texas Press, 275 p.

Bowie, G.L., Mills, W.B., Porcella, D.B., Campbell, C.L., Pagenkopf, J.R., Rupp, G.L., Johnson, K.M., Chan, P., Gherini, S.A., and Chamberlin, C.E., 1985, Rates, constants, and kinetic formulations in surface water quality modeling ( $2 \mathrm{~d}$ ed.): Athens, Ga., U.S. Environmental Protection Agency, Environmental Research Laboratory, Office of Research and Development, EPA/600/3-85/040, 455 p.

Brown, D.S., and Raines, T.H., 2002, Simulation of flow and effects of best-management practices in the upper Seco Creek Basin, south-central Texas, 1991-98: U.S. Geological Survey Water-Resources Investigations Report 02-4249, $22 \mathrm{p}$.

Brown, T.E., Waechter, N.B., Rose, P.R., and Barnes, V.E., 1983, Geologic atlas of Texas, GA0029 San Antonio sheet: Austin, The University of Texas, Bureau of Economic Geology, 8 p., 1 sheet.

Childress, C.J.O., Foreman, W.T., Connor, B.F., and Maloney, T.J., 1999, New reporting procedures based on longterm method detection levels and some considerations for interpretations of water-quality data provided by the U.S. Geological Survey National Water Quality Laboratory: U.S. Geological Survey Open-File Report 99-103, 19 p.

City of San Antonio, Department of Public Works, 2006, Storm water utility: accessed November 14, 2007, at http://www.sanantonio.gov/publicworks/stormwater/.

Donigian, A.S., Jr., Bicknell, B.R., and Imhoff, J.C., 1995, Hydrological Simulation Program_FORTRAN (HSPF), in Singh, V.P., ed., Computer models of watershed hydrology: Highlands Ranch, Colo., Water Resources Publications, p. 395-442.

Donigian, A.S., Jr., Imhoff, J.C., Bicknell, B.R., and Kittle, J.L., Jr., 1984, Application guide for Hydrological Simulation Program-FORTRAN (HSPF): Athens, Ga., U.S. Environmental Protection Agency, Environmental Research Laboratory, EPA-600/3-84-065, 177 p.

Donigian, A.S., Jr., and Love, J.T., 2003, Sediment calibration procedures and guidelines for watershed modeling: accessed August 14, 2009, at http://www.hspf.com/pdf/ TMDL2003PaperDonigian.pdf
Gandara, S.C., Gibbons, W.J., Barbie, D.L., and Jones, R.E., 2000, Water resources data, Texas, water year 1999-Volume 5. Guadalupe River Basin, Nueces River Basin, Rio Grande Basin, and intervening coastal basins: U.S. Geological Survey Water-Data Report TX-99-05, 400 p.

Greene, D.G., and Hudlow, M.D., 1982, Hydrometeorologic grid mapping procedures, in Johnson, A.I., and Clark, R.A., American Water Resources Association International Symposium on Hydrometeorology, Denver, Colorado, June 13-17, 1982: Proceedings, 20 p.

Larkin, T.J., and Bomar, G.W., 1983, Climatic atlas of Texas: Texas Department of Water Resources Report LP-192, $151 \mathrm{p}$.

Lumb, A.M., McCammon, R.B., and Kittle, J.L. Jr., 1994, Users manual for an expert system (HSPEXP) for calibration of the Hydrological Simulation Program-FORTRAN: U.S. Geological Survey Water-Resources Investigations Report 94-4168, 102 p.

Maclay, R.W., 1995, Geology and hydrology of the Edwards aquifer in the San Antonio area, Texas: U.S. Geological Survey Water-Resources Investigations Report 95-4186, 64 p., 12 pl.

Martin G.R., Zarriello, P.J., and Shipp, A.A., 2001, Hydrologic and water-quality characterization and modeling of the Chenoweth Run Basin, Jefferson County, Kentucky: U.S. Geological Survey Water-Resources Investigations Report 00-4239, 197 p.

Nash, J.E., and Sutcliffe, J.V., 1970, River flow forecasting through conceptual models, part $1-\mathrm{A}$ discussion of principles: Journal of Hydrology, v. 10, p. 282-290.

National Atmospheric Deposition Program, 2006, National Research Support Project-3: Champaign, Ill., National Atmospheric Deposition Program Office, Illinois State Water Survey, accessed August 12, 2007, at http://nadp.sws. uiuc.edu/sites/ntnmap.asp? state $=$ tx

National Climatic Data Center, 2009, Comparative climatic data for the United States through 2008: Asheville, N.C., National Oceanic and Atmospheric Administration, National Environmental Satellite, Data and Information Service, accessed August 14, 2009, at http://www1.ncdc.noaa. gov/pub/data/ccd-data/CCD-2008.pdf

National Oceanic and Atmospheric Administration, 2006, NOAA hydrologic data systems group-ABRFC operational NEXRAD stage III data: accessed December 13, 2008, at http://dipper.nws.noaa.gov/hdsb/data/nexrad/ abrfc_stageiii.php

Ockerman, D.J., 2002, Simulation of runoff and recharge and estimation of constituent loads in runoff, Edwards aquifer recharge zone (outcrop) and catchment area, Bexar County, Texas, 1997-2000: U.S. Geological Survey WaterResources Investigations Report 02-4241, 31 p. 
Ockerman, D.J., 2005, Simulation of streamflow and estimation of recharge to the Edwards aquifer in the Hondo Creek, Verde Creek, and San Geronimo Creek watersheds, southcentral Texas, 1951-2003: U.S. Geological Survey Scientific Investigations Report 2005-5252, 37 p.

Ockerman, D.J., and McNamara, K.C., 2003, Simulation of streamflow and estimation of streamflow constituent loads in the San Antonio River watershed, Bexar County, Texas, 1997-2001: U.S. Geological Survey Water-Resources Investigations Report 03-4030, 37 p.

Paode, R.D., Sofuoglu, S.C., Sivadechathep, J., Noll, K.E., Holsen, T.M., and Keeler, G.J., 1998, Dry deposition fluxes and mass size distributions of $\mathrm{Pb}, \mathrm{Cu}$, and $\mathrm{Zn}$ measured in southern Lake Michigan during AEOLOS: Environmental Science \& Technology, v. 32, no. 11, p. 1,629-1,635.

Puente, Celso, 1978, Method of estimating natural recharge to the Edwards aquifer in the San Antonio area, Texas: U.S. Geological Survey Water-Resources Investigations Report 78-10, 34 p.

Raines, T.H., 1996, Simulation of storm peaks and storm volumes for selected subbasins in the West Fork Trinity River Basin, Texas, water years 1993-94: U.S. Geological Survey Water-Resources Investigations Report 96-4110, 41 p.

Shedd, R.C., and Fulton, R.A., 1993, WSR-88D Precipitation processing and its use in National Weather Service hydrologic forecasting, in International Symposium on Engineering Hydrology, San Francisco, California, July 25-29, 1993, Proceedings: American Society of Civil Engineers, p. 16-21.

Singh, V.P., 1995, Watershed modeling, in Singh, V.P., ed., Computer models of watershed hydrology: Highlands Ranch, Colo., Water Resources Publications, p. 1-22.

Slade, R.M., Jr., and Patton, John, 2003, Major and catastrophic storms and floods in Texas: U.S. Geological Survey Open-File Report 03-193, 1 CD-ROM.

Slade, R.M., Jr., and Persky, Kristie, 1999, Floods in the Guadalupe and San Antonio River Basins in Texas: U.S. Geological Survey Fact Sheet 147-99, 4 p.

Texas Commission on Environmental Quality, 2002, Texas water quality inventory 2000 (SFR-050/00): accessed November 15, 2007, at http://www.tceq.state.tx.us/assets/ public/comm_exec/pubs/sfr/050_00/index.html
Texas Commission on Environmental Quality, 2005, 2004 Texas water quality inventory and 303(d) list: accessed November 15, 2007, at http://www.tceq.state.tx.us/ compliance/monitoring/water/quality/data/04twqi/ twqi04.html

Texas Department of State Health Services, 2008, Bexar County health facts for 2004 and 1997: accessed December 12, 2008, at http://www.dshs.state.tx.us/chs/cfs/.

U.S. Army Corps of Engineers, 2004, Project management plan, Leon Creek watershed, Texas-Interim feasibillity study, Guadalupe-San Antonio River Basin, Texas: U.S. Army Corps of Engineers, Fort Worth District, 28 p.

U.S. Department of Agriculture, Soil Conservation Service [Natural Resources Conservation Service], 1966, Soil survey of Bexar County, Texas: Soil Conservation Service, 126 p., 88 map sheets.

U.S. Environmental Protection Agency, 2006, Sediment parameter and calibration guidance for HSPF: U.S. Environmental Protection Agency, EPA BASINS Technical Note 8, accessed April 28, 2008, at http://www.epa.gov/ waterscience/BASINS/docs/tecnot8.pdf

U.S. Environmental Protection Agency, 2008, Better assessment science integrating point and nonpoint sources (BASINS): accessed December 13, 2008, at http://www.epa. gov/OST/BASINS/.

U.S. Geological Survey, 2001, Rocky Mountain Mapping Center-Elevation program: accessed December 15, 2004, at http://rockyweb.cr.usgs.gov/elevation/.

U.S. Geological Survey, 2009, National Water Information System (NWISWeb) data available on the World Wide Web: at http://waterdata.usgs.gov/tx/nwis/nwis

Wicklein, S.M., and Schiffer, D.M., 2002, Simulation of runoff and water quality for 1990 and 2008 land-use conditions in the Reedy Creek watershed, east-central Florida: U.S. Geological Survey Water-Resources Investigations Report 02-4018, 62 p.

Zarriello, P.J., and Ries, K.G., III, 2000, A precipitation-runoff model for analysis of the effects of water withdrawals on streamflow, Ipswich River Basin, Massachusetts: U.S. Geological Survey Water-Resources Investigations Report 00-4029, 99 p. 
Blank Page 


\section{Appendix 1-Hydrological Simulation Program-FORTRAN (HSPF) process-related parameters used to simulate the Leon Creek watershed, Bexar County, Texas}


Blank Page 
Appendix 1. Hydrological Simulation Program-FORTRAN (HSPF) process-related parameters used to simulate the Leon Creek watershed, Bexar County, Texas.

[--, none; ${ }^{\circ} \mathrm{C}$, degrees Celsius; BOD, biochemical oxygen demand]

\section{Pervious Land (PERLND)}

\begin{tabular}{|c|c|c|c|}
\hline $\begin{array}{c}\text { Secondary } \\
\text { module }\end{array}$ & Parameter & Unit & Description \\
\hline
\end{tabular}

Water balance

Interception storage

PWATER

CEPSC inch

CEPS inch

Surface and subsurface storages

$\begin{array}{ll}\text { UZSN } & \text { inch } \\ \text { LZSN } & \text { inch } \\ \text { SURS } & \text { inch } \\ \text { IFWS } & \text { inch } \\ \text { UZS } & \text { inch } \\ \text { LZS } & \text { inch } \\ \text { AGWS } & \text { inch }\end{array}$

\section{Evapotranspiration}

LZETP

AGWETP

BASETP

Recession rates

$\begin{array}{ll}\text { KVARY } & 1 / \text { inch } \\ \text { AGWRC } & 1 / \text { day } \\ \text { IRC } & 1 / \text { day } \\ \text { GWVS } & \text { inch }\end{array}$

\section{Infiltration}

INFILT inch/hour
INFILD
INFEXP
INTFW

Interception storage capacity

Initial interception storage

Upper-zone nominal storage; an index to amount of depression and surface-layer storage of a pervious area

Lower-zone nominal storage; an index to soil-moisture-holding capacity

Initial surface storage

Initial interflow storage

Initial upper-zone storage

Initial lower-zone storage

Initial active-groundwater storage

Lower-zone evapotranspiration; an index to the density of deep-rooted vegetation on a pervious area

Fraction of available potential evapotranspiration demand that can be met with active groundwater

Fraction of available potential evapotranspiration demand that can be met with baseflow (groundwater outflow)

Groundwater outflow modifier; an index of how much effect recent recharge has on groundwater outflow

Basic groundwater recession rate if KVARY is zero and there is no inflow to groundwater

Interflow recession coefficient

Index to groundwater slope

Index to infiltration capacity of soil

Ratio of maximum to mean infiltration rate of a pervious area

Infiltration equation exponent

Index to amount of water that infiltrates and flows as interflow (shallow subsurface runoff)

Fraction of groundwater inflow to deep recharge 
Appendix 1. Hydrological Simulation Program-FORTRAN (HSPF) process-related parameters used to simulate the Leon Creek watershed, Bexar County, Texas-Continued.

\section{Pervious Land (PERLND)—Continued}

\begin{tabular}{|c|c|c|c|}
\hline $\begin{array}{l}\text { Secondary } \\
\text { module }\end{array}$ & Parameter & Unit & Description \\
\hline \multicolumn{4}{|r|}{ Water balance-Continued } \\
\hline & LSUR & foot & Average length of overland-flow plane \\
\hline & SLSUR & -- & Average slope of overland-flow plane \\
\hline \multicolumn{4}{|r|}{ Soil erosion } \\
\hline \multirow[t]{6}{*}{ SEDMNT } & SMPF & -- & Management factor to account for use of erosion-control factors \\
\hline & KRER & complex & Coefficient of soil-detachment equation \\
\hline & NVSI & pound/acre-day & Rate at which sediment enters detached-sediment storage from atmosphere \\
\hline & KSER & complex & Coefficient of detached-sediment washoff equation \\
\hline & JSER & complex & Exponent of detached-sediment washoff equation \\
\hline & \multicolumn{3}{|r|}{ Water-quality constituent flux } \\
\hline \multirow[t]{5}{*}{ PQUAL } & SQO & $\begin{array}{l}\text { pound/acre } \\
\text { (or gram/acre) }\end{array}$ & Initial constituent storage on surface \\
\hline & POTFW & $\begin{array}{l}\text { pound/ton } \\
\text { (or gram/ton) }\end{array}$ & Potency factor of sediment in washoff \\
\hline & WSQOP & inch/hour & Rate of surface runoff to remove 90 percent of stored constituent in 1 hour \\
\hline & IDOXP & milligram/liter & Concentration of dissolved oxygen in interflow \\
\hline & ADOXP & milligram/liter & Concentration of dissolved oxygen in base flow \\
\hline
\end{tabular}


Appendix 1. Hydrological Simulation Program-FORTRAN (HSPF) process-related parameters used to simulate the Leon Creek watershed, Bexar County, Texas-Continued.

\section{Impervious Land (IMPLND)}

\begin{tabular}{|c|c|c|c|}
\hline $\begin{array}{c}\text { Secondary } \\
\text { module }\end{array}$ & Parameter & Unit & Description \\
\hline \multicolumn{4}{|r|}{ Water balance } \\
\hline \multirow[t]{6}{*}{ IWATER } & LSUR & foot & Average length of overland-flow plane \\
\hline & SLSUR & -- & Average slope of overland-flow plane \\
\hline & NSUR & -- & Average roughness coefficient of overland-flow plane \\
\hline & RETSC & inch & Retention storage capacity of impervious areas \\
\hline & RETS & inch & Initial retention storage \\
\hline & SURS & inch & Initial overland-flow storage \\
\hline \multicolumn{4}{|r|}{ Sediment washoff } \\
\hline \multirow[t]{5}{*}{ SOLIDS } & KEIM & complex & Coefficient of solids washoff equation \\
\hline & JEIM & complex & Exponent of solids washoff equation \\
\hline & REMSDP & $1 /$ day & Fraction of solids removed on each day without runoff \\
\hline & ACCSDM & ton/acre-day & Solids accumulation rate \\
\hline & SLDS & ton/acre & Initial storage of solids \\
\hline \multicolumn{4}{|r|}{ Water-quality constituent flux } \\
\hline \multirow[t]{5}{*}{ IQUAL } & SQO & $\begin{array}{l}\text { pound/acre } \\
\quad \text { (or gram/acre) }\end{array}$ & Initial constituent storage on surface \\
\hline & POTFW & $\begin{array}{l}\text { pound/ton } \\
\text { (or gram/ton) }\end{array}$ & Potency factor of sediment in washoff \\
\hline & ACQOP & $\begin{array}{l}\text { pound/acre-day } \\
\quad \text { (or gram/acre-day) }\end{array}$ & Accumulation rate of constituent on surface \\
\hline & SQOLIM & $\begin{array}{l}\text { pound/acre } \\
\quad \text { (or gram/acre) }\end{array}$ & Maximum storage of constituent on surface \\
\hline & WSQOP & inch/hour & Rate of surface runoff to remove 90 percent of stored constituent in 1 hour \\
\hline
\end{tabular}


Appendix 1. Hydrological Simulation Program-FORTRAN (HSPF) process-related parameters used to simulate the Leon Creek watershed, Bexar County, Texas-Continued.

\section{Stream Reaches (RCHRES)}

\begin{tabular}{|c|c|c|c|}
\hline $\begin{array}{l}\text { Secondary } \\
\text { module }\end{array}$ & Parameter & Unit & Description \\
\hline \multicolumn{4}{|c|}{ Water balance } \\
\hline \multirow{4}{*}{ HYDR } & LEN & mile & Length of stream reach \\
\hline & STCOR & foot & Correction in reach depth to calculate stage \\
\hline & $\mathrm{KS}$ & -- & Weighting factor for flow routing \\
\hline & DB50 & millimeter & Median diameter of bed sediment \\
\hline ADCALC & CRRAT & -- & $\begin{array}{l}\text { Ratio of maximum velocity to mean velocity in reach cross section under } \\
\text { typical flow conditions }\end{array}$ \\
\hline \multirow{4}{*}{ HTRCH } & CFSAEX & -- & $\begin{array}{l}\text { Correction factor for solar radiation; the fraction of RCHRES exposed to } \\
\text { radiation }\end{array}$ \\
\hline & KATRAD & -- & Longwave radiation coefficient \\
\hline & $\mathrm{KCON}$ & -- & Conduction-convection heat transport coefficient \\
\hline & KEVAP & -- & Evaporation coefficient \\
\hline \multicolumn{4}{|c|}{ Dissolved oxygen and nutrient balance } \\
\hline \multirow[t]{3}{*}{ OXRX } & KBOD20 & /hour & Unit BOD decay rate at $20^{\circ} \mathrm{C}$ \\
\hline & KODSET & foot/hour & Rate of BOD settling \\
\hline & EXPREL & -- & Exponent in dissolved oxygen term of benthal BOD release equation \\
\hline \multirow[t]{3}{*}{ NUTRX } & KTAM20 & /hour & Nitrification rate of ammonia at $20^{\circ} \mathrm{C}$ \\
\hline & $\mathrm{KNO} 220$ & /hour & Nitrification rate of nitrite at $20^{\circ} \mathrm{C}$ \\
\hline & KNO320 & /hour & Denitrification rate of nitrate at $20^{\circ} \mathrm{C}$ \\
\hline \multicolumn{4}{|c|}{ Sediment transport } \\
\hline \multirow[t]{6}{*}{ SEDTRN } & BEDWID & foot & Width of streambed \\
\hline & BEDWRN & foot & Depth of streambed \\
\hline & POR & -- & Porosity of streambed \\
\hline & $\mathrm{D}$ & inch & Effective diameter of sediment particle \\
\hline & W & inch/second & Settling velocity of sediment particle in still water \\
\hline & RHO & gram/cubic centimeter & Density of sediment particle \\
\hline
\end{tabular}


Appendix 1. Hydrological Simulation Program-FORTRAN (HSPF) process-related parameters used to simulate the Leon Creek watershed, Bexar County, Texas-Continued.

\section{Stream Reaches (RCHRES)—Continued}

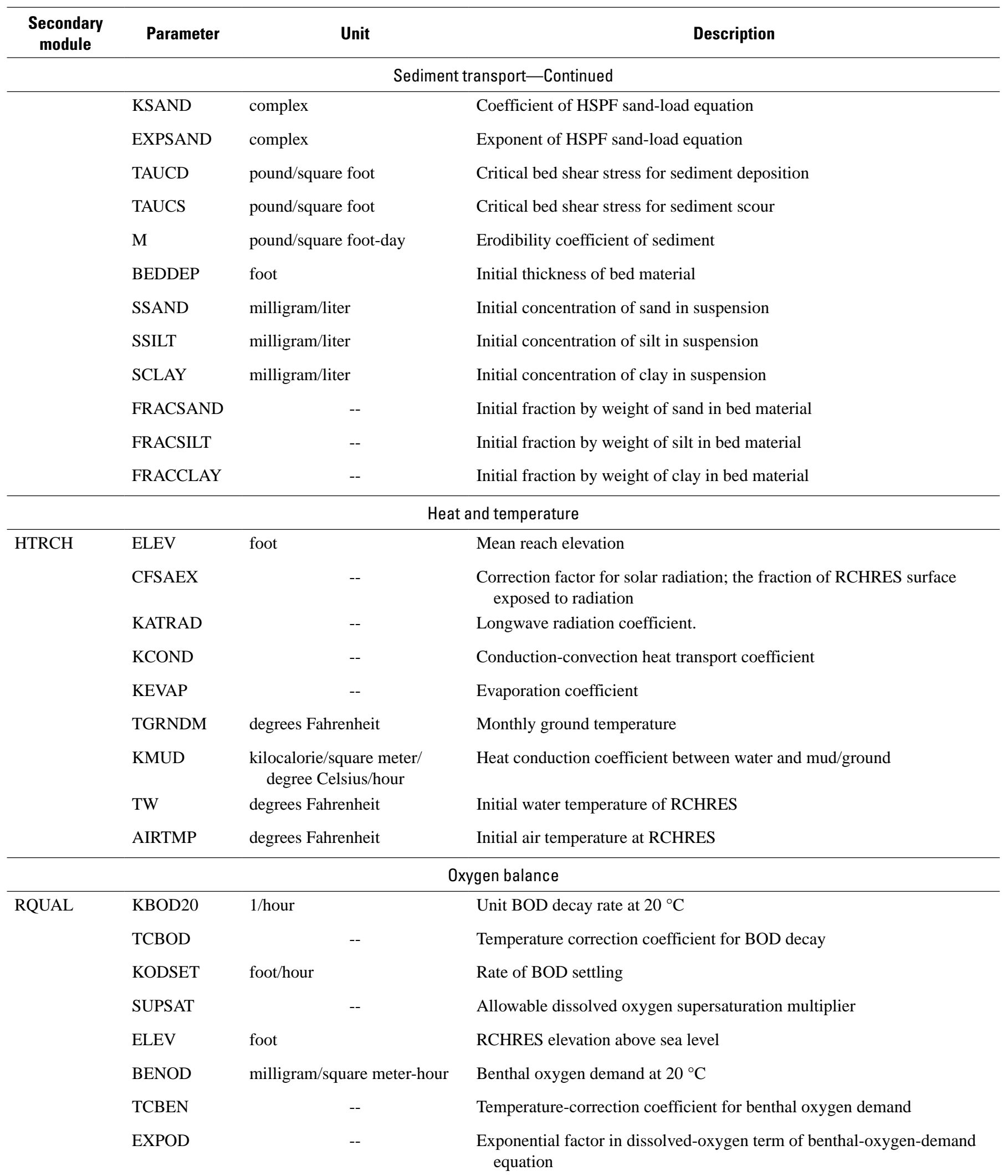


Appendix 1. Hydrological Simulation Program-FORTRAN (HSPF) process-related parameters used to simulate the Leon Creek watershed, Bexar County, Texas-Continued.

\section{Stream Reaches (RCHRES)—Continued}

\begin{tabular}{|c|c|c|c|}
\hline $\begin{array}{l}\text { Secondary } \\
\text { module }\end{array}$ & Parameter & Unit & Description \\
\hline \multicolumn{4}{|c|}{ Oxygen balance-Continued } \\
\hline & $\operatorname{BRBOD}(2)$ & milligram/square meter-hour & Increment to benthal release of BOD under anaerobic conditions \\
\hline & EXPREL & -- & $\begin{array}{l}\text { Exponential factor in dissolved oxygen term of benthal oxygen release } \\
\text { equation }\end{array}$ \\
\hline & TCGINV & -- & Temperature correction coefficient for surface-gas invasion \\
\hline & DOX & milligram/liter & Initial dissolved oxygen concentration \\
\hline & BOD & milligram/liter & Initial BOD concentration \\
\hline & SATDO & milligram/liter & Initial dissolved oxygen-saturation concentration \\
\hline \multicolumn{4}{|c|}{ Water-quality constituent balance-Nutrients } \\
\hline \multirow{7}{*}{ RQUAL } & KNO220 & $1 /$ hour & Nitrification rate of nitrite at $20^{\circ} \mathrm{C}$ \\
\hline & KNO320 & $1 /$ hour & Denitrification rate of nitrate at $20^{\circ} \mathrm{C}$ \\
\hline & TCNIT & -- & Temperature correction coefficient for nitrification \\
\hline & TCDEN & -- & Temperature correction coefficient for denitrification \\
\hline & DENOXT & milligram/liter & Dissolved oxygen concentration threshold for denitrification \\
\hline & $\begin{array}{l}\text { NO3, TAM, } \\
\text { NO2 }\end{array}$ & milligram/liter & Initial concentrations of nitrate, total ammonia, and nitrite \\
\hline & \multicolumn{3}{|c|}{ Water-quality constituent balance-Metals } \\
\hline & $\operatorname{ADPM}(5,1)$ & /milligram & Distribution coefficient for constituent with bed silt \\
\hline & $\operatorname{ADPM}(6,1)$ & /milligram & Distribution coefficient for constituent with bed clay \\
\hline & $\operatorname{ADPM}(1,2)$ & /day & $\begin{array}{l}\text { Transfer rate between adsorbed and desorbed states of constituent with } \\
\text { suspended sand }\end{array}$ \\
\hline & $\operatorname{ADPM}(2,2)$ & /day & $\begin{array}{l}\text { Transfer rate between adsorbed and desorbed states of constituent with } \\
\text { suspended silt }\end{array}$ \\
\hline & $\operatorname{ADPM}(3,2)$ & /day & $\begin{array}{l}\text { Transfer rate between adsorbed and desorbed states of constituent with } \\
\text { suspended clay }\end{array}$ \\
\hline & $\operatorname{ADPM}(4,2)$ & /day & $\begin{array}{l}\text { Transfer rate between adsorbed and desorbed states of constituent with } \\
\text { bed sand }\end{array}$ \\
\hline & $\operatorname{ADPM}(5,2)$ & /day & $\begin{array}{l}\text { Transfer rate between adsorbed and desorbed states of constituent with } \\
\text { bed silt }\end{array}$ \\
\hline & $\operatorname{ADPM}(6,2)$ & /day & $\begin{array}{l}\text { Transfer rate between adsorbed and desorbed states of constituent with } \\
\text { bed clay }\end{array}$ \\
\hline
\end{tabular}


Publishing support provided by Lafayette Publishing Service Center

Information regarding water resources in Texas is available at http://tx.usgs.gov/ 
